Florida International University FIU Digital Commons

6-18-2010

\title{
How Do Partnerships Lead to a Competitive Advantage? Applying the Resource Based View to Nascent Social Ventures
}

Moriah A. Meyskens

Florida International University, mmeyskens@gmail.com

DOI: $10.25148 /$ etd.FI10080408

Follow this and additional works at: https://digitalcommons.fiu.edu/etd

\section{Recommended Citation}

Meyskens, Moriah A., "How Do Partnerships Lead to a Competitive Advantage? Applying the Resource Based View to Nascent Social Ventures" (2010). FIU Electronic Theses and Dissertations. 238.

https://digitalcommons.fiu.edu/etd/238 


\title{
FLORIDA INTERNATIONAL UNIVERSITY \\ Miami, Florida
}

HOW DO PARTNERSHIPS LEAD TO A COMPETITIVE ADVANTAGE?

APPLYING THE RESOURCE BASED VIEW TO NASCENT SOCIAL VENTURES

\author{
A dissertation submitted in partial fulfillment of the \\ requirements for the degree of \\ DOCTOR OF PHILOSOPHY \\ in \\ BUSINESS ADMINISTRATION
}

by

Moriah Aurora Meyskens

2010 
To: Dean Joyce Elam

College of Business Administration

This dissertation, written by Moriah Aurora Meyskens, and entitled How Do Partnerships Lead to a Competitive Advantage? Applying the Resource Based View to Nascent Social Ventures, having been approved in respect to style and intellectual content, is referred to you for judgment.

We have read this dissertation and recommend that it be approved.

Alan Carsrud

Karen Paul

Mary Ann Von Glinow

Kenneth Lipartito

Date of Defense: June 18, 2010

Sumit Kundu, Major Professor

The dissertation of Moriah Aurora Meyskens is approved.

Dean Joyce Elam

College of Business Administration

Interim Dean Kevin O'Shea

University Graduate School

Florida International University, 2010 


\section{DEDICATION}

Dedicated to my husband, Dany, who makes everything more fun, and every day

a magical event. You make the journey of life an exciting adventure! Siempre te voy a hacer café y darte una docena en la mañana! 


\section{ACKNOWLEDGMENTS}

I would like to thank some of the individuals who played a key role in the completion of this dissertation and to my Ph.D. process as a whole.

To my external co-chair and advisor, Dr. Alan Carsrud, thank you for your continual support, guidance, and commitment to my development as a scholar and as a member of the entrepreneurship community. I greatly appreciate your tireless efforts and patient encouragement in training me to become a successful academic. You showed me how to make my ideas relevant, taught me the ins and outs of research, and I am grateful that through the years you have become a wonderful colleague and friend. To my co-chair, Dr. Sumit Kundu, thank you for your constant support and guidance throughout the doctoral process and the dissertation. To Dr. Kundu and my committee members, Drs. Karen Paul, Mary Ann Von Glinow, and Kenneth Lipartito, thank you for your insight and support through the past four years. I am extremely appreciative of your valuable lessons, and the depth of your comments for the dissertation and for the other projects in corporate social responsibility and international business in which we have engaged. Thank you Alan, Sumit, Karen, Mary Ann, and Ken for all your support and mentoring in every way! I look forward to working with all of you on research projects in the future.

To Drs. Paul Reynolds, Aya Chacar, William Schneper, William Newbury, Galen Kroeck, Jim Jaccard, Juan Sanchez, Candy Brush, Miguel Rivera, and Elaine Allen thank you for your encouragement, and inspiration - you've taught me important lessons about management research and made the $\mathrm{PhD}$ more interesting. To Dr. Paulette Johnson thank you for your continual support with statistical analysis through numerous classes, research projects, and the dissertation. To my fellow Phd students and their families - you 
made the Phd more enjoyable and fun! To Mark Adkins, thank you for your research support and continual interest in social ventures. To the Management and $\mathrm{PhD}$ program offices - Cris, Cassandra, Rosa and Sarah - thank you for your help through the years. To the countless individuals who participated in my dissertation through interviews, surveys, or informal discussions - thank you for your time and interest in my research! To FIU, FIU CIBER, GSA, the Pino Center, and the Kauffman Foundation, thank you for your financial support.

Finally, I would like to thank my family and friends who supported me throughout this journey and constantly encouraged me to follow my dreams and showered me with strength, inspiration and love. I love you all very much! To my criança husband Dany, thanks for always encouraging me to go forward, be patient, keep my butt in the chair, and continue the ride so that I can have as many degrees as you. To my dear siblings - Desy and Velli - I feel so lucky you are in my life - you are both so fun and caring. To my parents - Mom, Dad, and Linda - you are the rocks that provide unconditional love and support throughout life's many twists and turns. Thank you for always believing in me! To my immediate family gained through love and marriage Facu, Lucio, Cindy, Marta, Isidoro, Carina, Ariel, Ariela, and Tomy - I offer my profoundest appreciation for your support, and interest in what I was doing. To my extended family and friends who provided inspiration and support - you make the journey worthwhile and fun! There is not enough space to thank everyone who has played a part in my Ph.D. process. For those omitted in name, please accept my profoundest gratitude for your participation in my Ph.D. - it's been an enjoyable ride, and I thank everyone who has played a part in it. 


\begin{abstract}
OF THE DISSERTATION
HOW DO PARTNERSHIPS LEAD TO A COMPETITIVE ADVANTAGE?

APPLYING THE RESOURCE BASED VIEW TO NASCENT SOCIAL VENTURES
\end{abstract}

by

Moriah Aurora Meyskens

Florida International University, 2010

Miami, Florida

Professor Sumit Kundu, Major Professor

This dissertation is one of the earliest to systematically apply and empirically test the resource-based view (RBV) in the context of nascent social ventures in a large scale study. Social ventures are entrepreneurial ventures organized as nonprofit, for-profit, or hybrid organizations whose primary purpose is to address unmet social needs and create social value. Nascent social ventures face resource gaps and engage in partnerships or alliances as one means to access external resources. These partnerships with different sectors facilitate social venture innovative and earned income strategies, and assist in the development of adequate heterogeneous resource conditions that impact competitive advantage. Competitive advantage in the context of nascent social ventures is achieved through the creation of value and the achievement of venture development activities and launching. The relationships between partnerships, heterogeneous resource conditions, strategies, and competitive advantage are analyzed in the context of nascent social ventures that participated in business plan competitions. A content analysis of 179 social venture business plans and an exploratory follow-up survey of 72 of these ventures are 
used to analyze these relationships using regression, ANOVA, correlations, t-tests, and non-parametric statistics.

The findings suggest a significant positive relationship between competitive advantage and partnership diversity, heterogeneous resource conditions, social innovation, and earned income. Social capital is the type of resource most significantly related to competitive advantage. Founder previous start-up experience, client location, and business plan completeness are also found to be significant in the relationship between partnership diversity and competitive advantage. Finally the findings suggest that hybrid social ventures create a greater competitive advantage than nonprofit or forprofit social ventures. Consequently, this dissertation not only provides academics further insight into the factors that impact nascent social value creation, venture development, and ability to launch, but also offers practitioners guidance on how best to organize certain processes to create a competitive advantage. As a result more insight is gained into the nascent social venture creation process and how these ventures can have a greater impact on society. 


\section{TABLE OF CONTENTS}

CHAPTER

PAGE

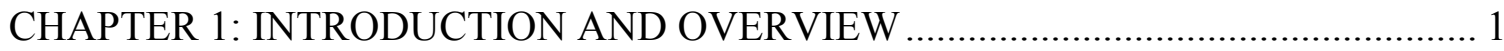

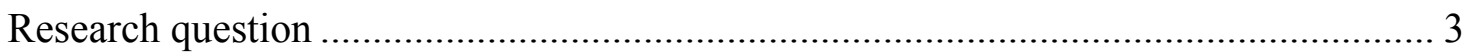

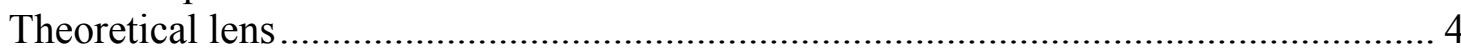

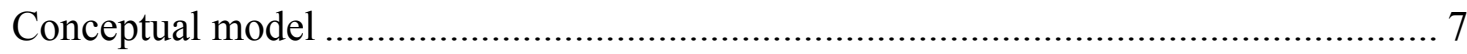

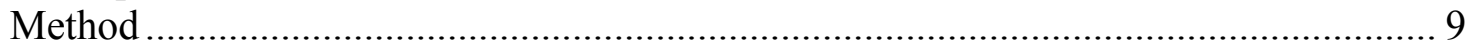

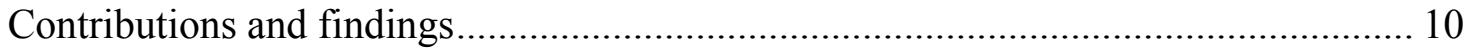

Dissertation format.......................................................................................... 13

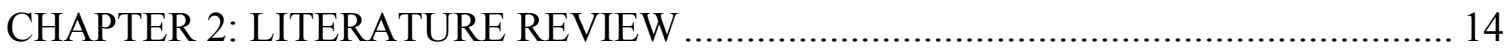

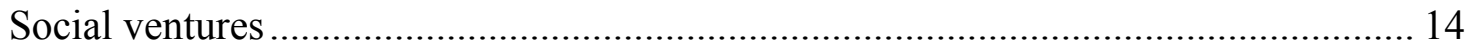

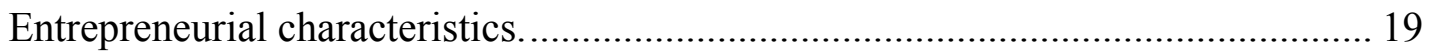

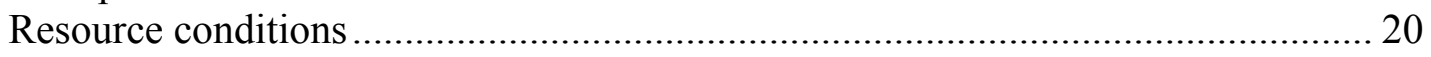

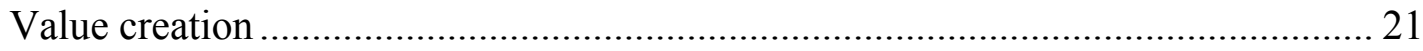

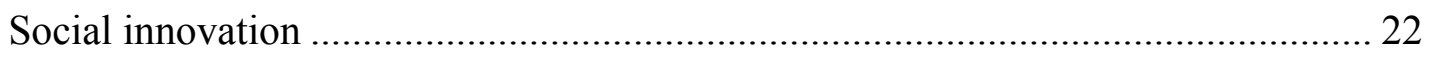

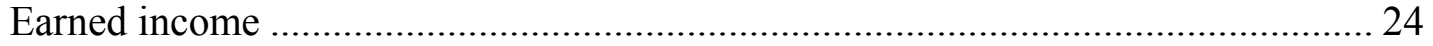

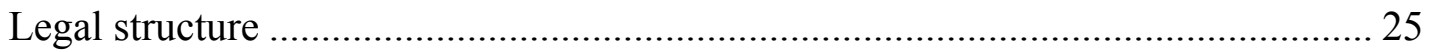

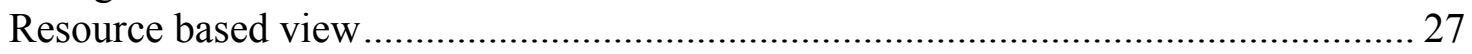

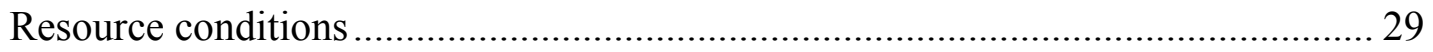

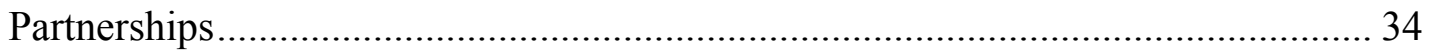

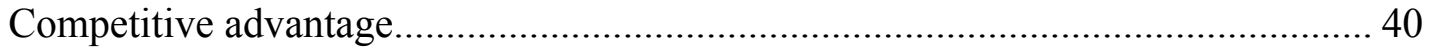

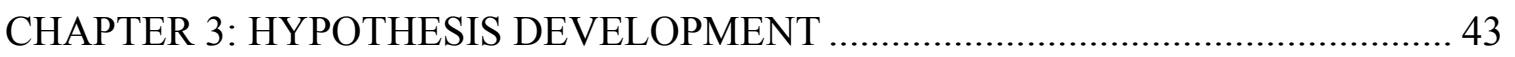

Social ventures, partnerships, resource conditions, and competitive advantage ......... 43

Partnerships, resources conditions, and competitive advantage ............................. 46

Partnerships, strategies, and competitive advantage ............................................. 51

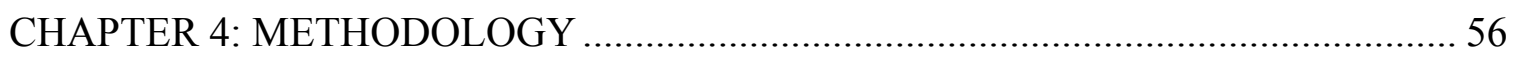

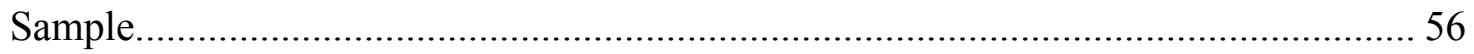

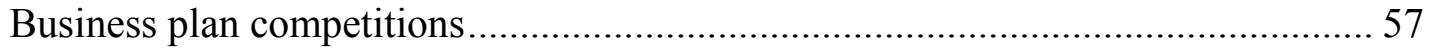

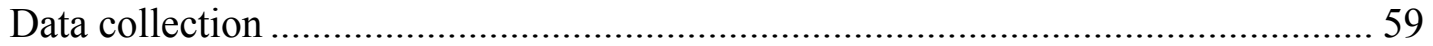

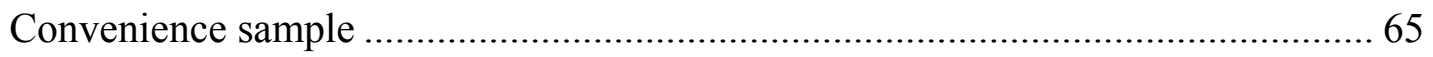

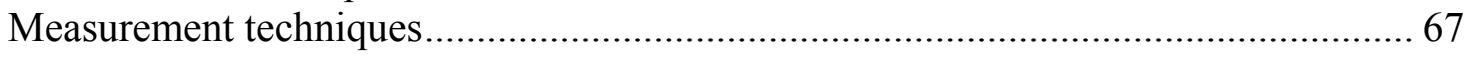

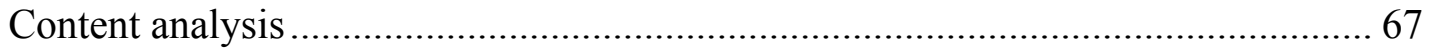

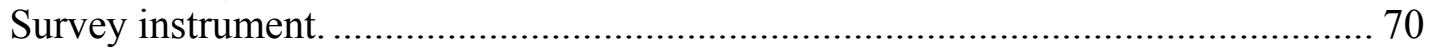

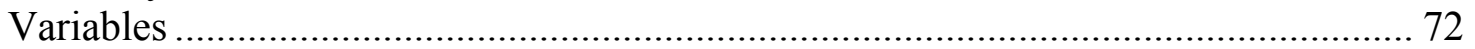

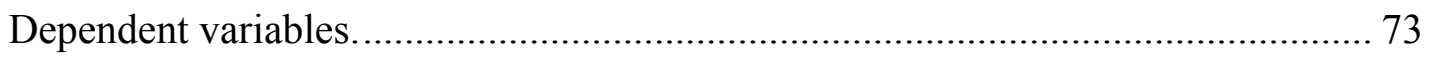

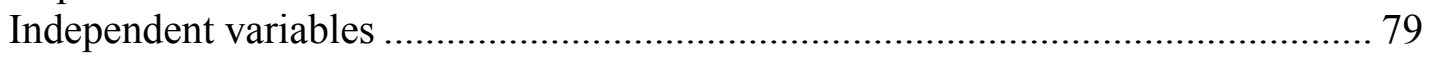

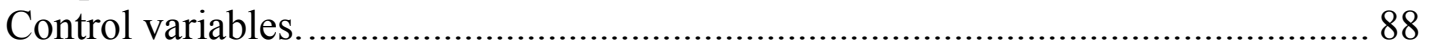

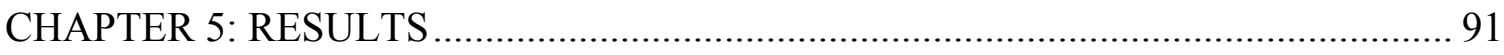

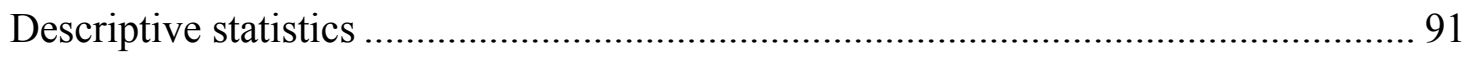




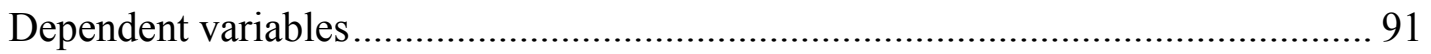

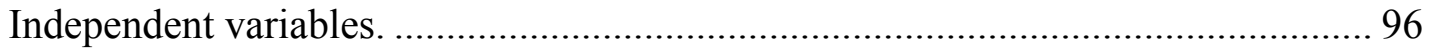

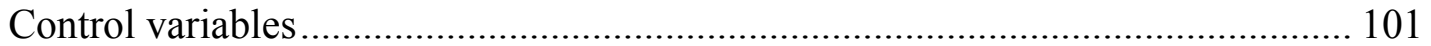

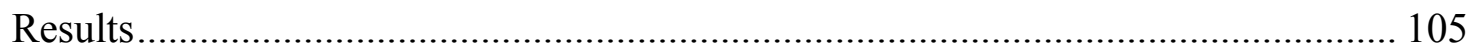

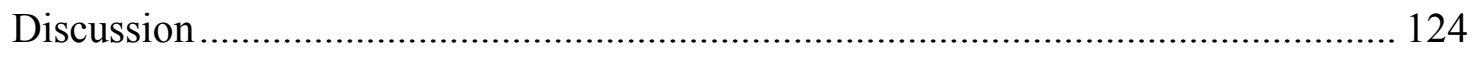

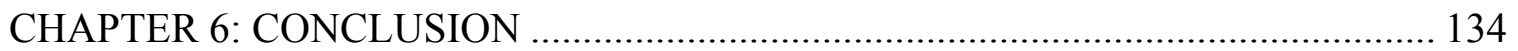

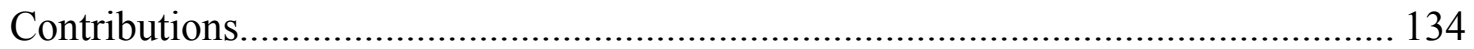

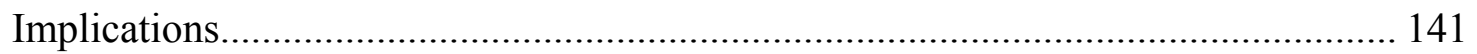

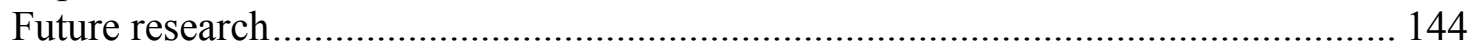

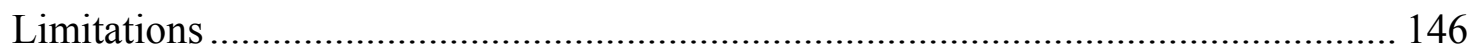

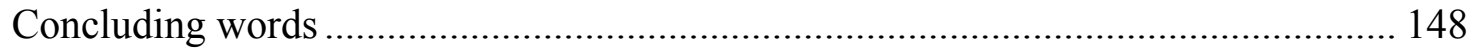

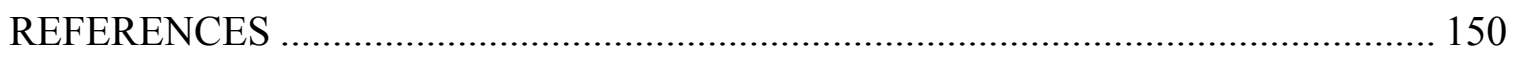

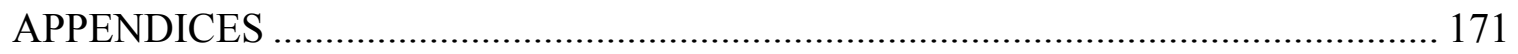

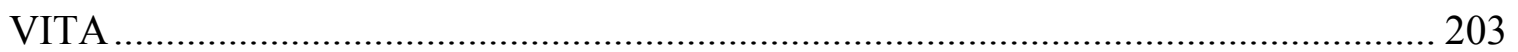




\section{LIST OF TABLES}

TABLE

PAGE

Table 1: Social venture characteristics and strategies.............................................. 17

Table 2: Social venture business plan competition sponsors - Not relevant ................... 60

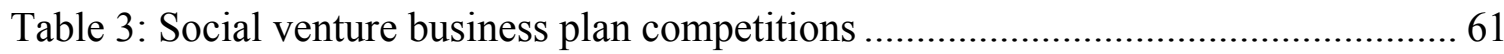

Table 4: Social venture business plan competition sponsors - Relevant........................ 62

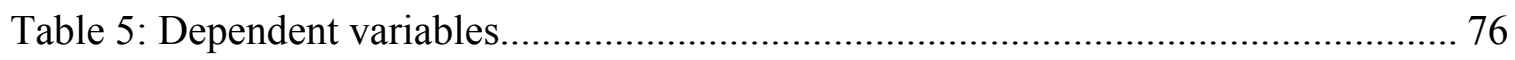

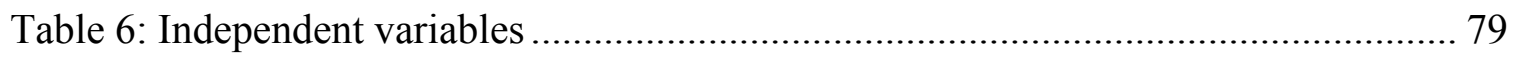

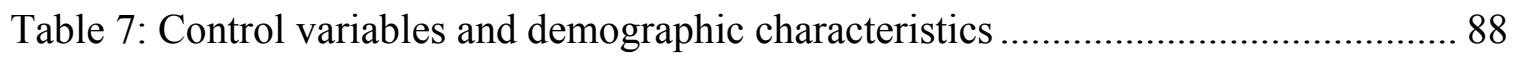

Table 8: Dependent variables - Business plans ........................................................ 93

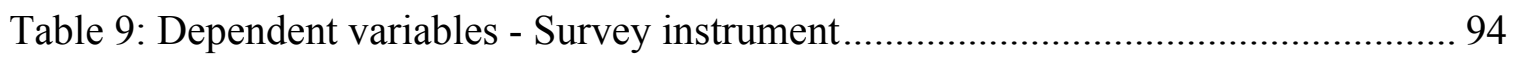

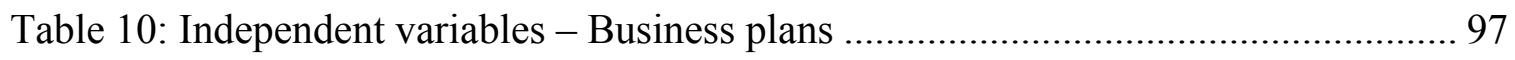

Table 11: Independent variables - Survey instrument.......................................... 100

Table 12: Control variables - Business Plans........................................................... 102

Table 13: Demographic characteristics - Survey instrument ................................... 103

Table 14: Partnership importance to social ventures .............................................. 107

Table 15: Social venture structure and competitive advantage ................................. 108

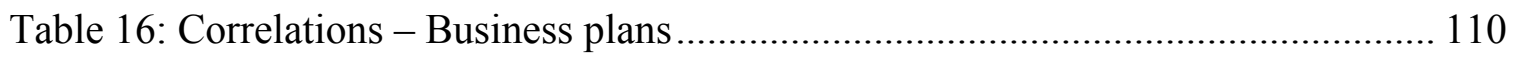

Table 17: Correlations - Survey instrument.......................................................... 112

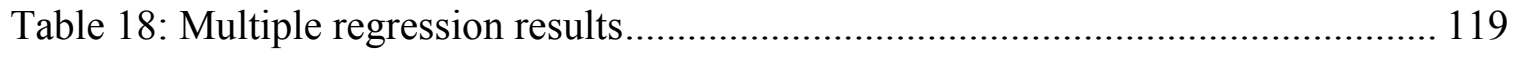

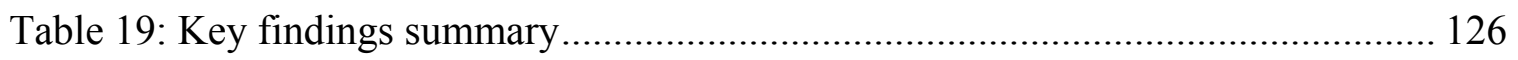




\title{
LIST OF DEFINITIONS AND NOMENCLATURE
}

\author{
Social ventures
}

Entrepreneurship

Social entrepreneurship

Social venture

Nonprofit social ventures

Social purpose forprofit ventures

Hybrid social ventures
The activity or field that focuses on the process of creating value by combining a unique package of resources to address an opportunity or to provide a solution to a problem for an economic purpose.

The activity or field that focuses on the process of creating value by bringing together a unique package of resources to address unmet social needs and to create social value.

The venture or organizational entity that creates value by bringing together a unique package of resources to address unmet social needs and create social value. Social ventures are legally structured as nonprofit organizations, social purpose for-profit ventures, or hybrid ventures. Social ventures are often also referred to as social enterprises or social entrepreneurial ventures.

Nonprofit organizations are one type of social venture. They focus on fulfilling their social mission through entrepreneurial mechanisms and/or by developing products or services that earn revenue and facilitate the achievement of social value by lessening the dependence on external financing sources. They differ from most traditional nonprofits since they are more entrepreneurial in achieving their social mission and seek to provide services or products which generate income. For example, nonprofit microfinance social ventures earn revenue through the interest they charge for their loans.

Social purpose for-profit ventures are one type of social venture. They primary have a social mission, but their goals are also economic as they earn income and are set up as a for-profit entity (Neck, Brush, \& Allen, 2009). The most prominent examples of social purpose ventures are in the health care and education sectors. These include for-profit hospitals or charter schools whose primary mission is to positively benefit society, but who must be profitable in order to stay in business.

Hybrid social ventures blur the lines between for-profit and nonprofit social ventures by combining economic and social missions and goals (Neck et al., 2009; Peredo \& McLean, 2006; Wilson, 2009). These hybrid ventures usually have both nonprofit and for-profit components. For example, the Greyston Bakery is a 
Traditional nonprofits

Earned income (Social venture strategy)

Social innovation (Social venture strategy) for-profit entity which sells baked goods to large corporations. The Greystone Bakery hires and provides training to the formerly homeless and ex-offenders which enable these individuals to learn basic skills and to become integrated back into the community. At the same time the Greystone Bakery donates their profits to their nonprofit arm, The Greyston Foundation, which helps low-income individuals in New York attain self-sufficiency through various social initiatives (http://www.greystonbakery.com/).

Traditional nonprofits include charitable organizations, social welfare organizations, and clubs (Galaskiewicz, Bielefeld, \& Dowell, 2006). Clubs serve a private purpose, while charitable organizations serve a public purpose but have limits on their political activities or lobbying compared to social welfare organizations. These charitable nonprofits mostly rely on donations, but often must pursue profit-making strategies to cover costs (Galaskiewicz et al., 2006). Thus some types of traditional charitable nonprofits can be considered nonprofit social ventures.

Earned income represents financial revenues generated for services, programs, or products provided by a social venture which also enable social venture beneficiaries or clients to enhance their own wealth and improve their standard of living (Nicholls, 2005). These revenues may be directly related to the mission (bakery training the homeless), marginally related (cookies sold by Girl Scouts), or unrelated (parking fees at football games) (Galaskiewez et al., 2006). For example, microfinance social ventures help their clients start or grow their businesses by offering loans or other financial services that increase their wealth and that of their communities. At the same time, the microfinance venture earns revenue from the interest fees they charge clients. This revenue, independent of subsidies and grants, helps offset organizational costs and has become increasingly more common in many social ventures (Froelich, 1999; Salamon, 2002).

Many social ventures innovatively use business expertise and market based strategies to more efficiently reach their goals (Boshee \& McClurg, 2003; Dart, 2004; Meyskens, Robb-Post, Stamp, Carsrud, \& Reynolds, 2010; Mort, Weerawardena, \& Carnegie 2003). Since entrepreneurship is commonly associated with innovation (Kirzner, 1973, 1979; Schumpeter, 1934), it is no surprise that many scholars focus on the innovative aspects of social entrepreneurship (Dees, 1998). In this dissertation social innovation refers to a social ventures use of a new technology, implementation of a product or service to a new market, and the 
use of innovative strategies or business models to implement products or services.

\section{Resource based view}

Competitive advantage

Venture development

Value creation

Launch

Resource gaps
In the context of nascent social ventures, competitive advantage is not related to the ability to achieve greater profit, rather it is based on the ability to achieve more venture development activities, actually launch, and create more value.

Nascent ventures are in the process of development and different activities represent success or a competitive advantage compared to other ventures. This includes opening a bank account, building a website, having a client, attaining a patent, developing a prototype, or implementing a pilot project. Nascent social ventures that are able to achieve more venture development activities have an advantage over other ventures as these activities indicate they are further developed and are more likely to reach their value creation goals.

The primary purpose of a social venture is to benefit society and create social value. Social value operates in many different ways. Whitman (2009) identifies thirty-three different types of social value including empowering communities, promoting education, equality, freedom, health peace, social order and sustainability. Social value benefits society in the form of employment and personal development (Southern, 2001: 265; Nicholls, 2005), environmental betterment (Neck et al., 2009), and improved standard of living. These different types of social value ultimately facilitate the development of communities or regions (Meyskens, Carsrud, \& Cardozo, Forthcoming; Peredo \& Chrisman, 2006). In addition, this social value results in economic benefit for social ventures and their beneficiaries in the form of earned income, wealth creation, and capital accumulation (Whitman, 2009). A social venture that has the potential to achieve more value has a competitive advantage over other type of ventures.

Nascent social venture that are able to launch or start operations have a competitive advantage over other social ventures that have not launched.

Nascent social ventures are generally small and their capacity is constrained by the low level of resources they either own or control (Aldrich, 1999). Thus, nascent social ventures, like their commercial venture counterparts, face many resource gaps. These 
Resource conditions gaps include lack of financial, physical, social, and human capital resources available internal to the venture. Thus, social ventures must couple internal strengths with external resources to address these resource gaps.

RBV suggests that resource conditions leading to a firm's efficiency and effectiveness need to be valuable, rare, inimitable, and imperfectly substitutable (Barney, 1991). Scholars have proposed a number of resource typologies that meet these resource conditions. This study focuses on the role of a heterogeneous combination of financial, physical, social, and human capital resources attained through partnerships. Heterogeneous resource conditions are important for a social venture to attain a competitive advantage.

\section{Partnerships}

Partnerships In a partnership two or more organizations exchange something of value, and the partnership endures beyond a single transaction. The degree of partnership intensity ranges from loose collaboration to more formal administrative consolidation and joint programming to complete integration through mergers or joint ventures (Arsenault, 1998; Kohm, La Piana, \& Gowdy, 2000). In this dissertation the term partnership refers to a mutual exchange or sharing of resources between two or more organizations in order to maximize value creation. Partnerships can be with organizations from the public, private, or social sectors.

Public sector

The public or government sector includes government agencies, schools, universities, and other entities owned at least partially by the government. Each public sector entity is supported by taxation rather than through voluntary market exchange (Schaeffer \& Loveridge, 2002) and exhibits different levels of "publicness" (Bozeman \& Bretschneider, 1994). The public sector acts to meet the needs, general welfare, and interests of its constituents by supporting other sectors and by setting policy and legal parameters (Maase \& Bossink, 2010).

Private sector

The private or corporate sector includes corporations, financial institutions, or businesses whose primary goal is to maximize economic returns. The private sector creates employment opportunities and also provides resources and know-how, but profits are distributed to owners or stakeholders (Maase \& Bossink, 2010). 
Social sector

The social sector operates outside the market or state and broadly describes all aspects of society that extend beyond the public sector and the private sector (Pharr, 2003). The social sector is often also referred to as the nonprofit, civil, or third sector (Drayton, 2002; Teegan, Doh, \& Vachani, 2004) and has expanded where the public and private sectors fail to adequately address social problems. The social sector includes individual beneficiaries, citizens, as well as nonprofit, social, and nongovernmental organizations like religious entities, foundations, community organizations, and social service organizations that represent various social interests (Fox, Interamerican Development Bank, Brakarz, \& Cruz Fano, 2005: 16-17). The primary goal of the social sector is to create social value and positively benefit society.

Partnership Partnership diversity reflects a diverse array of different types of diversity partnerships with organizations from the public, private, and social sectors. 


\section{CHAPTER 1: INTRODUCTION AND OVERVIEW}

The pursuit of entrepreneurial opportunities by social ventures to create societal value has received increasing attention in the management literature. Although some types of social ventures have been studied extensively in the nonprofit and sociology literature, social venture scholarly research in the field of management is still at an early stage of development (Dees \& Anderson, 2006; Dorado, 2006; Mair \& Martí, 2006; Weerwardena \& Mort, 2006). Social ventures operate as nonprofit, for-profit, or hybrid organizations whose primary purpose is to address unmet social needs and create social value (Austin, Stevenson, \& Wei-Skillern, 2006; Certo \& Miller, 2008; Neck, Allen, \& Brush, 2009; Short, Moss \& Lumpkin, 2009, Van de Ven, Sapienza \& Villanueva, 2007; Zahra, Gedajlovic, Neubaum, \& Shulman, 2009) through entrepreneurial processes (Mair \& Noboa, 2006; Meyskens, Robb-Post, Stamp, Carsrud, \& Reynolds, 2010; Perrini \& Vurro, 2006; Shaw, Shaw, \& Wilson, 2002). Social ventures address social challenges and problems, from poverty to health to education to the environment (Emerson, Freundlich, \& Fruchterman, 2007).

Entrepreneurial ventures create value (Bourdieu, 1990; DiMaggio, 1997) by combining a unique package of resources to address an opportunity (Morris, Kuratko, \& Schindehutte 2001) or to provide a solution to a problem (Becker, 1964) for an economic purpose

(Kirzner, 1979; Schumpeter, 1934). Social ventures, like commercial entrepreneurial ventures, create value by bringing together a unique package of resources. However 
social ventures focus on addressing unmet social needs and creating social value. These unmet social needs are not satisfactorily addressed by government or society. For example, microfinance organizations are well known types of social ventures which operate as for-profit, nonprofit, and hybrid legal entities. These organizations offer loans or financial services to micro-entrepreneurs who do not have access to traditional financial institutions and as a result these organizations create social value. At the same time, these microfinance social ventures generate revenue through the interest they charge, and thus generate economic value for themselves and facilitate the creation of wealth for their beneficiaries or clients, the micro-entrepreneur.

As with commercial entrepreneurial ventures in general, there is much we still don't understand about social ventures (Dees, 1998), particularly with regards to how social ventures develop a competitive advantage. In management research, scholars have mostly focused on describing social ventures rather then on predicting outcomes (Short et al., 2009). Few management studies systematically use theory to advance social venture research and most articles are conceptual (Short et al., 2009). In order to increase the legitimacy of social ventures in the management field, more theory driven research questions and quantitative research are necessary (Cummings, 2007). This dissertation addresses these gaps in the social venture literature. 


\section{Research question}

One question that often arises in the literature and by practitioners is how do social ventures develop a competitive advantage? Nevertheless, existing social venture management research has not adequately analyzed this question empirically. Most existing social venture academic research uses case studies or anecdotes, and even the more quantitative scholarly work has been less theory driven than research in other areas. This dissertation assesses one of the means by which social ventures gain a competitive advantage by applying frameworks and theoretical insights from the fields of strategy and entrepreneurship. Applying this theoretical lens provides a unique means to better understand social ventures.

This dissertation systematically assesses and empirically examines the research question: How do partnerships lead to a competitive advantage? Specifically, this dissertation applies resource-based view (RBV) theory from strategy to link partnerships, resource conditions, and strategies with a competitive advantage. Understanding how partnerships or strategic alliances assist in the development of a competitive advantage makes an important contribution to the social venture literature. Given the nature of nascent social ventures, competitive advantage is not assessed in terms of traditional measures of profitability, but rather through social venture development, value creation, and the ability to launch. In order for these early stage ventures to better impact society they need to develop and launch as a venture so that they are able to create more value. Overall, this research increases understanding of social ventures and provides 
quantitative empirical insight into how to improve social ventures development and ability to launch, which ultimately facilitate the creation of social value.

\section{Theoretical lens}

This dissertation systematically applies an RBV theoretical lens to nascent or early stage social ventures to better understand how they gain a competitive advantage. In the context of nascent social ventures, competitive advantage is not primarily related to the ability of a social venture to achieve more profit, but rather their potential to create more social value, which is enhanced by achieving more venture development activities and actually being able to launch. The primary goal of a nascent social venture is to create social value and benefit society. Thus a social venture that has the potential to achieve more social value has a competitive advantage over other social ventures. At the same time, nascent early stage social ventures are in the process of development and different activities represent success or a competitive advantage compared to other ventures. These venture development activities include building a website, opening a bank account, achieving positive cash flow, attaining a patent, developing a prototype, and implementing a pilot project. Nascent social ventures that are able to achieve more venture development activities have an advantage over other early stage ventures as these activities indicate they are further developed and more likely to launch and reach their value creation goals. Thus, nascent social ventures achieve a competitive advantage through value creation, venture development, and actually launching. 
RBV traditionally emphasizes internal sources of competitive advantage gained through heterogeneous resources (Barney, 1991; Wernerfelt, 1984). Ventures leverage existing resources to obtain additional resources (Greene, Brush, \& Hart., 1999) and create new capabilities (Stopford \& Baden-Fuller, 1994). In the RBV framework, entrepreneurial strategies help fill resource gaps through internal development, market transactions, acquisitions, and partnerships (Teng, 2007). Social ventures are likely to face resource gaps, yet they pursue opportunities and growth regardless (Dees, 1998) by using entrepreneurial processes to mobilize resources to address unmet social needs and create social value (Austin et al., 2006; Mair \& Marti, 2006; Neck et al., 2009; Zahra et al., 2009). Thus, RBV is a relevant approach toward understanding social ventures.

Although researchers discuss the general importance of resources in commercial ventures (Alvarez \& Barney, 2002; Brush, Greene, \& Hart, 2001; Greene \& Brown, 1997), social ventures (Leadbeater, 1997; Mair \& Marti, 2006; Peredo \& McLean, 2006; Waddock \& Post, 1991), and nonprofit organizations (Galaskiewicz, Bielefeld, \& Dowell, 2006; Stone, Bigelow, \& Crittenden, 1999), much less has been done to systematically apply an RBV theoretical lens to social ventures. In the last few years, Meyskens, Robb-Post, Stamp, Carsrud, and Reynolds (2010) apply the RBV to understand the operational processes of social ventures. Desa (2008) uses the RBV and resource dependency theories to assess how social technology ventures mobilize resources in resource constrained environments through bricolage (bootstrapping) and resource seeking strategies. Seelos and Mair (2007) ground their argument in RBV to better understand how companies can use partnerships and existing capabilities to successfully serve lower 
income customers at the bottom of the pyramid. Collectively, these studies provide greater insight into the role of resources in social ventures. However, they fall short in offering a RBV framework that systematically answers a critical RBV question: How do social ventures develop a competitive advantage? Thus, this paper fills a theoretical gap by examining social ventures systematically in light of a prominent strategy theory.

Partnerships or strategic alliances serve as one means by which social ventures develop adequate resource conditions and strategies that lead to a competitive advantage (Teng, 2007). Partnerships have been studied extensively in strategic management (Das \& Teng, 2000; Gulati, 1998; Lavie, 2006), international business studies (Blodgett, 1991; Lyles \& Salk, 1997), and in the nonprofit literature (Guo \& Acar, 2005; Kourula \& Laasonen, 2010). Partnerships serve as a means to attain a competitive advantage (Dubini \& Aldrich, 1991; Googins \& Rochlin, 2000; Rondinelli \& London, 2003). Existing studies focus on how entrepreneurial ventures (Jack, 2010) and nonprofit organizations (Galaskiewicz et al., 2006; Guo \& Acar, 2005; Kourula \& Laasonen, 2010) utilize partnerships or networks of partnerships to reach their goals. Although these studies cover some aspects of the linkage between partnerships, resource conditions, strategies, and competitive advantage, they do not offer a theoretical framework that analyzes social ventures and their partnerships systematically. The RBV enables such a linkage, and in the process contributes to the development of social venture research in management providing insight to assist practitioners in better understanding means to efficiently and effectively create value. 


\section{Conceptual model}

This dissertation uses an RBV theoretical lens to provide insight into how partnerships facilitate the development of social venture strategies and adequate resource conditions that lead to a competitive advantage. According to the conceptual model in Figure 1, nascent social ventures engage in partnerships to access needed resources. These partnerships are with public sector, private sector, and social sector partners. Public sector partners include governmental entities, universities, and schools. Private sector partners include corporations and financial institutions. Social sector partners include other social ventures, religious entities, individuals, and the community. Partnership diversity reflects when a social venture has a variety of partnerships with entities from different sectors and represents the embedded network in which social ventures operate. Partnership diversity helps lead to desirable resource conditions as distinct sectors contribute different types of resources.

The resource conditions are achieved through the mobilization of human capital, financial capital, physical capital and social capital through partnerships. In the context of nascent social ventures, human capital includes volunteers or knowledge. Financial capital includes monetary support. Physical capital includes office space, equipment, and inputs. Social capital includes access to networks, resources, or beneficiaries. Together, these different types of capital lead to the development of heterogeneous resource conditions where a nascent social venture has access to distinct resources that facilitate the achievement of a competitive advantage. Thus, resource conditions mediate the relationship between partnerships and a competitive advantage. 


\section{Figure 1: Conceptual model}

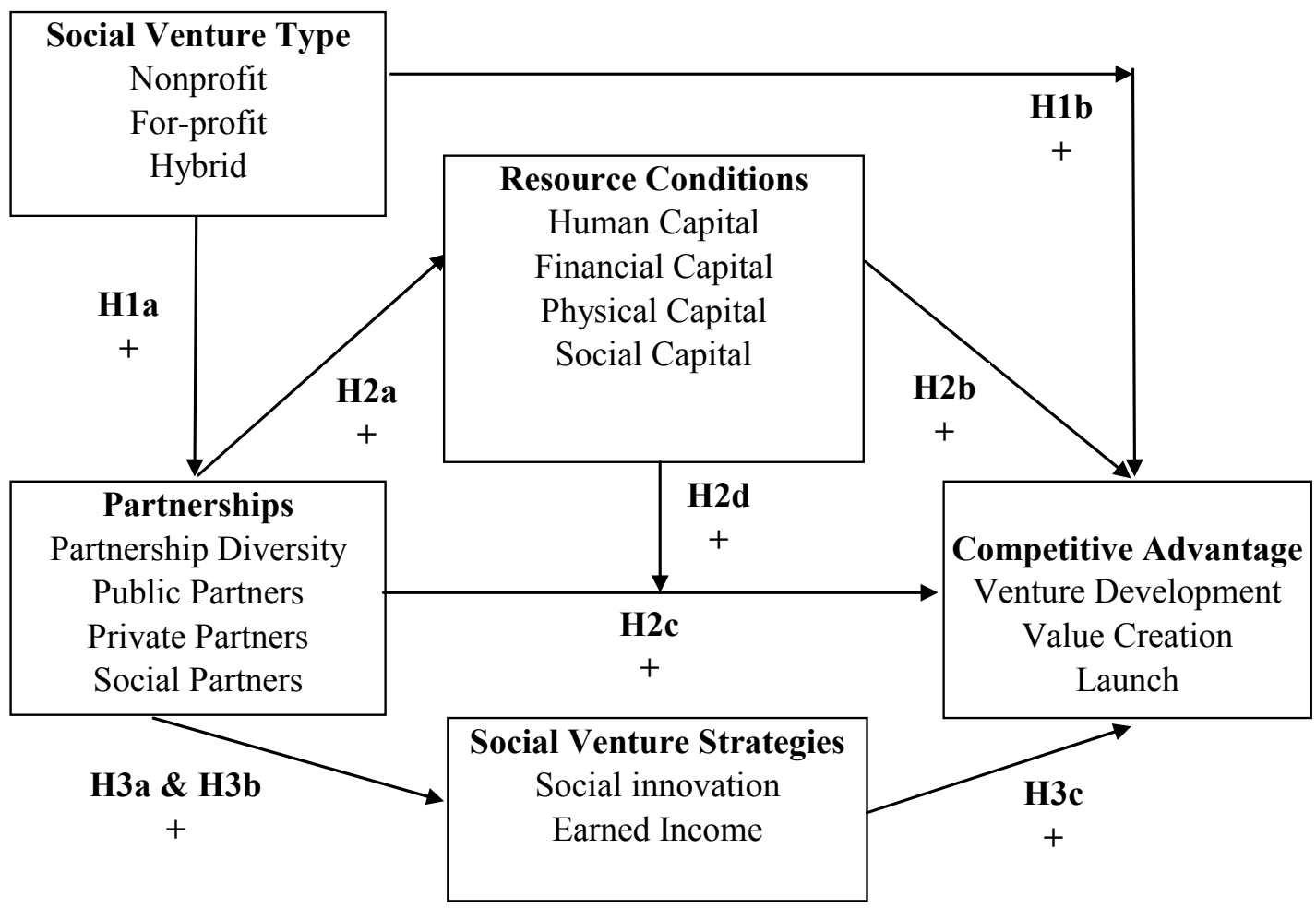

Social ventures also seek to develop a diverse array of partnerships that facilitate social innovation and earned income strategies. More innovative ventures are able to develop more means to be competitive. At the same time, social ventures that earn more income have greater access to resources. Partners assist in the development and implementation of these strategies and these strategies are important in helping early stage social ventures achieve venture development activities, the launch of the venture, and the creation of value. Nascent social ventures that achieve more venture development and actually launch can create more value. Thus they have a competitive advantage over their peers as they are more likely to achieve their primary purpose of creating social value. These relationships identified in the conceptual model will be explored through the hypotheses. 


\section{Method}

This dissertation systematically assesses how social venture partnerships lead to a competitive advantage in the context of nascent social ventures that participated in United States based social venture business plan competitions. These business plan competitions are sponsored by universities and nonprofit organizations and take place between the years 2004 to 2009 . The nascent social ventures in the sample are legally structured as nonprofit, for-profit, and hybrid organizations and represent many different areas of impact. Given the different types of social ventures and relative newness of the phenomenon, analyzing ventures that participated in these competitions provides a convenience sample of social ventures at early stages of development. Approximately 45 social venture business plan competitions are held every year in the United States. This research uses social venture business plans collected from 15 different sponsoring institutions.

This study employs a two phase design to answer the research question. After initial exploratory analysis and a pilot study, a codebook is developed. Two raters independently code variables in business plans in order to evaluate the hypotheses. A survey of the social ventures is conducted to gather additional variables. The final sample includes 179 social ventures from the content analysis and 72 social ventures from the exploratory follow-up survey. After cleaning the data, the hypotheses are analyzed using several different statistical techniques. Finally, the results are presented and discussed. 


\section{Contributions and findings}

This dissertation provides insight into the role of partnerships in attaining appropriate resource conditions and developing strategies to create a competitive advantage through venture development, value creation, and launching. This research is important as social ventures not only provide direct social benefits, but also contribute to job growth and labor productivity (Bosma, Acs, Autio, Coduras, \& Levie, 2008). By examining the RBV in the context of nascent social ventures this dissertation makes several contributions to social venture research and also has important practical implications.

1. $\underline{\mathbf{R B V}}$. This study is one of the earliest to systematically apply and empirically assess the RBV in the context of social ventures. Most existing management scholarly research on social ventures bases findings on case studies or anecdotal evidence. This has led to many studies that describe social ventures and remark on the importance of enabling partnerships.

2. Partnerships. This study analyzes the importance of partnerships for social ventures as a means to develop heterogeneous resource conditions and a competitive advantage. Existing research in the nonprofit context focuses on single sector or cross-sector partnerships, but not the broad range of partnerships with different types of organizational entities which actually make up the network of partnerships with which social ventures interact to reach their goals. This dissertation finds a significant relationship between partnership diversity and the achievement of a competitive advantage. Founder previous experience, client location, and business 
3. Strategies. This research examines the relationship between partnerships, earned income and social innovation strategies, and the development of a competitive advantage. As social ventures develop more distinct types of partnerships, the number of different products or services (earned income streams) increases. However when earned income is the primary revenue stream, partnership diversity decreases. At the same time, earned income is positively related to venture development and launching. Partnership diversity is also positively related to social innovation which is associated with venture development and the launching of social ventures.

4. Firm creation process. This study increases understanding of the firm creation process in the context of social ventures and suggests that the firm creation process of nascent social ventures is similar to that of traditional commercial ventures. The applicability of the RBV to this context and the importance of partnership diversity to the development of heterogeneous resource conditions, strategies, and a competitive advantage represent similar operational processes as that which would be found in traditional commercial ventures. 
5. Practitioners. This research provides insight to social venture practitioners by highlighting different means they can facilitate the creation of value. Most social ventures engage in partnerships with other entities. The results suggest that a broad range of partnerships with different types of entities are important to the creation of value and the development of a social venture. At the same time, these partnerships can assist in the development of strategies that emphasize earned income or that are socially innovative. Both social venture practitioners and sponsors of social venture business plan competitions should emphasize the importance of partnership diversity, social capital, founder previous experience, and business plan completeness to success and facilitate means to develop these resources or characteristics to facilitate the launch of the social venture.

6. Dataset. This study builds a dataset and develops measures which can be used to analyze many interesting research questions related to social ventures in the future. For example, the exploratory data on partnership importance and green-tech ventures has been analyzed using the framework presented in the dissertation (Meyskens \& Carsrud, $2009 \&$ 2010). At the same time future research can more thoroughly examine the role of specific types of partnerships, resources, and types of competitive advantage through interviews, qualitative research, and surveys with larger sample sizes. Conducting a longitudinal cross-cultural comparative study on social ventures would also provide greater insight into nascent social ventures over time and how they operate in different environmental contexts and institutional settings. In 
Research on social ventures is evolving in a similar manner as other scholarly fields, first focusing on the definition through mostly qualitative and non-empirical research, and now expanding to develop more theoretically driven quantitative empirical research. This dissertation plays an important role in further understanding this field.

\section{Dissertation format}

In order to develop these themes, the paper is divided into six subsequent chapters. The literature review discusses social ventures, the resource based view, and the role of partnerships in attaining resources and developing strategies that lead to a competitive advantage. The third chapter develops and presents the hypotheses as summarized in the conceptual model. The fourth chapter discusses the methodology, details the sample of nascent social ventures, and describes the content analysis and coding procedure used to develop and examine the variables in these relationships. The fifth chapter analyzes and discusses the results. The final chapter details conclusions, contributions, limitations, and opportunities for future research. 


\section{CHAPTER 2: LITERATURE REVIEW}

This section reviews the literature relevant for this dissertation by discussing the characteristics of social ventures, the resource based view as the theoretical link underlying this research, partnerships as a vehicle for facilitating heterogeneous resource conditions, and earned income and social innovation strategies that lead to a competitive advantage.

\section{Social ventures}

Social ventures address social needs through entrepreneurial processes (Mair \& Noboa, 2006; Meyskens et al., 2010; Perrini \& Vurro, 2006; Shaw et al., 2002) to achieve their primary purpose of creating social value (Austin et al., 2006; Short et al., 2009, Zahra et al., 2009). Social ventures achieve their goals as for-profit social purpose ventures, nonprofit entities, and hybrid organizations (Neck et al., 2009; Townsend \& Hart, 2008). A prominent example of a social venture includes the company Newman's Own. The for-profit condiment company distributes their profits to social causes through their

nonprofit arm and thus operates as a social venture (http://www.newmansownfoundation.org/). Other well-known examples of social ventures are microfinance organizations which provide loans and financial services to individuals who do not have access to mainstream financial services. Microfinance social ventures are legally structured as for-profit, nonprofit, or hybrid entities (http://www.microfinancegateway.org/p/site/m/template.rc/1.26.12263/\#6). 
Social ventures have been analyzed extensively in the nonprofit literature, but only recently have scholars wholeheartedly integrated social ventures into mainstream academic management research and begun to apply management frameworks and theories to these ventures. Social venture management research is primarily conducted under the realm of entrepreneurship, but also falls under the fields of international business and strategy when considering corporate relationships with social ventures through corporate social responsibility initiatives.

The increase in social venture research by management scholars is growing as more business students seek to make a difference in the world (Stevenson, 2008) and as business schools react to develop more courses (Brock \& Ashoka's Global Academy for Social Entrepreneurship, 2006; Krueger, Welsh, \& Brock, 2007) and university centers dedicated to social ventures (Hoogendoorn, Pennings, \& Thurik, 2009). Short, Moss and Lumpkin (2009) identify 152 articles focused on social entrepreneurship and social ventures in academic journals over the last twenty years from a variety of disciplines, while Hill, Kotharthi, and Shea (2010) find 212 scholarly social venture articles published in 128 journals between 1968 and 2007. At the same time, a plethora of Special Issues in management academic journals such as the Journal of World Business (2006), Journal of Business Venturing (2010), Entrepreneurship Theory \& Practice, (2010), and Entrepreneurship \& Regional Development (2010) have recently focused on social ventures. 
Much of this early management scholarly effort is dedicated to defining social ventures (Dees, 1998; Mair \& Martí, 2006; Peredo \& McLean, 2006; Perrini \& Vurro, 2006; Weerawardena \& Mort, 2006; Zahra et al., 2009), describing their relationship with commercial ventures (Austin et al., 2006; Chell, 2007; Dorado, 2006; Mair \& Martí, 2006; Meyskens et al., 2010) and nonprofit organizations (Boschee \& McClurg, 2003; Dees \& Anderson, $2003 \&$ 2006), and analyzing their characteristics. In his seminal article, Dees (1998) details important characteristics of social ventures such as social value creation, innovativeness, risk-taking, resourcefulness, and accountability. According to Dees (1998), social ventures are not just concerned with wealth creation, since their primary mission is to create and sustain social value. In order to pursue the mission and to sustain social value, social ventures take risks, pursue opportunities, and constantly innovate, adapt, and learn. Social ventures are not limited by the resources at hand. However, social ventures are highly concerned with being accountable to the constituents they serve and the outcomes they create.

Many other researchers have built off Dees (1998) and detailed the characteristics of social ventures (Weerawardena \& Mort, 2006; Zahra et al., 2009) with mixed motives and dimensions. A broad range of themes and strategies have been explored to describe social ventures including entrepreneurial characteristics, resource conditions, value creation, social innovation, earned income, and legal structure. This research is summarized in Table 1. 
Table 1: Social venture characteristics and strategies

\begin{tabular}{|c|c|}
\hline \multicolumn{2}{|r|}{ Entrepreneurial characteristics } \\
\hline Brinkerhoff (2001) & $\begin{array}{l}\text { The identification of new ways to serve constituencies and add value to } \\
\text { existing services. }\end{array}$ \\
\hline $\begin{array}{l}\text { Hibbert, Hogg, \& } \\
\text { Quinn (2001) }\end{array}$ & $\begin{array}{l}\text { The use of entrepreneurial behavior for social ends rather than for-profit } \\
\text { objectives; or a venture that generates profits that benefit a specific } \\
\text { disadvantaged group. }\end{array}$ \\
\hline $\begin{array}{l}\text { Shaw, Shaw, \& Wilson } \\
(2002)\end{array}$ & $\begin{array}{l}\text { Bringing to social problems the same enterprise and imagination that } \\
\text { business ventures bring to wealth creation. }\end{array}$ \\
\hline Kerlin (2006) & $\begin{array}{l}\text { The use of nongovernmental, market-based approaches to address social } \\
\text { issues. }\end{array}$ \\
\hline $\begin{array}{l}\text { Emerson, Freundlich, } \\
\text { \& Fruchterman (2007) }\end{array}$ & $\begin{array}{l}\text { The application of business models and acumen to address social issues, } \\
\text { whether through nonprofit or for-profit corporate structures. }\end{array}$ \\
\hline $\begin{array}{l}\text { Meyskens, Robb-Post, } \\
\text { Stamp, Carsrud, \& } \\
\text { Reynolds (2010) }\end{array}$ & $\begin{array}{l}\text { The relationship between partnerships, financial capital, innovativeness, } \\
\text { legal structure, and knowledge transferability in social ventures is similar } \\
\text { to that seen in commercial ventures. }\end{array}$ \\
\hline \multicolumn{2}{|r|}{ Resource conditions } \\
\hline $\begin{array}{l}\text { Waddock \& Post } \\
\text { (1991) }\end{array}$ & $\begin{array}{l}\text { The creation or elaboration of a public organization so as to alter the } \\
\text { existing pattern of allocation of scarce public resources }\end{array}$ \\
\hline Leadbeater (1997) & $\begin{array}{l}\text { Social ventures identify and mobilize underutilized resources and use } \\
\text { entrepreneurial behavior to achieve social objectives. }\end{array}$ \\
\hline Chell (2007: 14) & $\begin{array}{l}\text { Both social and economic entrepreneurs garner alienable resources } \\
\text { (through networking and other processes) and use their personal or } \\
\text { human capital in order to achieve their espoused mission of wealth and } \\
\text { social value creation. }\end{array}$ \\
\hline $\begin{array}{l}\text { Zahra, Gedajlovic, } \\
\text { Neubaum,, \& Shulman } \\
\text { (2009) }\end{array}$ & $\begin{array}{l}\text { Social bricoleurs are especially clever in assembling and deploying } \\
\text { resources in pursuit of a social cause by benefitting from local knowledge } \\
\text { and opportunities. Social constructionists acquire their resources through } \\
\text { collaborative ventures without diluting their missions. Social engineers } \\
\text { bring revolutionary change to social problems that require them to } \\
\text { marshal great resources. }\end{array}$ \\
\hline \multicolumn{2}{|r|}{ Value creation } \\
\hline $\begin{array}{l}\text { Emerson \& Bonini } \\
(2003: 14)\end{array}$ & $\begin{array}{l}\text { Blended value posits that value is generated from the combined interplay } \\
\text { between the component parts of economic, social and environmental } \\
\text { performance. All firms (whether nonprofit or for-profit) create blended } \\
\text { value to varying degrees. This can be tracked through the use of a Triple } \\
\text { Bottom-Line framework. }\end{array}$ \\
\hline $\begin{array}{l}\text { Clark, Rosenzweig, } \\
\text { Long, \& Olsen (2004) }\end{array}$ & $\begin{array}{l}\text { Double bottom line entrepreneurial ventures strive to achieve measurable } \\
\text { social and financial outcomes. }\end{array}$ \\
\hline Choi \& Gray (2008) & $\begin{array}{l}\text { Socially responsible, values-led, ethical, or sustainable ventures } \\
\text { simultaneously achieve economic, environmental, and social goals. }\end{array}$ \\
\hline $\begin{array}{l}\text { Meyskens, Carsrud, \& } \\
\text { Cardozo (Forthcoming) }\end{array}$ & Social ventures attain economic and social value through partnerships. \\
\hline \multicolumn{2}{|r|}{$\begin{array}{r}\text { Social innovation } \\
\end{array}$} \\
\hline Borins (2000) & Public sector organizations that have innovative leaders. \\
\hline $\begin{array}{l}\text { Tan, Williams, \& Tan } \\
(2005)\end{array}$ & $\begin{array}{l}\text { The making of profits through innovation in the face of risk, where all or } \\
\text { part of the benefits accrue to the same segment of society. }\end{array}$ \\
\hline $\begin{array}{l}\text { Mair \& Marti (2006: } \\
\text { 37) }\end{array}$ & $\begin{array}{l}\text { The innovative use and combination of resources to pursue opportunities } \\
\text { to catalyze social change and/or address social needs. }\end{array}$ \\
\hline Brooks (2008) & The use of innovative behavior for social objectives. \\
\hline
\end{tabular}




\begin{tabular}{|c|c|}
\hline \multicolumn{2}{|r|}{ Earned income } \\
\hline Campbell (1997) & $\begin{array}{l}\text { Providing communities with needed products or services and generate } \\
\text { profit to support activities that cannot generate revenue }\end{array}$ \\
\hline $\begin{array}{l}\text { Di Dominico, Tracey, } \\
\& \text { Haugh (2009: 894) }\end{array}$ & $\begin{array}{l}\text { "A nonprofit venture which aims to achieve a given social purpose } \\
\text { through strategies which generate income from commercial activity. } \\
\text { However they are different than corporations in that they hold wealth in } \\
\text { trust for community benefit, they democratically involve stakeholders in } \\
\text { organizational governance and they seek to be accountable to the } \\
\text { constituencies they serve (Pearce 2003)... They are different from } \\
\text { traditional nonprofit organizations in their pursuit of commercial activity } \\
\text { rather than reliance on grants, donations or membership fees." }\end{array}$ \\
\hline $\begin{array}{l}\text { Social Enterprise } \\
\text { Alliance }\end{array}$ & $\begin{array}{l}\text { Any earned income business or strategy undertaken by a nonprofit to } \\
\text { generate revenue in support of its charitable mission }\end{array}$ \\
\hline \multicolumn{2}{|r|}{ Legal structure } \\
\hline $\begin{array}{l}\text { Austin, Stevenson, \& } \\
\text { Wei-Skillern (2006) }\end{array}$ & $\begin{array}{l}\text { An innovative, social value-creating activity that can occur within or } \\
\text { across the nonprofit, business, or government sectors which combines } \\
\text { commercial enterprises and social impact. }\end{array}$ \\
\hline $\begin{array}{lll}\text { Townsend } & \& & \text { Hart } \\
(2008) & & \end{array}$ & $\begin{array}{l}\text { Ventures that have different organizational or legal structures help } \\
\text { address economic and social needs. Social venture founders' perceptions } \\
\text { of an ambiguous institutional environment lead to the variance in choice } \\
\text { of organizational form for social ventures. }\end{array}$ \\
\hline $\begin{array}{l}\text { Neck, Brush \& Allen } \\
(2009)\end{array}$ & $\begin{array}{l}\text { The landscape of social ventures includes social purpose ventures, } \\
\text { enterprising nonprofits, and hybrid ventures. }\end{array}$ \\
\hline $\begin{array}{l}\text { Hoogendoorn, } \\
\text { Pennings, \& Thurik } \\
(2009)\end{array}$ & $\begin{array}{l}\text { According to the European school, social ventures are legally } \\
\text { incorporated as a co-operative or association. Yet legal structures vary } \\
\text { across countries according to different legal systems. }\end{array}$ \\
\hline \multicolumn{2}{|r|}{ Comprehensive } \\
\hline Dees (1998) & $\begin{array}{l}\text { Social ventures serve as change agents in the social sector, by: 1) } \\
\text { Adopting a mission to create and sustain social value, 2) Recognizing and } \\
\text { relentlessly pursuing opportunities to serve that mission, 3) Engaging in a } \\
\text { process of continuous innovation, adaption and learning, 4) Acting boldly } \\
\text { without being limited by the resources currently in hand, and 5) } \\
\text { Exhibiting heightened accountability to the constituencies served and } \\
\text { outcomes created. }\end{array}$ \\
\hline $\begin{array}{l}\text { Weerawardena \& Mort } \\
(2006: 76)\end{array}$ & $\begin{array}{l}\text { A multidimensional construct involving the expression of entrepreneurial } \\
\text { virtuous behavior to achieve the social mission, a coherent unity of } \\
\text { purpose and action in the face of moral complexity, the ability to } \\
\text { recognize social-value creating opportunities, and key decision-making } \\
\text { characteristics of innovativeness, proactiveness, and risk-taking. }\end{array}$ \\
\hline $\begin{array}{l}\text { Peredo \& McLean } \\
\text { (2006: 56) }\end{array}$ & $\begin{array}{l}\text { Social entrepreneurship is exercised where some person or persons (1) } \\
\text { aim either exclusively or in some prominent way to create social value of } \\
\text { some kind, and pursue that goal through some combination of (2) } \\
\text { recognizing and exploiting opportunities to create this value, (3) } \\
\text { employing innovation, (4) tolerating risk, and (5) declining to accept } \\
\text { limitations in available resources. }\end{array}$ \\
\hline $\begin{array}{l}\text { Zahra Gedajlovic, } \\
\text { Neubaum, \& Shulman } \\
(2009: 219)\end{array}$ & $\begin{array}{l}\text { Social entrepreneurship encompasses the activities, and processes } \\
\text { undertaken to discover, define, and exploit opportunities in order to } \\
\text { enhance social wealth by creating new ventures or managing existing } \\
\text { organizations in an innovative manner.' Social wealth is defined broadly } \\
\text { to include economic, societal, health, and environmental aspects of } \\
\text { human welfare. }\end{array}$ \\
\hline
\end{tabular}


Entrepreneurial characteristics. Management academic research suggests that the inputs, outputs, and resource-based operational processes of social and commercial ventures are similar (Brooks, 2008; Mair \& Noboa, 2006; Meyskens et al., 2010). The primary inputs for both social and commercial ventures include the opportunity, resources, individuals, and context (Austin, et al., 2006; Morris, Lewis, \& Sexton, 1994).

Social ventures bring to social problems the same enterprise, business models, acumen, and imagination that commercial entrepreneurs bring to wealth creation (Emerson et al., 2007; Shaw et al., 2002). Many social ventures use business expertise and market based strategies to more efficiently reach their goals (Boshee \& McClurg, 2003; Dart, 2004; Meyskens et al., 2010; Mort, Weerawardena \& Carnegie, 2003; Hoogendoorn et al., 2009). Cool and Vermeulen (2008) compare the similarities and differences in the cognitive approach of commercial and social venture founders and find no significant difference. However they do find that social venture founders engage in apparently less innovative and risk taking approaches in activating their business compared with their commercial counterparts. At the same time, the pursuit of social venture opportunities is motivated by distinct intentions (Mair \& Noboa, 2006) and faces different barriers to entry (Robinson, 2006) than that faced by commercial ventures. For example, in social ventures, the identification of an unmet social need, specifically at a local level, is the basis of opportunity identification (Shaw \& Carter, 2007).

The value creating resource-based operational processes, information flows, and operational behaviors involved in creating social value in social ventures are also similar 
to those used in commercial ventures to develop outputs and outcomes. Meyskens, Robb-Post, Stamp, Carsrud, and Reynolds (2010) find that the relationship between partnerships, financial capital, innovativeness, legal structure, and knowledge transferability in social ventures is similar to that seen in commercial ventures. At the same time, the outputs of both social and commercial ventures include products, services, assets, failure, losses, profits, benefits, and value (Morris et al., 1994). Nevertheless, the primary focus of social ventures is to use entrepreneurial activities to address social needs and create social value (Austin et al., 2006; Certo \& Miller, 2008; Hibbert, Hogg, \& Quinn, 2001; Short et al., 2009; Van de Ven et al., 2007). Social ventures, like commercial entrepreneurial ventures, create value by bringing together a unique package of resources. However, social ventures focus on addressing unmet social needs and creating social value.

Resource conditions. Developing adequate resource conditions is important to facilitate the achievement of social venture goals. Leadbeater (1997) analyzes how social ventures identify and mobilize underutilized resources and use entrepreneurial behavior to achieve social objectives. Waddock and Post (1991) find that social ventures alter the existing pattern of allocation of scarce public resources to achieve their goals. Chell (2007) finds that social ventures garner resources through networking and other processes and use founder personal or human capital in order to achieve social and wealth value creation. Zahra, Gedajlovic, Neubaum, and Shulman (2009) find that all types of social ventures led by social bricoleurs, constructionists, and engineers must develop adequate resource conditions to research their goals. In essence, the research suggests that developing 
adequate resource conditions is important for social ventures to be successful and to attain a competitive advantage.

Value creation. Social ventures produce varying degrees of social, environmental, and economic value according to their strategic objectives. Although social value is the primary goal of a social venture, environmental and economic value creation also benefits society. Social value benefits society in the form of employment and personal development (Southern, 2001: 265; Nicholls, 2005), and improved standard of living. Whitman (2009) identifies thirty-three different types of social value including empowering communities, promoting education, environment, equality, freedom, health, peace, social order, and sustainability. Thus, the social value generated by social ventures facilitates the growth and development of communities or regions (Meyskens et al., Forthcoming; Peredo \& Chrisman, 2006). An important type of social value that is often generated is environmental betterment (Neck et al., 2009). Environmental value positively impacts the environment through recycling or decreasing energy consumption or reducing greenhouse gas emissions or through using environmentally friendly production methods.

At the same time social ventures create economic value at both the individual and firm level of analysis for themselves, their beneficiaries, and their partners (Meyskens et al., Forthcoming). This comes in the form of earned income, wealth creation, and capital accumulation (Whitman, 2009). Zahra, Gedajlovic, Neubaum, and Shulman (2009: 219) describe social wealth as the combination of economic, societal, health, and 
environmental aspects of human welfare. Thus, social ventures seek to generate blended value (Emerson \& Bonini, 2003; Emerson et al., 2007) by developing a double or triple bottom line resulting in social, economic, or environmental benefits (Choi \& Gray, 2008; Clark, Rosenzweig, Long, \& Olsen, 2004).

Social innovation. Two leading social venture schools of thought in the United States focus on the social innovation and earned income strategies that social ventures use to reach their goals (Dees \& Anderson, 2006; Hoogendoorn et al., 2009). Leading the innovation school is Bill Drayton and his social venture Ashoka that identifies leaders to scale novel solutions to address social problems through their social ventures (Dees \& Anderson, 2006; Drayton, 2002). According to Drayton (2002), a social entrepreneur "is nearly the same thing as a business entrepreneur. The social entrepreneur has a similar personality type, but operates in a different arena. Social entrepreneurs focus their entrepreneurial talent on solving social problems--why children are not learning, why technology is not accessed equally, why pollution is increasing, etc. The social entrepreneur recognizes when a part of society is stuck and provides new ways to get it unstuck. He or she attempts to solve the problem by changing the system, spreading the solution and persuading entire societies to take new leaps." For example, Grameen Bank founder Muhammad Yunus developed an innovative plan to bring microcredit to the rural poor in Bangladesh, worked tirelessly for decades to refine the idea, and then replicated it worldwide. 
Since entrepreneurship is commonly associated with innovation (Kirzner 1979; Schumpeter, 1934), it is no surprise that many scholars focus on the innovative aspects of social ventures (Dees, 1998). Nicholls (2006: 5) identifies social ventures as an "umbrella term for a considerable range of innovative and dynamic international praxis and discourse [for ventures operating] in the social and environmental sector." Tan, Williams, and Tan (2005) discuss how social ventures profit through innovation and avoid risks. King and Roberts (1987) define social ventures in terms of their innovation and leadership characteristics. Borins (2000) identifies social venture leaders that innovate in public sector organizations. Weerawardena and Mort (2006) suggest that social ventures are forced to be innovative in all their social value creating activities due to increasing competiveness. Alvord, Brown, and Letts (2004) categorize three types of innovations: (1) increasing the capacities of local actors in solving their own problems, (2) disseminating a package of innovations to serve a widely distributed need, and (3) building a movement to challenge the structural causes of social problems. As can be seen, social innovation facilitates social venture development and achievement of value creation goals.

In this dissertation social innovation refers to the use of technology, the implementation of a new product or service in the market, and the use of innovative strategies or business models to implement products or services. For example, one social venture in the sample proposes to introduce and sell bicycle driven carts to haul goods in Haiti. These carts seek to replace the carts that sometimes weigh up to 500 pounds that are pulled solely by humans. Thus the new product will be new to the market, will introduce a new 
technology innovation (as stated in the business plan), and will integrate the bicycles into the market through a new strategy (microlending program). Thus this social venture is employing all three types of social innovation. Another social venture might just adopt one of these components.

Earned income. The other leading social venture school of thought in the United States focuses on developing earned income for nonprofit social ventures (Dees \& Anderson, 2006; Hoogendoorn et al., 2009). This group led by Surdna Foundation's Edward Skloot (Light, 2006) is represented in the United States by the Social Enterprise Alliance, an industry association. In this dissertation, earned income represents financial revenues generated for services, programs, or products provided by a social venture which also might enable social venture beneficiaries or clients to enhance their own wealth and improve their standard of living (Nicholls, 2005). These revenues may be directly related to the mission (bakery training the homeless), marginally related (cookies sold by Girl Scouts), or unrelated (parking fees at university football games) (Galaskiewez et al., 2006). For example, microfinance ventures help their clients start or grow their businesses by offering loans or other financial services that increase their wealth and that of their communities. At the same time, the microfinance venture earns revenue from the interest fees they charge clients, thereby becoming less dependent on grants and other sources of income.

In addition, some social ventures have a hybrid structure whereby a for-profit social venture provides products or services to support social initiatives, often through a 
nonprofit arm or subsidiary that cannot generate revenue (Campbell, 1997). For example, the for-profit social venture Newman's Own sells condiments directing all the profits to support the philanthropic initiatives of their nonprofit foundation. This revenue, independent of subsidies and grants, helps offset organizational costs and has become increasingly more common in a large variety of nonprofits (Froelich, 1999; Salamon, 2002).

Social ventures use social innovation and earned income strategies to facilitate value creation, venture development, launching, and the achievement of a competitive advantage.

Legal structure. Social ventures are not bound by organizational form or legal structure, but by their social purpose (Townsend \& Hart, 2008). Existing academic literature classifies social ventures into three primary types: social purpose for-profit ventures (Dees \& Anderson, 2003), nonprofit organizations (Boshee, 1995; Dees \& Anderson, 2003), and hybrid ventures (Dees \& Anderson, 2003 \& 2006; Kistruck, 2008; Townsend \& Hart, 2008; Wilson, 2009). Each type produces varying degrees of social value according to the strategic objectives. Social purpose for-profit ventures primary mission is social, but their venture goals are economic as they must generate their own revenue through products or services (Neck et al., 2009). The most prominent examples of social purpose ventures are in the health care and education sectors. These include for-profit hospitals or charter schools whose primary mission is to positively benefit society. Nonprofit ventures focus on fulfilling their social mission through entrepreneurial 
mechanisms or by developing products or services that earn revenue and facilitate the achievement of social value by lessening the dependence on external financing sources. These nonprofit social ventures are more results driven than traditional nonprofits (Dees \& Anderson, 2003, 2006) and are more likely to use business-like behavior in service delivery, management, and rhetoric to more efficiently serve a population or region (Dart 2004). For example, the Girl Scouts raise money to finance their operations and facilitate their social goals by selling cookies (http://www.girlscouts.org)). The Salvation Army sells used clothing to support initiatives that focus on the homeless, youth, elderly, and the needy (http://www.salvationarmyusa.org).

Hybrid social ventures blur the lines between for-profit and nonprofit social ventures by combining economic and social missions and goals (Neck et al., 2009; Peredo \& McLean, 2006). These hybrid ventures often include both nonprofit and for-profit components. For example, Newman's Own is a for-profit company that sells salad dressings and other condiments. However, they donate all their profits to their nonprofit arm which then contributes to different initiatives that help society (http://www.newmansown.com/). Another interesting example is the Greyston Bakery, a for-profit entity which makes baked goods for large corporations and also has developed a Do Goodie Brownie brand. The Greyston Bakery hires the former homeless and exoffenders and provides training which enables these individuals to learn basic skills and become integrated back into the community. At the same time the Greystone Bakery donates their profits to their nonprofit arm, the Greyston Foundation, which helps low- 
income individuals in New York become self-sufficient through various initiatives (http://www.greystonbakery.com/).

\section{Resource based view}

The resource based view (RBV) has become one of the most influential frameworks in the strategic management literature. According to the RBV, each organization possesses unique resources which are different and distinguishable to those held by other ventures (Penrose, 1959; Peteraf, 1993; Wernerfelt, 1984). Resources include all assets, capabilities, processes, firm attributes, and knowledge controlled by an organization and they are generally internal to a firm (Barney, 1991: 101). Traditional organizations build competitive advantage by combining, developing, and utilizing these unique sets of resources to develop capabilities and strategies to improve efficiency and effectiveness (Barney, 1991; Bergmann-Lichtenstein \& Brush, 2001; Hansen \& Wernerfelt, 1989; Wernerfelt, 1984). Although many resources are developed internally, resources are also gained through external sources like partnerships. The RBV provides a theoretical framework to explain how nascent social ventures utilize partnerships to achieve resource conditions and implement social venture strategies that facilitate a competitive advantage.

Entrepreneurship is the process of identifying, acquiring, and accumulating resources to take advantage of perceived opportunities (Bergmann-Lichtenstein \& Brush, 2001). Traditional entrepreneurship literature shows that the success or failure of a new venture is affected by its resource profile (Greene \& Brown, 1997; Hoang \& Antoncic, 2003). 
Similarly the ability of nascent social ventures to address unmet social needs or opportunities and create social value is linked to their effectiveness in mobilizing and utilizing resources (Leadbeater, 1997; Waddock \& Post, 1991). Nevertheless, new ventures often face uncertainty and are highly vulnerable to environmental selection and liabilities of newness and smallness (Aldrich, 1999; Stinchcombe, 1965). Thus, they face constraints in their access to and control over resources (Aldrich \& Auster, 1986) which limit feasible strategic alternatives (Edelman, Brush, \& Manolova, 2005; Hofer \& Sandberg, 1987).

In order to carry out an entrepreneurial strategy, resource gaps need to be filled so that adequate resource conditions are met. Firms develop many resources internally (Barney, 1991). However, nascent ventures also overcome internal resource weaknesses through external mechanisms: market transactions, acquisitions (Makadok 2001), and strategic alliances or partnerships (Das \& Teng, 2000). Chance or luck also plays a role in the fulfillment of resources (Barney, 1986). A partnership enables a firm to access only the resources it needs, as compared to an acquisition where an entire firm is acquired (Das \& Teng, 2000). At the same time, through a partnership a venture protects its other resources by not giving other firms the opportunity to imitate their resources (Das \& Teng 2000). An example of a social venture partnership includes a microfinance organization partnering with a governmental entity to provide health services to their clients. RBV suggests that the purpose of any strategy is to enhance the value-creation potential of firm resources (Dierickx \& Cool, 1989; Wernerfelt, 1984). Sustainable competitive advantage hinges on whether certain resource conditions can be met. The 
combination of social venture partnerships and strategies assists in meeting these desirable resource conditions that lead to a competitive advantage (Teng, 2007).

Resource conditions. RBV suggests that resource conditions leading to a firm's efficiency and effectiveness need to be valuable, rare, imperfectly imitable, and not substitutable (Barney, 1991). Scholars have proposed a number of resource typologies that meet these resource conditions. Grant (1991) differentiates between tangible and intangible resources. Barney (1991) classifies resources into physical capital, human capital, and organizational capital. Hofer and Schendel (1978) suggest that a resource profile include financial, physical, managerial, human, organizational, and technological resources. This dissertation combines these classification models, focusing on financial, physical, human, and social capital resources which are important in the context of nascent entrepreneurial ventures (Aldrich, 1999). Since the operationalization of valuable, rare, imperfectly imitable, and not substitutable resources is not an easy task, this dissertation focuses on the heterogeneity of the resource combinations. Resource heterogeneity requires that not all firms possess the same amount and kinds of resources. The competitive advantage of the firm can be understood as a function of the combined value and heterogeneity of all firm resources and resource interactions (Lavie 2006). Thus in the context of the RBV heterogeneous resource conditions are important to obtain a competitive advantage. This study focuses on the role heterogeneous financial, physical, human, and social capital resources attained through partnerships play in nascent social venture development and value creation. 
Financial capital. A new venture must hire employees, obtain inputs, and develop products (Aldrich, 1999). Since these activities are costly and often take place before a nascent venture generates revenue from selling products or services, ventures must seek financing. Nascent social ventures have limited access to financial capital (Peredo \& Chrisman, 2006; Emerson \& Bonini, 2003) and like traditional entrepreneurial ventures they often must rely on the savings and personal assets of founders to build their organizations (Aldrich \& Martinez, 2001).

Nevertheless, external financing is also important to the new venture creation process (Shane \& Venkataraman, 2000; Venkataraman, 1997). External funding sources are often unavailable due to a venture's small size, unknown track record, and uncertain future (Liao, Welsch, \& Moutray, 2009). However, financing may be secured through partnerships with entities from the private, public, and social sector. For example, a social venture might receive a grant from a corporate or a government entity partner. Nascent social ventures rely upon a range of funding sources, including individual contributions, grants, venture philanthropy, loans, in-kind donations, member dues, user fees, and government payments from funders who have a wide range of motivations and expectations (Austin et al., 2006; Barendsen \& Gardner 2004; Emerson 2003; Van Slyke \& Newman 2006). These sources of capital often refer to themselves as partners as they provide a social venture funding, but also provide hands-on support and technical assistance (Austin et al., 2006). At the same time, social ventures may also partner with different entities to implement earned income activities. 
Physical capital. Physical capital resources include a venture's physical technology, equipment, geographic location, buildings, information technologies, and access to raw materials (Barney, 1991). Social ventures often attain physical capital through partnerships. For example, corporate and government partners often provide social ventures with in-kind donations and equipment, while social sector partners might share office space. Physical capital influences competitive outcomes (Harris \& Helfat, 1997) and is important to the development and success of a nascent social venture.

Human capital. Human capital represents the technical knowledge, productive skills, tacit knowledge, and know-how embodied in individuals critical to venture development (Barney, 1991; Becker, 1964), but often not easily imitable (Das \& Teng, 2000). These knowledge-based human capital resources are also attained outside a venture and they enable firms to effectively complete processes, accomplish tasks, and produce outcomes (Barney, 1991). For social ventures, human capital comes in the form of volunteers, staff, and managers as well as knowledge and assistance from partners. Volunteers usually take roles as board members or pro-bono consultants (lawyers, bankers, industry specialists), and offer day-to-day operational support in an organization. Many social ventures rely on volunteers to fill positions that would otherwise be covered by staff in the public or private sector. The ability to secure adequate human capital with specialized knowledge and technical skills enables social ventures to more effectively reach their value creation goals (Sharir \& Lerner 2006). 
Much nascent venture research focuses on the role of owner or founder human capital resources to firm performance (Cooper, Gimeno-Gascon, \& Woo, 1994; Edelman et al., 2005; Haber \& Reichel, 2007; Miller, 2009). In these studies human capital is assessed by examining the relationship between the entrepreneurs' education (Bird, 1989; Carsrud, Gaglio, \& Olm, 1987; Cooper et al., 1994; Robinson \& Sexton, 1994), prior experience, management skills (Bird, 1993; Cooper \& Gimeno-Gascon, 1992; Ronstadt, 1984), and venture performance. Founder's experience and management experience often predict traditional VC funding (Cooper et al., 1994; Hitt, Bierman, Shimizu, \& Kochhar, 2001), as well as venture growth and survival (Barringer, Jones, \& Neubaum, 2005; MacMillan, Siegel, \& Narasimha, 1985).

Although much of the entrepreneurship literature primarily focuses on human capital internal to firms, ventures also gain human capital through partnerships. Carsrud, Gaglio and Olm (1987) look external to ventures and find evidence that the size and content of an entrepreneur's network reflects the human capital resources available to a venture and its success. Turpin, Garrett-Jones and Diement (2005) assess the careers of scientists participating in cross-sector research and development collaboration who spread their knowledge through these partnerships. Bozeman and Corley (2004) examine how scientists acquire and deploy scientific and technical human capital through research collaboration with academics from similar and different universities.

Social capital. Social capital is an asset or resource embedded in relationships of individuals, communities, partnerships, networks or societies (Burt, 1997; Nahapiet \& 
Ghoshal, 1998). Social ventures use social capital gained through their network of relationships or partnerships to mobilize actual resources and gain access to other potential resources (Nahapiet \& Ghoshal 1998: 243). Social capital generally includes both structural and relational components. The structural dimension of social capital comprises the location of an actor's contacts within a network and how they are reached (Burt, 1992; Granovetter, 1992). The relational dimension focuses on the quality of relations or ties that an actor has, specifically those relations that influence behavior. The key facets of this relational dimension are trust (Fukuyama, 1995) and norms (Coleman, 1990). The network of social interaction ties creates opportunities for social capital transactions that lead to the accumulation of additional resources.

Social capital theory argues that the external networks of ventures provide access to resources that may contribute to their survival and performance (Adler \& Kwon, 2002). Social capital can be converted into tangible and intangible benefits or resources, including increased trust and cooperation from others, financial capital, physical assets, and other resources available at a lower cost than other alternatives (Kuratko \& Welsch, 2004). For example, Webb, Kistruck, Ireland and Ketchen (2009) analyze how the Commercial Bank of Zimbabwe establishes trust and builds social capital with local citizens through its partnership with the nonprofit organization CARE, and as a result is more easily able to expand into new product lines and towns within Zimbabwe. Social capital is an instrumental resource through which a social venture obtains financial support, gains legitimacy, acquires additional resources, and facilitates access to other markets. 
Partnerships. As suggested by the RBV, nascent social ventures face internal resource gaps (Teng, 2007). Thus, they must access resources outside the boundaries of the venture in order to develop adequate resource conditions and achieve their goals (Aldrich \& Martinez, 2001; Austin et al., 2006). One way social ventures address these resource gaps is through partnerships or strategic alliances (Googins \& Rochlin, 2000; Teng, 2007) with organizational entities from the same sector (Kanter, 1994; Das \& Teng, 2000) or different sectors (Googins \& Rochlin, 2000). The functional purpose of the partnership ranges from offering part of a service, to supplying a product or necessary material, to promoting a solution, to providing labor, funding, or technical assistance on how to use a product or service (Maase \& Doorst, 2007). Thus, a partnership can provide a means of developing strategic direction and scaling services that is impossible for any actor operating alone. Partnerships with diverse sectors facilitate the attainment of resource conditions that lead to a competitive advantage. Through partnerships a social venture can gain additional financial, human, physical, or social capital or access to markets that will make the venture more successful and outperform competitors.

In a partnership two or more organizations exchange something of value, and the partnership endures beyond a single transaction. The degree of partnership intensity ranges from loose collaboration (information sharing, program coordination, and joint planning) to more formal administrative consolidation and joint programming to complete integration through mergers or joint ventures (Arsenault, 1998; Kohm, La Piana, \& Gowdy, 2000). Gray (1989:5) describes collaboration as a "process through which parties who see different aspects of a problem can constructively explore their 
differences and search for solutions that go beyond their own limited visions of what is possible." Guo and Acar (2005) define collaboration as "what occurs when different organizations work together to address problems through joint effort." Das and Teng (2000) define strategic alliances as "cooperative relationships in which resources are shared and exchanged in the pursuit of mutual goals." This dissertation builds off these definitions and uses the term partnership to refer to a mutual exchange or sharing of resources between two or more organizations in order to maximize value creation.

Social venture partnerships involve two or more organizations from the same or distinct sectors (Meyskens, Carsrud, \& Cardozo, Forthcoming). The public, private, and social sectors are the primary actors in partnerships and each sector is composed of different entities, each driven by distinct motivations. The public or government sector includes government agencies, schools, universities, and other entities owned at least partially by the government. Each public sector entity is supported by taxation rather than through voluntary market exchange (Schaeffer \& Loveridge, 2002) and exhibits different levels of "publicness" (Bozeman \& Bretschneider, 1994). The public sector acts to meet the needs, general welfare, and interests of its constituents by supporting other sectors and by setting policy and legal parameters (Maase \& Bossink, 2010). The private or corporate sector includes corporations or businesses whose primary goal is to maximize economic returns. The private sector provides resources and know-how, and also creates employment opportunities, but profits are distributed to owners or stakeholders (Maase \& Bossink, 2010). 
The social sector operates outside the market or state and broadly describes all aspects of society that extend beyond the public sector and the private sector (Pharr, 2003). The social sector is often also referred to as the nonprofit, civil, or third sector (Drayton, 2002; Teegan, Doh, \& Vachani, 2004) and has often expanded where the public and private sectors fail to adequately address social problems. The social sector includes individual beneficiaries and citizens, as well as nonprofit, social, and non-governmental organizations like religious entities, foundations, community organizations, and social service organizations that represent various social interests (Fox, Interamerican Development Bank, Brakarz, \& Cruz Fano, 2005: 16-17). The primary goal of the social sector is to provide social value. In the social sector the profit is not distributed among those with an ownership interest (Maase \& Bossink, 2010). Entities from the different sectors partner with each other to reach their goals. Thus, social ventures partner with entities from the social sector, private sector, and public sector. For example, Seelos and Mair (2007) assess how the Norwegian telecommunication company partners with the microfinance organization Grameen Bank to take advantage of Grameen's network to distribute and sell mobile phones to the rural poor in Bangladesh.

Cross-sector partnerships between the public, private, and social sectors have been analyzed in a variety of contexts (Arsenault, 1998; Austin, 2000a \& 2000b; Austin et al., 2006; London \& Hart, 2004; Meyskens et al., Forthcoming; Rondinelli \& London, 2003; Waddock, 1988). Fox, Interamerican Development Bank, Brakarz, and Cruz Fano (2005) assess tripartite partnerships in urban revitalization in Latin America between the public, private, and social sectors. Waddell (2005) evaluates different frameworks and structures 
across the private, public, and social sectors at different levels of community, regional, and national societal organizing. Brown and Ashman (1996) analyze how government agencies from the public sector and nongovernmental organizations from the social sector cooperate to expand the impact of joint programs. Seelos and Mair (2005) discuss the interface between social ventures, corporate social responsibility (CSR) efforts, and public institutions and their potential for collaborating in support of sustainable development and value creation. As can be seen from these examples, cross-sector partnerships play an important role in social venture development, resource attainment, and success (Meyskens et al., Forthcoming).

Nevertheless, partnerships also have disadvantages. These different sectors often have fundamental differences in values, governance structures, and missions (Googins \& Rochlin, 2000), which can lead to misunderstandings, distrust, conflict, and premature failure in partnerships (Berger, Cunningham, \& Drumwright, 2004; Macdonald \& Chrisp, 2005; Rondinelli \& London, 2003). Thus, not all partnerships result in positive outcomes. Many complexities, difficulties, and challenges can emerge from same-sector or cross-sector partnerships between entities from the public, private, and social sectors (Anderson \& Jap, 2005; Frisby, Thibault, \& Kikulis, 2004; Hodge \& Greve, 2005; Huxham, 1996; Parise \& Casher, 2003; Provan, Isett, \& Milward, 2004; Wondolleck \& Yaffee, 2000). These challenges have been attributed to factors such as environmental constraints, diversity in organizational aims, communication barriers, and difficulties in developing joint modes of operating, power imbalances, mistrust, and logistical problems of working with geographically dispersed partners (Babiak \& Thibault, 2009). For 
example, Babiak and Thibault (2009) find evidence of structural and strategic challenges in cross-sector partnerships. Some partners are competing for similar resources and missions, and roles and responsibilities change over time.

Scholarly research also suggests that cross-sector partnership diversity often brings valuable resources to the social venture, while creating mutual benefit for the public, private, or social sector partner (Meyskens et al., Forthcoming; Rondinelli \& London, 2003). In this study, partnership diversity refers to engaging in a broad range of partnerships with entities from different sectors. The nature, complexity and challenges of social needs require multiple actors and resources to produce solutions (Gray, 1989), thus social ventures with greater partnership diversity will have access to more heterogeneous resources. Social ventures engage in partnerships with various sectors to broaden their resources (Meyskens et al., Forthcoming) and facilitate the achievement of their mission (Maase \& Doorst, 2007).

Partnerships create and capture dynamic value opportunities (Emerson \& Bonini, 2003), cost reduction, and improvement in distribution efficiency (Chesbrourgh, Ahern, Finn, \& Guerraz, 2006; Prahalad \& Hammond, 2002). Partnerships enable social ventures to pool resources to develop capabilities they could not afford to develop on their own. Such capabilities include investing in systems such as information technology for managing members, volunteers, and funders, or collaborating with other social ventures to deliver programs or services (Austin, 2000a; Austin et al., 2006). For example, the microfinance organization Women's World Banking built sector-wide networks for microfinance 
organizations to build joint knowledge and to strengthen the sector's ability to affect banking regulations (Austin et al., 2006; Austin \& Harmeling, 1999). The collaborative pooling of expertise and resources can solve intractable problems, reduce risk, and enhance performance in ways that confrontation or competition cannot (Child \& Faulkner, 1998).

The literature also shows that partnerships are important for commercial firms to accumulate resources and create wealth (Preston \& Donaldson, 1999; Kale, Dyer, \& Singh, 2001). Partnerships fulfill strategic needs (Eisenhardt \& Schoonhoven, 1996) including sharing risk and investment (Ring \& Van de Ven, 1992), acquiring resources, and developing economies of scale and scope (Contractor \& Lorange, 1988; Mohr \& Spekman, 1994). At the same time, organizational learning is augmented through the acquisition and exchange of skills and knowledge (Doz \& Hamel, 1998; Hamel, 1991) and results in the development of dynamic capabilities (Teece, Pisano, \& Shuen, 1997) and new competencies (Hamel, Doz, \& Prahalad, 1989). Firm legitimacy is enhanced when two organizations work together (Baum \& Oliver, 1991). This facilitates entry into new markets (Gulati, 1998; Porter \& Kramer, 2002) and increases market power (Eisenhardt \& Schoonhoven, 1996). Consequently, traditional partnerships can lead to a resource-based competitive advantage (Eisenhardt \& Shoonhoven, 1996; Porter \& Kramer, 2002; Singh \& Mitchell, 1996). This study seeks to show that social venture partnerships can create a competitive advantage as well. 
In today's society socially driven cross-sector partnerships are becoming a powerful alternative to gain strategic and collaborative advantage, to mobilize resources, to raise the profile of the organizations involved, and to generate income (Di Domenico \& Haugh, 2007). This dissertation seeks to assess this role of partnership diversity in attaining a competitive advantage for social ventures.

Competitive advantage. Competitive advantage generally refers to the advantages of a firm which enable it to outperform competitors (Porter, 1985). A traditional commercial venture achieves a competitive advantage by developing certain combinations of resources that assist in achieving superior performance (Barney, 1991). Nascent ventures face unique challenges in mobilizing resources and crafting strategies that best utilize their resource base. Nevertheless, the possession of superior resources alone is not sufficient to create competitive advantage. Instead, managers execute strategies that exploit these resources in ways that synergistically leverage resource value (Penrose 1959). In the context of nascent social ventures, partnership diversity facilitates the development of earned income, innovation strategies, and adequate heterogeneous resource conditions that lead to a competitive advantage.

Commercial ventures are largely driven by profits (Knight, 1921; Schumpeter, 1934; Kirzner, 1973) and their performance is typically measured by financial returns (Austin et al., 2006). However, measuring nascent venture competitive advantage is a difficult task since no consensus exists as to what constitutes entrepreneurial success (Brush \& VanderWerf, 1992; Gruber, 2007). Although social venture success is often measured 
by assessing a venture's triple bottom line or blended value (Emerson \& Bonini, 2003), measurement methods differ across social ventures and can not be captured in a single variable like revenue. As a result, this dissertation defines competitive advantage as the potential for a social venture to create value, achieve venture development activities, and launch.

Since the primary focus of social ventures is to achieve their social purpose, the ability of a social venture to generate more competitive advantage is influenced by its ability to create economic, social, and environmental value. Economic value suggests that a social venture or its service or product must be of a certain quality or meet a market need in order to develop revenue. Economic value also represents tangible benefits for the social venture beneficiary or customer including cost savings or improved product performance (Fitzpatrick \& Gedaka 2003). If these economic benefits are achieved, the venture is more likely to achieve entrepreneurial rents, and environmental and social value often results as an externality. At the same time, environmental and social value creation is often a social venture's primary goal. Environmental value is often created by a social venture in the form of recycling or positively impacting the environment. Social value relates to improving quality of life by supporting health, education, community development, and other social benefits. A social venture that has the potential to achieve more social value has a competitive advantage over other types of social ventures.

Just as value creation is important for a social venture to attain a competitive advantage, for a nascent venture the achievement of different milestones is important in order to 
develop as a sustainable enterprise and eventually launch or start operations. New ventures do not emerge suddenly or spontaneously, but require a great many activities that represent firm development (Carsrud \& Brännback 2007; Reynolds \& Curtin 2008). These activities establish the physical structure and organizational processes of a new firm (Bhave 1994; Delmar \& Shane 2003). These activities include hiring an employee or lawyer, receiving funding, building a website, implementing a pilot project, securing a client, incorporating as a legal entity, and opening a bank account. The Panel Study of Entrepreneurial Dynamics (PSED) develops a framework of these activities to better understand nascent venture growth. Nascent ventures are in the process of development and different activities represent success or a competitive advantage compared to other ventures. Given the nascent status of early stage ventures, performance is influenced by a venture's ability to achieve activities that represent venture development (Gartner, Shaver, Carter, \& Reynolds, 2004). Nascent social ventures that are able to achieve more venture development activities have an advantage over other ventures as these activities indicate they are further developed, are more likely to launch, and are more likely to reach their social value creation goals.

Thus, in the context of nascent social ventures, competitive advantage is not related to the ability to achieve greater profit, rather it is based on the ability to create greater value, achieve more venture development activities, and launch. 


\section{CHAPTER 3: HYPOTHESIS DEVELOPMENT}

\section{Social ventures, partnerships, resource conditions, and competitive advantage}

Organizational research has extensively examined how nascent commercial ventures are constrained by the low level of resources they either own or control (Aldrich, 1999). Due to liabilities of newness (Stinchcombe, 1965) and smallness (Baum, 1996), nascent ventures lack access to sufficient financial, physical, social, and human capital resources. At the same time, social ventures are notoriously resource-strapped (Brown \& Kalegaonkar, 2002), which is not a surprise given that the primary goal of social ventures is not related to making a profit. However, from a strategy perspective, resources are important to achieving a competitive advantage (Barney, 1986; 1991). Thus, nascent ventures couple internal strengths with external resources to address these resource gaps. Partnerships serve as a particularly important strategy in reducing resource scarcity (Dubini \& Aldrich, 1991; Teng, 2007).

Nascent ventures require resources to develop and grow (Scott, 1987). Brush, Manolova, and Edelman (2008) empirically examine the properties of 646 nascent U.S. ventures and find that human, financial, and physical capital resources are necessary for short-term venture survival. Davidsson and Honig (2003) assess the impact of human and social capital in nascent ventures in Sweden in a large scale study and find that social capital is particularly important for successful emergent activity. Haber and Reichel (2007)

examine 305 small tourism ventures in Israel and find that human, physical, and 
organizational capital contributed respectively to venture development and performance in the short and long term. Nascent social ventures, like their commercial venture counterparts, require resources to develop and to achieve their value creation goals (Austin, 2000; Austin et al. 2006; Meyskens et al., Forthcoming).

Social ventures operating under nonprofit, for-profit, and hybrid legal forms (Townsend \& Hart, 2008; Neck et al., 2009) engage in partnerships to access different types of resources (Meyskens et al., Forthcoming). Cross-sector social partnerships provide a means for entities from the social, private, and public sector to gain resources (Seitanidi, 2008) and reduce the need to compete for resources (Grønbjerg, 1993; Guo \& Acar, 2005; Pfeffer \& Salancik, 1978; Saidel, 1994). Partnerships serve as an important strategy for nascent social ventures to leverage resources outside organizational boundaries (Austin et al., 2006). Di Domenico and Haugh (2007) survey 107 social ventures in the United Kingdom and find that the majority are involved in at least one dyadic partnership and have partnerships with multiple organizations. These partnerships facilitate the achievement of strategic objectives, increase the ability to learn and improve knowledge, to raise the venture's profile, and to increase income. Gazley and Brudney (2007) conduct surveys of 311 nonprofit executives in Georgia and find that nonprofit entities partner with public entities in order to secure scarce financial resources. Van Slyke and Newman (2006) examine a social entrepreneur who engages in extensive public-private partnerships in order to leverage resources to redevelop a poor area. These studies suggest that partnerships are an important strategy to address resource gaps for all types of nascent social ventures, regardless of their legal structure. Thus: 
Hypothesis 1a: Partnerships are important for all types of nascent social ventures.

Nevertheless, the achievement of a competitive advantage varies depending on the legal structure of a social venture. In the context of nascent social ventures, competitive advantage refers to the ability to develop as a venture, actually launch, and create value. Nonprofit ventures can turn to outside sources for donations, volunteers, and other assistance that facilitate the development of a competitive advantage. For example, a nonprofit social venture might seek financial capital from a variety of sources or fundraising initiatives and also turn to volunteers to develop a strategic plan or provide support as a board member. In addition, as a nonprofit entity they might be able to acquire access to a physical space in which to operate or computers to use for free. Access to these resources facilitated by nonprofit status, can help a nonprofit social venture develop and launch. For-profit social ventures might get access to grants, volunteers, or physical capital. However the incentive for outside sources to provide these resources are less, since for-profit entities can not provide the same type of tax benefits or social cache as a nonprofit social venture. Hybrid social ventures have both nonprofit and for-profit components. Thus, they gain the benefits and drawbacks of each type of legal structure. However, a nonprofit social venture has greater access to these external sources that facilitate competitive advantage. Thus:

Hypothesis 1b: Nascent nonprofit social ventures have a greater competitive advantage than hybrid or for-profit social ventures. 


\section{Partnerships, resources conditions, and competitive advantage}

Partnerships between organizations from the same-sector and across-sectors have been analyzed extensively in the literature. Most studies assess a social venture's singular partnership with another social venture or across sectors with a public sector or government entity (Powell \& Clemens, 1998) or a private sector entity or corporation (Austin, 2000). However, these studies often only examine one type of partnership with a single social venture, corporation or government entity is examined (Austin, 2000; 2006). In reality, social ventures have a diverse array of partnerships with different types of organizations from public, social, and private sectors operating at the same time (García-Canal, Valdéz-Llaneza, \& Ariñio, 2003; Gray, 1989; Hodge \& Greve, 2005). The interplay of these partners from different sectors facilitates the development of heterogeneous resource conditions (Preston \& Donaldson, 1999; Kale et al., 2001) that are necessary to attain a competitive advantage. Nevertheless, relatively few studies assess the complex, dynamic interchange of multiple cross-sector partnerships.

A robust array of partnerships provides access to a diverse set of financial, human, physical, and social capital resources. In the context of social ventures, these resources include funding, board members, management, staff, volunteers, space, equipment, marketing, endorsement, and access to other resources. Partnerships help organizations acquire resources that cannot be produced internally (Afuah, 2000; Dyer \& Singh, 1998;

Hamel, 1991; Hamel et al., 1989; Hennart, 1988; Teece, 1986; Williamson, 1991), but 
which are needed to survive in a highly competitive environment. Strategic alliances can provide an important legitimizing function for their members (Dacin, Oliver, \& Roy, 2008). Of particular importance are resources that help the organization develop distinctive capacities (Barney, 1991; Ghemawat, 1986; Peteraf, 1993; Prahalad \& Hamel, 1990). Thus, a firm can develop more heterogeneous resource conditions by having a diverse set of partnerships with entities from different sectors.

The relationship between partnerships and resources has been examined primarily in the context of commercial ventures. Premaratne (2001) find that networks of partnerships provide important resources to ventures in Sri Lanka. Carsrud, Gaglio, and Olm (1987) find evidence that the size and content of an entrepreneur's network reflects the resources available to a venture. Bretherton and Chaston (2005) interview small and medium sized wineries in New Zealand and find that they engage in strategic partnerships to gain access to scarce resources and capabilities at different points along the value chain. Nevertheless, given the strategic motivations to attain heterogeneous resources through partnerships (Ho Park \& Zhou, 2005) one would also expect a nascent social venture to derive similar access to a variety of resources when partnering with multiple entities from different sectors. Thus,

Hypothesis 2a: Partnership diversity is positively associated with heterogeneous resource conditions.

Sustainable competitive advantage hinges on whether heterogeneous resource conditions can be met (Barney, 1991). In the context of commercial ventures, competitive 
advantage is often reflected as profitability, sustainability, and survival. For example, Haber and Reichel (2007) argue that human, organizational, and physical capital resources affect small venture sustainability in the context of the tourism industry. Honig (1998) finds that social capital generally increases the profitability of microbusinesses in Jamaica. Dyer and Singh (1998) propose that interorganizational complementary resources and capabilities lead to a competitive advantage. Rodan and Galunich (2004) find that access to heterogeneous knowledge is important for a venture. In the context of this dissertation, competitive advantage refers to nascent social venture economic, social, and environmental value creation as well as venture development.

The development of a diverse array of resources can lead to greater value creation, venture development, and eventual launch. Meyskens, Carsrud and Cardozo (Forthcoming) develop a conceptual framework which shows how partnerships with corporations, government, and other social ventures are related to the accumulation of resources that lead to different types of value creation. Resource based theory suggests that resource heterogeneity is necessary for a competitive advantage (Barney, 1991; Alvarez \& Busenitz, 2001). Thus:

Hypothesis 2b: Heterogeneous resource conditions are positively associated with a competitive advantage.

Partnerships assist in meeting these desirable resource conditions that lead to a competitive advantage (Teng, 2007). The previous two hypotheses suggest a positive 
relationship between partnership diversity and heterogeneous resource conditions as well as heterogeneous resource conditions and a competitive advantage. These hypotheses suggest a direct link exists between partnership diversity and competitive advantage.

Many studies confirm the important role that partnerships or networks play in influencing entrepreneurial processes and outcomes that affect competitive advantage (Jack, 2010). Network formation is important for venture growth (Carsrud et al., 1987; Donckels \& Lambrecht, 1995; 1997). Zhao and Aram (1995) find that high-growth firms use networks more intensely than low-growth firms. Davidsson and Honig (2003) find that strong ties in the early start-up phase influence nascent entrepreneurs to continue in their formation activities. Lee, Kyungmook, and Pennings (2001) find that external links to venture capitalists predict start-up performance. Galaskiewicz, Bielefeld, and Dowell (2006) find that networks are important for organizational growth over a fourteen-year time period.

The diversity of partnerships further impacts performance and success (Googins \& Rochlin, 2000; Rondinelli \& London, 2003). Partnerships with different types of public, private, and social sector entities facilitate a venture in reaching their goals and enhance a social venture's capacity to generate greater social value (Di Domenico \& Haugh, 2007). The cooperation of multiple and diverse actors, each with its own perspective and comparative advantages, helps move organizations beyond the status quo (Brown \& Ashman, 1996; Brinkerhoff, 2002). In fact, Huxham (1996) describes the concept of 'collaborative advantage' as the role collaborations play in helping nonprofits build 
distinctive capabilities to address social problems. Maase and Doorst (2007) find that more complex multiple sector networks facilitate the development of a pilot project. Sharir and Lerner (2006) find that social networks are one of the top three determinants of success of social ventures operating in social settings in Israel. Building collaborative relationships to implement social initiatives is often crucial for success (Pearce \& Doh, 2005). Miller (2009) also shows the importance of networks, both formal and informal, to a social venture's development and success. Thus:

Hypothesis 2c: Partnership diversity is positively associated with a competitive advantage.

At the same time, these prior studies and hypotheses suggest that:

Hypothesis 2d: Heterogeneous resource conditions mediate the relationship between partnership diversity and a competitive advantage.

In summary, partnerships help fill the resource gaps faced by social ventures. A diverse array of different types of partnerships with entities from the public, private, and social sectors assists in the development of the appropriate heterogeneous resource conditions that lead to social venture development, launch, and value creation. This facilitates the development of a competitive advantage. 


\section{Partnerships, strategies, and competitive advantage}

Partnerships also facilitate the development of strategies that lead to a competitive advantage by facilitating the transfer of existing knowledge from one organization to another (Dyer \& Nobeoka, 2000; Grant \& Baden-Fuller, 1995; Mowery, Oxley, \& Silverman, 1996). For example, Su, Tsang and Peng (2009) assess the impact of external partnerships on product and process innovativeness for Taiwanese bio-technology firms and find that only partnerships with universities and research institutes add value compared to competitors, suppliers, and customers. At the same time, through partnerships social ventures are able to create new knowledge and innovative ideas that neither of the collaborators previously possessed (Gulati, 1998; Mowery et al., 1996). This leads to social innovation or "a novel solution to a social problem that is more effective, efficient, sustainable, or just than existing solutions. In social innovation the value created accrues primarily to society as a whole rather than to private individuals" (Phills, Deiglmeier, \& Miller, 2008: 39). Since innovation is a process and a product (Phills, et al., 2008), partnerships serve as a means to facilitate the process of strategic social innovation that can result in a more innovative product or outcome.

Social ventures are challenged to develop more innovative means to solve social problems (Dees, 1998; Drayton, 2002; Light, 2006; Mair \& Marti, 2006). Increasing donor fatigue has also led supporters to seek out more innovative organizations that create social value (Leadbeater, 1997). Social innovation can be sustaining or catalytic (Le Ber \& Branzei, 2010). Sustaining innovations can be incremental quality or functionality improvements or breakthrough products or services that leapfrog existing 
technologies (Christensen, Baumann, Ruggles, \& Sadtler, 2006). Catalytic innovations disrupt the status quo (Anthony, Johnson, Sinfield, \& Altman, 2008) through changes in functionality of technologies, different business models, or systemic reform (Christensen, Grossman, \& Hwang, 2009).

Strategic alliances that combine complementary core competencies can create new resource constellations that enable innovative solutions to long-standing social and economic problems. This leveraging of distinct organizational capabilities and resources produces powerful co-generation of social and economic value (Austin 2000; Austin, Reficco, Berger, Fischer, Gutiérrez, Koljatic, M., et al., 2004; Kanter 1999). Strategic alliances also seem to be critical to the success of emerging innovative business strategies with low income sectors with low income market segments operating at the bottom of the pyramid (Prahalad, 2005; Rangan, Quelch, Herrero, \& Barton, 2007).

A diversity of partnerships with entities from the public, private, and social sectors can facilitate the development of innovative social venture strategy (Doz \& Hamel, 1998; Di Domenico \& Haugh, 2007; Meyskens et al., 2010). Hart and Shartma (2004) analyze social ventures working with the poorest sectors of society that form partnerships with many different partners from the public, private, and social sectors to create technological solutions to social problems. Le Ber and Branzei (2010) assess the relational processes that underpin social innovation within strategic cross-sector partnerships by examining how partners' interactions sustain success or precipitate failure in the context of partnerships in the Canadian health care domain. Bloom and Smith (2010) suggest that 
alliances are one of the factors important for social venture scaling. Tapsell and Woods (2008) examine how the Maori communities integrate themselves in both social and economic entrepreneurial activity to develop social innovation in an indigenous context. Social ventures partner with a diverse range of actors to engender and facilitate the development of social innovation (Hess, Rogovsky, \& Dunfee, 2002; Waddock, 1988). Thus:

\section{Hypothesis 3a: Partnership diversity is positively related to social innovation.}

Partnerships with a diverse range of entities from the public, private, and social sectors are not only important in developing socially innovative strategies, but also as a means to develop earned income strategies. Many of these earned income strategies are also innovative. Earned income represents financial revenues generated for services, programs, or products provided by a social venture which also enable social venture beneficiaries or clients to enhance their own wealth and improve their standard of living (Nicholls, 2006). In an environment of limited resources, earned income serves as a means to reduce dependency on other funding organizations and it can result in a more sustainable social venture. These earned income strategies include contracts with governments, fee-based work for corporations (Dees, 1998; Dees \& Anderson, 2003), and products or services such as museum gift shops, organizational consulting, hospital parking lots, and microfinance loans (Dart, 2004). However, they also include causerelated marketing, leasing land, and fulfilling government contracts. Thus, social 
ventures have increasingly developed their own sources of revenue to fund operations (Dees, 1998; Dees \& Anderson, 2006).

A diverse range of different types of partnerships facilitates the development and implementation of earned income strategies. Thus:

Hypothesis 3b: Partnership diversity is positively related to earned income.

These social venture innovation and earned income strategies impact the performance of social ventures. Social innovation represents the cost side of a venture and earned income represents the revenue side. Social ventures must invest in developing innovative technologies, products, services, and strategies. However they often develop social innovation strategies to increase the depth or impact of their services and benefit more individuals. Developing earned income strategies also require human and financial capital to develop, but hopefully they will directly produce revenue and make it easier for a social venture to reach their goals. Nevertheless, the ultimate outcomes of both social innovation and earned income strategies can range from improving the life conditions of disenfranchised individuals to meeting unmet basic needs for society as a whole (Austin, Gutiérrez, Ogliastri, \& Reficco, 2006; Brickson, 2007). As a result, social ventures that develop and implement social innovation and earned income strategies are more likely to facilitate the development and launch of a venture and create greater value, the factors that lead to competitive advantage in nascent social ventures. Weerawardena and Mort (2001) argue that social ventures attain a competitive advantage through innovative 
strategies and learning capabilities. Innovative social ventures can achieve revolutionary breakthroughs, catalytic change, and greater social value (Seelos \& Mair, 2005; Waddock \& Post, 1991 \& 1995). Kourula and Halme (2008) suggest that partnerships between social ventures and corporations seek to use innovative new business models to develop new products or services to solve social and environmental problems. Thus,

Hypothesis 3c: Social venture innovation and earned income strategies are positively related to a competitive advantage.

In summary, sustainable competitive advantage is related to whether certain heterogeneous resource conditions can be met and to whether nascent social ventures can develop earned income and social innovation strategies. A diversity of partnerships facilitates in the development of heterogeneous resource conditions and social venture strategies that lead to a competitive advantage (Teng, 2007). 


\section{CHAPTER 4: METHODOLOGY}

The relationships between partnerships, resource conditions, social venture strategies, and a competitive advantage are analyzed in the context of nascent social ventures that participated in business plan competitions. Given the different types of social ventures and relative newness of the phenomenon, analyzing ventures that participated in these competitions provides a convenience sample of social ventures at earlier stages of development. As part of the methodology, different types of partnerships, resources, strategies, and other characteristics of social ventures are operationalized based on the content analysis of the business plans through human and computer aided coding. A follow-up survey facilitates the measurement of a competitive advantage. Finally, different statistical methods, including correlations, t-tests, ANOVA, regression, and nonparametric statistics are used to analyze these relationships.

\section{Sample}

The sample consists of nascent social ventures that submitted full business plans to business plan competitions sponsored by universities and nonprofit organizations based in the United States from 2005 to 2009. Most social venture business plan competitions form part of the general increase in educational initiatives in social entrepreneurship. These competitions offer a broad range of workshops, mentors, and other facets of support to their participants through a comprehensive six month process. Social venture competitions vary in form, scope, and purpose. The business plans and ventures 
developed as part of these competitions are generally required to be in the start-up phase in development, and they must focus on addressing social and/or environmental problems. An example of the type of social venture common in a social venture business plan competition is Telenua which provides wireless phone service to the poor in Kenya. The Telenua business plan is available on the Brigham Young University website (http://socialventure.byu.edu/docs/TelenuaBusinessPlan.pdf).

Business plan competitions. Social venture business plan competitions are generally hosted by business schools and focus only on business students, but some are offered by other schools and departments within a university (Schlee, Curren, \& Harich, 2009). In most cases these competitions require at least one student from the respective university to be a primary member of the team. However a few competitions are more open. Some competitions have broader eligibility requirements and are focused on social ventures in general (Business in Development Challenge, Global Social Venture Competition, Tulane Business Plan Competition, University of Washington, and the William James Foundation Socially Responsible Competition), while others are more focused on cleantechnology (California Clean Tech Open, Carnegie Mellon Sustainable Technology Track, Colorado at Boulder Cleantech Innovation Challenge, Ignite Clean Energy Competion, the MIT Clean Energy Prize).

Business plan competitions have been the source of research data in other studies and also as a setting to test theory. Friar and Meyer (2003), for instance, identify factors differentiating high-growth ventures from micro-ventures by analyzing business plans 
submitted to a business plan competition in Boston. Similarly, Foo, Wong, and Ong (2005) analyze the impact of team diversity on the judges' evaluation of the team's ideas in a business plan competition, using the judges' evaluation as a proxy for success, and Wen and Chen (2007) study the innovation process in teams participating in a business plan competition. Finally, Kirsch, Goldfarb, and Gera (2009) assess the role of business plans in venture capital decision making by analyzing a sample of 722 funding requests submitted to an American venture capital firm.

Much existing research using business plans focuses on assessing the influence of business planning on commercial venture success and the results suggest mixed findings. Lange, Mollov, Pearlmutter, Singh, and Bygrave (2007) survey Babson College alums from over fifteen years. They find no significant difference between the performance of ventures started by alum that had business plans and those that did not. Honig and Karlsson (2004) find that venture survival is unrelated to business planning. However, Delmar and Shane (2003) find a positive correlation between outcomes and business planning. Although these results are mixed, other research has found that the process of business planning is really what is important for venture development (Carsrud \& Brännback, 2007). Nevertheless, these studies focus on assessing the impact of business planning which is not the focus of this dissertation. They are mentioned merely to show the prevalence of using business plans as a means to assess entrepreneurial ventures and their processes. 
Data collection. As part of the dissertation, a list of universities and nonprofit organizations hosting social venture business plan competitions was compiled after formal permission was received to conduct this research by the Institutional Review Board in October 2008 (see Appendix 1; renewal in October 2009 - Appendix 2; and amendment in March 2010 - Appendix 3). The original list contained 39 social venture business plan competitions obtained in December 2008 from the website of the William James Foundation, an organization which sponsors one of the primary social venture business plan competitions ${ }^{1}$. This business plan competition list was later complemented with other business plan competition lists from the Social Entrepreneurship Handbook, the Global Social Venture Competition, and the Green $\mathrm{VC}^{2}$. In total, 45 competitions were researched to determine if they had a social venture competition or a social venture track in a traditional business plan competition. These competitions represented 28 universities, 15 nonprofit organizations, one corporation, and one multilateral entity. After initial internet research to eliminate non-pertinent competitions, 38 of these 45 competition sponsors were invited to participate in this research. After additional research and email follow-ups, only 26 competitions were found to have a social venture focus and be based in the United States.

Table 2 details the 19 business plan competitions that were deemed as not relevant to pursue a relationship for this dissertation research as they did not have a website, catered

\footnotetext{
${ }^{1}$ http://www.williamjamesfoundation.org/index.cfm?fuseaction=Page.viewPage\&pageId=515\&parentID=489\&nodeID=1

${ }^{2}$ http://www.gsvc.org/index.cfm? fuseaction=Page.viewPage\&pageId=200\&parentID=58\&nodeID $=1$ and http://www.greenvc.org/business-plan-competitions.html
} 
Table 2: Social venture business plan competition sponsors - Not relevant

\begin{tabular}{|c|c|c|c|c|c|c|}
\hline Name & Website & Sponsor Type & Why Not Participate & Collect & \# Plans & \# Years \\
\hline 1 Business Environmental Awards & http://www.acterra.org/bea/index.html & Non-Profit & No business plan required & $\mathbf{0}$ & NK & NK \\
\hline 2 Connecticut Venture Group & http://www.cvg.org/contest & Non-Profit & No social venture track & 0 & NR & NR \\
\hline 3 Echoing Green & http://www.echoinggreen.org/fellowship & Non-Profit & No business plan required & 0 & NR & NR \\
\hline 4 Eileen Fisher's Women-Owned Business Grant & http://www.eileenfisher.com & Corporation & No business plan required & 0 & NK & NK \\
\hline 5 Ignite Clean Energy Competition & http//www.ignitecleanenergy.com & Non-Profit & Referred to MIT & 0 & NK & NK \\
\hline 6 Licensing Executives Society Foundation Graduate Competition & http://www.lesfoundation.org/graduate_student & University & No social venture track & 0 & NK & NK \\
\hline 7 NESsT Social Enterprise Competition 2007 & http://www.nesst.org/competition/ & Non-Profit & Not interested - too busy & 0 & NR & NR \\
\hline 8 Oxford University 21 st Century Challenge & http://www.sbs.ox.ac.uk/21challenge & University & Organizer on sabbatical & 0 & NK & NK \\
\hline 9 Private Sector Development Research Competition & http://www.ifc.org/competition & Multilateral & No business plan required & 0 & NR & NR \\
\hline 10 Rice University Business Plan Competition & http://www.alliance.rice.edu/alliance/RBPC & University & No Response & 0 & NK & NK \\
\hline 11 San Diego State University Venture Challenge & http://www-rohan.sdsu.edu/dept/emc/programs/Venture-Challenge/ & University & No social venture track & 0 & NR & NR \\
\hline 12 Skoll Awards for Social Entrepreneurship & http://www.skollfoundation.org/skollawards/index.asp & University & Organizer on sabbatical & 0 & NK & NK \\
\hline 13 Social Enterprise Club Pitch for Change Competition & http://www.socialenterpriseclub.com/conference/pitchforchange.html & University & Referred to HBS contest & 0 & NK & NK \\
\hline 14 Social Innovation Forum & http://www.socialinnovationforum.org & Non-Profit & Nonprofits in Boston & 0 & NK & NK \\
\hline 15 (SAGE) World Cup & http://www.sageglobal.org & Non-Profit & High school students & 0 & NK & NK \\
\hline 16 Technoserve & http://www.technoserve.org/ & Non-Profit & For small businesses & 0 & 3000 & 6 \\
\hline 17 UCLA & http://www.anderson.ucla.edu/x10064.xml & University & No social venture track & 0 & NR & NR \\
\hline 18 Competition & http://www.usfca.edu/sobam/nvc/bpc/ & University & No response & 0 & NK & NK \\
\hline \multirow[t]{2}{*}{19 Youth Social Enterprise Initiative } & http://www.ysei.org & Non-Profit & No business plan required & 0 & NK & NK \\
\hline & & & & 0 & 3000 & \\
\hline
\end{tabular}

* NK = Not Known; NR - Not Relevant

Many of these sponsoring entitties did not require a business plan (5), did not have a social venture track (4), referred me to another entity (2), were for a different type of business (3),

or were not interested as organizer was on sabbatical, plans were for their students only, they did not respond, or they were too busy(5) 
Table 3: Social venture business plan competitions

\begin{tabular}{|c|c|c|c|}
\hline Name* & Start** & Type & Eligible \\
\hline 1 Ashoka Citizen Base Awards & NA & Competition & NA \\
\hline Ashoka Argentina & 2006 & Competition & Argentine social ventures \\
\hline Ashoka-McKinsey Brazil & 2000 & Competition & Brazilian social ventures \\
\hline 2 Baruch College \& ML Entrepreneurship Competition & 2007 & Track & NYC Students \\
\hline 3 Business in Development Challenge & 2005 & Competition & Any venture \\
\hline 4 Brigham Young University & 2004 & Competition & BYU Students \\
\hline 5 California Clean Tech Open & 2006 & Competition & U.S. resident/citizen \\
\hline 6 Carnegie Mellon McGinnis Venture Competition & 2007 & Track & One graduate student \\
\hline 7 Cleantech Innovation Challenge -U. Colorado at Boulder & 2006 & Competition & One graduate student \\
\hline 8 Duke Start Up Challenge & 2002 & Track & One Duke student \\
\hline 9 Florida International University Entrepreneur Challenge & 2008 & Track & One FIU student \\
\hline 10 Global Social Venture Competition & 2000 & Competition & One graduate business student \\
\hline 11 Gonzaga University Hogan Entrepreneurial Program & 2007 & Track & Participating university student \\
\hline 12 Harvard Business School Business Plan Contest & 2001 & Track & Harvard graduate student \\
\hline 13 Investor Circle & 1992 & Venture Fair & U.S. based for-profit firm or subsidiary \\
\hline 14 MIT \$100K Competition & 2006 & Track & Full-time student from northeast \\
\hline 15 Notre Dame Social Venture Competition & 2002 & Competition & One Notre Dame student or alum \\
\hline 16 NYU - Leonard Stern School of Business & 2004 & Track & One NYU student or alum \\
\hline 17 Seattle Pacific University Social Venture Plan Competition & 2007 & Competition & One SPU student \\
\hline 18 Social Venture Captial Investment Competition & 2006 & Competition & Full-time MBA students \\
\hline 19 Stanford's Social E-Challenge & 2007 & Competition & One Stanford student or alum \\
\hline 20 Tufts Entrepreneurship Business Plan Competition & 2005 & Track & One Tufts student \\
\hline 21 Tulane Business Plan Competition & 2007 & Track & One student from accredited university \\
\hline 22 Social Innovation Competition & 2007 & Competition & All student teams \\
\hline 23 University of Michigan - DTE Clean Energy Prize & NA & Competition & One Michigan student \\
\hline 24 University of Washington GSEC & 2005 & Competition & Student must present \\
\hline 25 William James Foundation Socially Responsible Competition & 2004 & Competition & For profit social enterprises \\
\hline 26 Yale Entrepreneurial Society (YES) & 2007 & Track & One Yale student or faculty member \\
\hline
\end{tabular}

* Name starts with the University sponsor of the competition. In many cases a corporate sponsor was also part of the formal compettion name. ** Start year generally represents the first year the final round of the competition took palce. Ex. If the competition first launched during 20052006, the start years would be 2006

NA $=$ Not Available 
Table 4: Social venture business plan competition sponsors - Relevant

\begin{tabular}{|c|c|c|c|c|c|c|c|c|}
\hline Name & Website & Sponsor Type & Status & Collect & \# Plans & \# Years & Email & Rrate \\
\hline 1 Ashoka Citizen Base Awards & http://www.citizenbase.org/bp_competitions & Non-Profit & Meeting & 0 & NK & NK & $\mathrm{NA}$ & NA \\
\hline Ashoka Argentina & http://www.ashoka.org/argentina & Non-Profit & Meeting & 0 & 15 & 3 & NA & NA \\
\hline Ashoka-McKinsey Brazil & http://www.empreendedorsocial.org.br/ & Non-Profit & Send Email & 6 & 65 & 7 & 7 & $86 \%$ \\
\hline 2 Baruch College \& ML Entrepreneurship Competition & http://zicklin.baruch.cuny.edu/bcec/college & University & Gave Emails & 2 & 6 & 2 & 6 & $33 \%$ \\
\hline 3 Business in Development Challenge & http://www.bidnetwork.org/set-44007-en.html & Non-Profit & Meeting & 0 & 500 & 3 & NA & NA \\
\hline 4 Brigham Young University & http://socialventure.byu.edu/ & University & Gave Emails & 6 & 38 & 6 & 38 & $16 \%$ \\
\hline 5 California Clean Tech Open & http://www.cacleantech.org & Non-Profit & Gave Emails & 21 & 112 & 3 & 150 & $14 \%$ \\
\hline 6 Carnegie Mellon McGinnis Venture Competition & http://mcginnisventurecompetition.com & University & Gave Emails & 2 & 2 & 3 & 2 & $100 \%$ \\
\hline 7 Cleantech Innovation Challenge -U. Colorado at Boulder & http://leeds.colorado.edu/Centers_of_Excellence/ & University & Gave Emails & 2 & 8 & 5 & 8 & $25 \%$ \\
\hline 8 Duke Start Up Challenge & http://www.dukestartupchallenge.org/contact & University & No Response & 0 & NK & NK & NA & NA \\
\hline 9 Florida International University Entrepreneur Challenge & http://fiuchallenge.com & University & Gave Emails & 10 & 15 & 2 & 15 & $67 \%$ \\
\hline 10 Global Social Venture Competition & http://www.gsvc.org/ & University & Send Email & 0 & 500 & 10 & NA & NA \\
\hline 11 Gonzaga University Hogan Entrepreneurial Program & http://www.gonzaga.edu/ & University & Gave Emails & 12 & 42 & 3 & 42 & $29 \%$ \\
\hline 12 Harvard Business School Business Plan Contest & http://www.hbs.edu/entrepreneurship/bplan/ & University & Not Intersted & 0 & 500 & 10 & NA & NA \\
\hline 13 Investor Circle & http://www.investorscircle.net/ & Non-Profit & No Response & 0 & NK & NK & NA & NA \\
\hline 14 MIT Entrepreneurship Competition & http://web.mit.edu/ideas/www/index.htm & University & Send Email & 3 & NK & NK & 36 & $8 \%$ \\
\hline 15 Notre Dame Social Venture Competition & http://www.nd.edu/ entrep/svindex 1.html & University & Not Interested & 0 & NK & NK & NA & NA \\
\hline 16 NYU - Leonard Stern School of Business & http://w4.stern.nyu.edu/berkley/bpc.cfm?doc_id=6306 & University & Meeting & 1 & 150 & 5 & NA & NA \\
\hline 17 Seattle Pacific University Social Venture Plan Competition & http://www.spu.edu/depts/sbe/svpc.asp & University & Plans & 47 & 47 & 2 & NA & $100 \%$ \\
\hline 18 Social Venture Captial Investment Competition & http://www.svcic.org/ & University & No Response & 0 & NK & NK & NA & NA \\
\hline 19 Stanford's Social E-Challenge & http://bases.stanford.edu & University & Send Email & 0 & 30 & 3 & NA & NA \\
\hline 20 Tufts Entrepreneurship Business Plan Competition & http://gordon.tufts.edu/leadCompetitions.htm & University & Send Email & 0 & NK & NK & NA & NA \\
\hline 21 Tulane Business Plan Competition & http://www.tulanebusinessplancompetition.com/ & University & Not Interested & 0 & NK & NK & NA & NA \\
\hline 22 Social Innovation Competition & http://www.utexas.edu/lbj/rgk/competition/index.php & University & Plans & 133 & 133 & 3 & NA & $100 \%$ \\
\hline 23 University of Michigan - DTE Clean Energy Prize & http://mpowered.studentorgs.umich.edu & University & No Response & 1 & 1 & NK & 0 & NA \\
\hline 24 University of Washington GSEC & http://bschool.washington.edu/gsec & University & Send Email & 4 & 100 & 3 & NA & $4 \%$ \\
\hline 25 William James Foundation Socially Responsible Competition & http://www.williamjamesfoundation.org & Non-Profit & Send Email & 4 & 120 & 4 & NA & $3 \%$ \\
\hline \multirow[t]{2}{*}{26 Yale Entrepreneurial Society (YES) } & http://www.yesatyale.org/ & University & No Response & 0 & NK & $\mathrm{NK}$ & $\mathrm{NA}$ & NA \\
\hline & & & & 254 & 2884 & & 304 & \\
\hline
\end{tabular}

${ }^{*}$ NK $=$ Not Known

*** Six did not respond to emails, Seven give me emaills of past-participants that I contacted directly, Seven sent an email on my behalf, Four only granted me a meeting, \& Two gave me plans

The \# Plans was the estiimated number of plans that have been produced as a result of the competition in question based on information from websites and meetings 
to businesses other than social ventures, or because they were not interested in this research. These non-relevant sponsoring entities did not require a business plan (5 competitions), did not have a social venture track (4 competitions), provided referrals to another entity in their university (2 competitions), did not include social ventures (3 competitions), or were not interested as their organizer was on sabbatical, plans were for their students only, or they were too busy (5 competitions).

Table 3 details the names, eligibility criteria, and year the 26 relevant social venture competitions or tracks were launched. Appendix 4 details the initial email sent to each sponsoring entity. This email inquires if the sponsoring entities are interested in participating in this research by providing the social venture business plans that participated in their competition, or by sending an email to past competition participants to see if they are interested in participating in the research, or by directly providing the emails of their past participants to be contacted directly by the researcher. This introductory email was sent in early December 2008, and three follow-up emails were sent in late January/early February 2009, in late March 2009, and finally in mid April 2009.

Table 4 details the number of plans received from each competition. In most cases sponsors of business plan competitions were not able to provide business plans directly due to confidentiality agreements signed with past-participants. However, two competitions provided all the plans submitted to their competition directly. Seven sponsors of business plan competitions agreed to send out an email to competition past 
participants to gauge their interest in providing their business plan to participate in this research. Sponsoring institutions were provided with the email in Appendix 5 and were allowed to revise it as they saw fit. Unfortunately, only seventeen past participants sent their plans when sponsors contacted past participants directly. Seven competition sponsors provided the contact information of past participants who were then contacted directly with the email in Appendix 6. The response rate improved when past participants were contacted directly as seen in Table 4, and 55 plans were received. Participants had the option to sign the confidentiality agreement seen in Appendix 7. Some social ventures had their own non-disclosure agreement that had to be signed before any business plan document would be provided. Of the remaining business plan competitions, six of these sponsors did not respond to emails and four sponsors participated in a meeting, but later did not follow-up. Appendix 8 details the questions asked in meetings with universities and nonprofits sponsoring the business plan competitions.

Ultimately, 254 business plans were collected from 15 different sponsoring entities. Complete business plans were received from both UT Austin (133 plans) and Seattle Pacific University (47 plans) from competitions held in 2007, 2008, and 2009. Individual plans were collected from past participants from Baruch College, Brigham Young University, California Cleantech Open, Carnegie Mellon, University of Colorado at Boulder, DTE Clean Energy, Florida International University, Gonzaga University, Massachusetts Institute of Technology, New York University, the University of Washington, and the William James Foundation. In addition, the Ashoka Social 
Business Competition in Brazil provided six business plans, but these were not included in the dissertation sample as they represented later stage social ventures and this competition was not based in the United States. The 55 plans representing green technology ventures were also taken out of the sample, since these green-tech ventures had a more economic focus and were operationally more sophisticated and technology centered than most of the social ventures. Both the green-tech ventures (Meyskens \& Carsrud, 2010) and the Ashoka business plans can be analyzed separately in future research. After cleaning the data for duplicates or ventures that participated in multiple years in a competition, 189 business plans remained.

Convenience sample. Drawing the sample from a business plan competition represents a convenience sample, but has several advantages. First, these competitions identify social ventures in the early stages of entrepreneurial activities. Second, analyzing documents or business plans submitted to make funding decisions is a common method to evaluate nascent characteristics by venture capitalists (Kirsch, Goldfarb, \& Gera 2009) and has been used to identify team characteristics (Foo Wong \& Ong, 2005). Thus, evaluating business plans submitted to business plan competitions represents a means to systematically identify and analyze nascent social ventures. Third, given the multifaceted definitions of social ventures, by focusing on social ventures that participated in business plan competitions, the definition of appropriate social ventures is determined by the competition sponsor. Finally, participants in these business plan competitions share similar characteristics in terms of age, education, and professional experience since students generally must participate in the competition. 
Nevertheless, this sample is a convenience sample of social ventures that has limitations. Convenience samples are not necessarily representative of a phenomenon and may contain biases (Krippendorf, 2004: 121). Some of these business plans were originally written as part of a university class or assignment and were never intended to be launched. At the same time, these plans were primarily written by students who generally have less work experience and knowledge on how to run a venture. Finally, each social venture business plan competition defines social ventures slightly differently, which could lead to distinct types of social ventures participating in each competition. Some of these competitions are also more rigorous in their judging criteria and thus some competitions might have more sophisticated or developed plans.

Ideally, the attributes of the studied population should be compared to the characteristics of a representative sample of the general population along observable dimensions. Unfortunately, most social venture support organizations from which comparison samples could be drawn focus on high performing social ventures (Ashoka Foundation, Skoll Forum, Schwab Foundation) or enterprising nonprofits (Social Enterprise Alliance). Nevertheless, the most representative sample of social ventures can be drawn from the United States Global Entrepreneurship Monitor (U.S. GEM) which randomly surveys individuals in the population to identify the rate of entrepreneurial activity.

Social ventures in the U.S. GEM population are examined and it is found that they share similar attributes to this sample as they both include social purpose, nonprofit, and hybrid ventures. Neck, Brush and Allen (2009) use this sample and identify social purpose, 
nonprofit, and hybrid ventures as the three types of social entrepreneurial ventures. Emerson and Bonini (2003) also identify social ventures as for-profit, nonprofit, and hybrid organizations with a primary social purpose.

\section{Measurement techniques}

Content analysis. The collected business plans are analyzed using human and computer aided content analysis. The use of content analysis in organization studies has become more common in the last twenty-five years across management research streams as it enables scholars to both explore qualitative themes and conduct quantitative analysis (Duriau, Reger, \& Pfarrer, 2007). Duriau, Reger, and Pfarrer (2007) identify 98 management studies that used content analysis in the fields of business policy and strategy, cognition, research methods, organizational behavior, human resources, social issues in management, technology management and organizational theory. Content analysis is often used in corporate social responsibility research (Chapple \& Moon, 2005; Chaudhri \& Wang, 2007). In addition content analysis to assess social ventures is increasingly more common. Meyskens, Robb-Post, Stamp, Carsrud, and Reynolds (2010) code the profiles of Ashoka social entrepreneurs. Moss, Short, Payne, and Lumpkin (2010) code the mission statements of social ventures to assess their identities. Whitman (2009) content analyzes the vision and mission statements of forty foundations to better understand their social values. 
Content analysis serves as a means to systematically classify and quantify qualitative material through inferences from text that conform to a set of procedures to ensure validity and reliability (Krippendorf, 2004; Neuendorf, 2003). Coding is the transcribing, recording, categorizing, or interpreting of given units of analysis into a data language to facilitate comparison and analysis (Krippendorf, 2004: 200). As part of this process, coding instructions are developed which detail explicit rules for raters or coders that interpret certain categories or phenomena in textual material. In this study, the author developed a codebook based on a small sub-sample of the larger sample of business plans. Many of the measures developed are dichotomous which assess whether certain characteristics of a social venture are present in a social venture or not.

Exploratory analysis. The author first conducted an exploratory analysis of the Executive Summaries of all the business plans to gain a better understanding of the sample and potential variables of interest. An exploratory analysis of the Executive Summaries of the business plans was conducted in August 2009. This provided greater insight into the type, legal structure, location, and prevalence of partnerships in the social venture sample. In addition the role of partnerships in social ventures was also assessed based on the coding of the business plans Executive Summaries (Meyskens \& Carsrud, 2009). Nonprofit ventures were found to be significantly more likely to stress the importance of partnerships than green-tech and social businesses. In addition, plans from ventures based in Africa, Latin America and Asia significantly demonstrated more prevalence of partnerships than plans from the United States. Social ventures in Africa stressed partnerships the most, followed by Latin America, Asia, and, finally, the United States 
(Meyskens \& Carsrud, 2009). These results were encouraging and provided the basis for a more detailed analysis of partnerships as detailed in this study.

Then, exploratory open coding of 44 of the full green-tech business plans was conducted. A grounded or emergent process of variable identification helped classify key variables under the categories of partnerships, resource conditions, strategies, competitive advantage, and demographic characteristics (Krippendorf, 2004: 99). This open coding led to the development of a codebook. The coding scheme was presented at an academic conference and in follow-up meetings in which academic and practitioner experts in the area provided additional feedback. These comments led to the further revision of the codebook. In addition, this exploratory analysis led to a paper analyzing the role of partnerships in green-tech ventures (Meyskens \& Carsrud, 2010).

This initial codebook was then used to conduct exploratory open coding on 10 full social venture business plans and to train two independent raters. These raters practiced coding this subsample of the larger sample of business plans independently, and then any coding variance was discussed and recoded based on reaching agreement between the independent raters. Then the codebook was revised accordingly. This process repeated itself for several iterations until appropriate inter-rater agreement was achieved as per the Neuendorf methodology $(2003 ; 134)$. Then the raters coded the larger sample of the remaining 179 business plans independently by consistently applying the final revised codebook in Appendix 9 throughout the analysis. As per content analysis methodology, several random checks were conducted to ensure consistent agreement (Krippendorf, 
2004; Neuendorf, 2003) by inputting the coders' results into the online intercoder reliability testing tool ReCal2 (http://dfreelon.org/utils/recalfront/recal2/). In the final check, both raters coded 39 plans and the inter-rater percentage agreement was $89 \%$.

Reliability is the extent to which a measuring procedure yields the same results on repeated trials. The notion relevant to content analysis is that a measure is not valuable if it can be conducted only once or only by one particular person (Neuendorf, 2003: 112). Reliability is achieved by substantial agreement of results among multiple iterations across coders (Krippendorf, 2004: 211-215). Validity is the extent to which a measuring procedure represents the intended and only the intended concept (Neuendorf, 2003: 112). Thus, a measuring instrument is valid if it assesses what the user claims it measures.

Survey instrument. A survey instrument is used to follow-up with the individuals that participated in the business plan competition. The survey instrument includes questions that are similar to those coded through the content analysis of the business plans. These questions track the actual achievement of different venture development activities, the creation of social, economic, and environmental value, intent to launch, actual launch, and amount won through the business plan competition. Initially an exploratory survey was developed and sent to 50 business plan competition participants who did not provide their business plans for this research. These individuals were comparable to the past participants for which business plans were received and analyzed. In addition, the feedback of experts, academics and social venture practitioners was incorporated into the final survey. 
The final survey seen in Appendix 10 was approved by the Institutional Review Board in March 2010 (Appendix 3) and implemented using the online tool Survey Monkey. Individual emails were sent to the primary contact of the team who participated in the business plan competition asking them to participate in the survey (Appendix 11). If the primary contact email did not work, the secondary contact was emailed. In the case of Seattle Pacific University, all contacts for each business plan were emailed as this is the data that the university provided. The original email was followed by three follow-ups sent in one-week intervals during March and April 2010.

\section{Figure 2: Survey respondents}

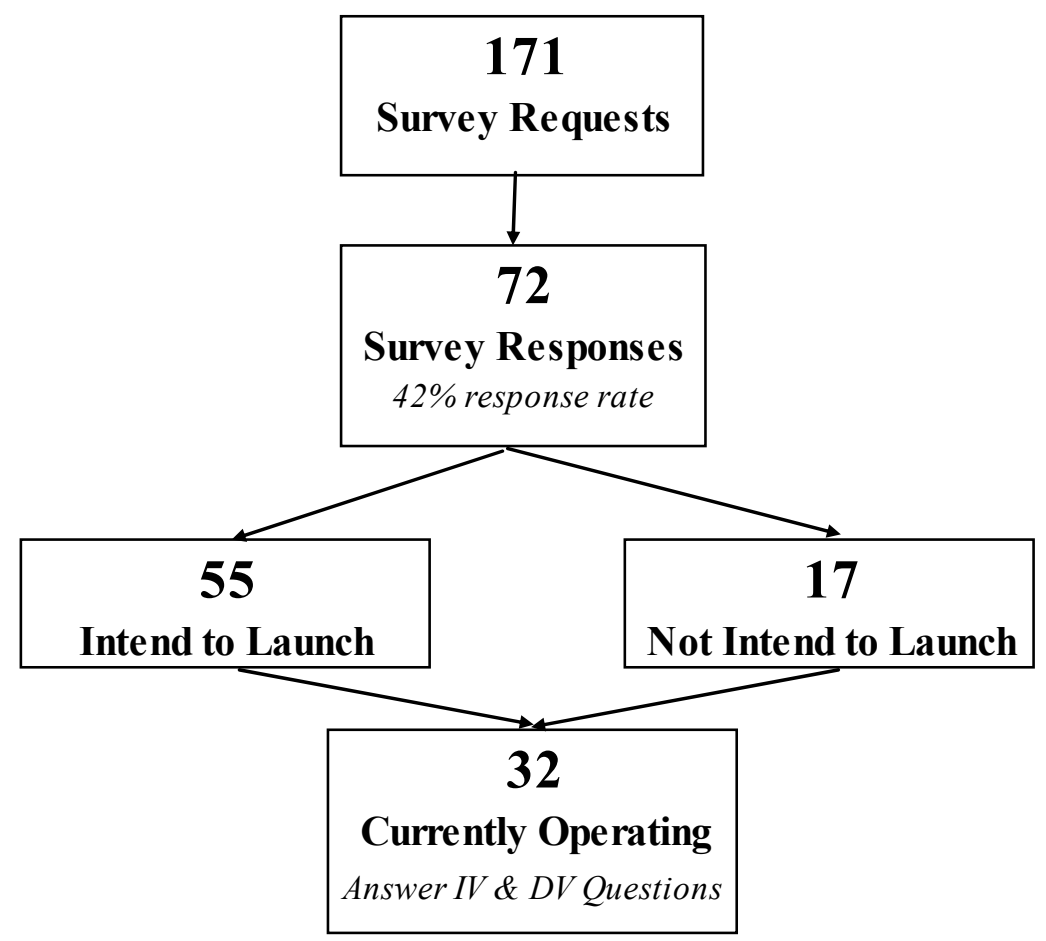

The breakdown of the survey respondents is detailed in Figure 2. Overall 275 individuals representing 179 social venture business plans were contacted, but emails for only eight 
teams were not operational. Of the 171 valid survey requests, responses were received for 72 social ventures, representing a $42 \%$ response rate. This response rate is above average for surveys and provided initial insight into the current status of the social ventures that participated in the business plan competition. Nevertheless, according to the survey, only 55 of these 72 individuals that participated in the business plan competition actually intended to launch the venture. Only 32 survey respondents that were operating or in the process of operating answered the partnership, resource conditions and competitive advantage questions. Thus the survey is primarily exploratory and is used as a means to assess the relationship between partnership diversity, resources, and strategies in the business plan with likelihood of the social venture to launch (as assessed in the survey).

\section{Variables}

The content analysis software NVivo facilitated the coding of binary variables within the focused categories of competitive advantage, partnerships, strategy, resource conditions, and demographic characteristics as detailed below and in Tables 5, 6, and 7. The categories discussed reflect academic or technical definitions of social ventures as well as

inductive and grounded operationalizations, emerging from the business plans. Using the business plans and content analysis, each binary variable is coded a " 1 " if it is present in the business plan and otherwise it is coded as a " 0 ". 
Dependent variables. The study uses two subjective measures of nascent social venture competitive advantage: value creation and venture development as seen in Table 5. Subjective performance measures are fairly common in entrepreneurship research since researchers have different definitions of entrepreneurial success depending on the industry or stage of the venture (Gruber, 2007). Since the primary purpose of social ventures is to create social value and benefit society, the potential for value creation is an important goal and means to achieve a competitive advantage. At the same time, as these are nascent social ventures, in order for the social venture to achieve their value creation goals, they must show signs or activities that represent venture development. The follow-up survey also measures competitive advantage by assessing the actual achievement of venture development activities, value created, and whether the venture launched.

Value creation. Measuring outcomes is extremely important for social ventures and often consists of assessing different levels of economic, social, and environmental value creation. Distinct quantitative (Emerson, 1999) and qualitative (Elkington, 2001; Kaplan, 2002; Zadek, 1998) dimensions and criteria measure social value. However tracking social value is time consuming and costly as it is not standardized (Clark et al., 2004; Emerson \& Bonini, 2003). In addition, identifying adequate measures that represent social and environmental performance benchmarks that discern causal relationships is difficult. The triple bottom line is the most simple qualitative social metric (Nicholls, 2005) which measures financial performance as well as social and environmental outcomes (Elkington, 1997, 2001). However, the social and environmental outcomes are 
typically descriptive, rather than quantitative, which makes it difficult to compare these social outcomes across ventures. The Balanced Scorecard is another common qualitative comparison tool used by nonprofit organizations (Kaplan, 2002; Kaplan \& Norton, 1996). The approach provides a clear framework for defining a causal link between nonfinancial performance measures and the achievement of mission. The only rigorously quantitative model of social impact measurement is the Social Return on Investment (SROI) framework which measures value, investment and return (Emerson, 1999, 2003).

This study builds off these different methods, and assesses the potential for value creation as discussed in the business plan. The business plans are coded as to whether different aspects of economic, social, and environmental value are mentioned in the business plan. Value creation represents the social, economic, and environmental value potential of the venture. For example each business plan is assessed as to whether it emphasizes the ventures potential for social value by improving community development, education, health, quality of life, quality of water, or detailing responsible business practices and social return on investment. Then each social venture is given a social value which indicates the percentage of these eight variables that are emphasized or mentioned in the business plan. For example, one social venture Proximity brings groups from the United States to implement service projects in Central America. These projects impact local communities (community development), provide medical services (health), and provide literary training (education). The SROI for Proximity is calculated by adding together the projected donations and service hours. Thus this social venture shows evidence of four 
types of social value in their business plan and is given a social value score of 50\% (four out of eight).

These variables are also created for economic and environmental value as seen in Table 5. Economic value accrues to employees as jobs and educational incentives and to clients or beneficiaries in money saved or earned through participation in the venture or integration into the supply chain, or through increases in productivity or training to improve knowledge in an area. In addition, some social ventures also donate a percentage of profits to social causes or emphasize their economic return on investment. For example, the social venture Proximity, mentioned above donates $20 \%$ of their profits to nonprofit institutions, creates employment and trains individuals at the local level. Thus the Proximity business plan shows evidence of three types of economic value creation and has an economic value score of $38 \%$ (three out of eight).

Environmental value includes benefits for the environment through recyclable products, eco-friendly products/services or policies that promote recycling, energy savings, and reduction in greenhouse gas emissions. The value creation variable is the average of the sum of the economic, social, and environmental value variables. For example, another social venture in the sample offers carbon neutral shipping and proposes to create environmental value by reducing greenhouse gas and general environmental value through environmentally responsible business practices in ecommerce. Thus this social venture has an environmental value of $40 \%$ (two out of five). 
Table 5: Dependent variables

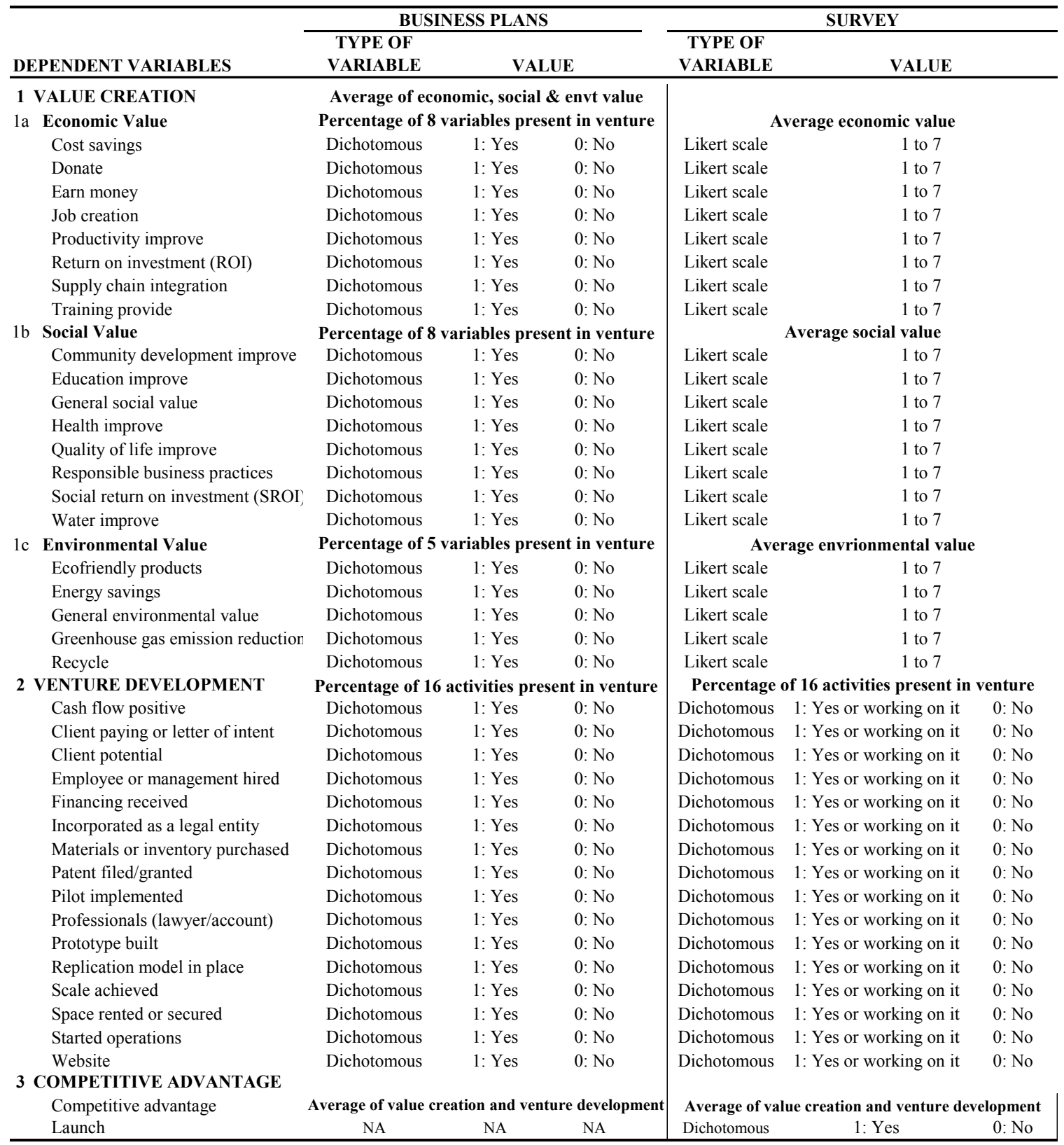

Similar variables are created from the survey sample. Respondents ranked their responses on a seven-point Likert scale where 7 is strongly agree and 1 is strongly disagree. The question asks, "To what extent do you agree that the social venture is 
creating value now or plans to create value in the future by...impacting community development, improving education, etc." for each of the different types of social, economic and environmental value measures. Corresponding average social, economic, and environmental value variables are created which measure the average Likert score for each of the categories. In addition survey respondents are asked to assess their overall satisfaction with the level of social, environmental, and economic value created on a seven point Likert scale. Two survey value creation variables are created. One measures the average social, economic, and environmental value created from the first set of value variables. The other measures the average satisfaction with the social, economic, and environmental value created.

Venture development. New ventures do not emerge suddenly or spontaneously, but require a great many activities that represent development (Reynolds \& Curtin, 2008). These activities establish the physical structure and organizational processes of a new firm (Bhave, 1994; Delmar \& Shane, 2003). The business plans are coded as to whether they show evidence of the existence or process of developing sixteen different venture development activities provided in Table 5 including a positive cash flow, a paying client, a potential client, an employee hired, management hired, financing received, incorporation as a legal entity, materials or inventory purchased, patent filed or granted, professionals hired, a prototype built, a replication model in place, scale achieved, space rented, started operations, or built a website. The venture development variable is a percentage of the total number of sixteen activities achieved as indicated in the business plan. So if a social venture shows evidence of having received financing, incorporating 
as a legal entity, filing a patent, identifying a potential client, starting operations, and building a website, the venture development variable is $38 \%$ or six out of sixteen venture development activities have been achieved.

Venture development is also assessed in the follow-up survey. Respondents are asked to indicate whether each of the activities in Table 5 has been achieved or are in progress. The venture development variable from the survey assesses the average percentage of venture development activities that has actually been achieved.

Launch is assessed through the follow-up survey. Survey respondents are asked whether the social venture actually launched (started or initiated operations). A social venture that is able to launch is likely to create more value as it can gain more credibility and have access to additional resources. Launching is an important phase in the development of a venture and it is considered a competitive advantage variable in this study.

Competitive advantage. The general competitive advantage of a social venture is assessed through the value creation and venture development variables. Competitive advantage is the average of the value creation and venture development variables and is assessed for both the business plan and survey samples. For example, if a venture has a value creation percentage of $30 \%$ and a venture development percentage of $50 \%$, then the competitive advantage percentage is $40 \%$. Thus competitive advantage is measured as the mean of value creation and venture development. 


\section{Table 6: Independent variables}

\begin{tabular}{|c|c|c|c|c|c|c|}
\hline \multirow[b]{2}{*}{ INDEPENDENT VARIABLES } & \multicolumn{3}{|c|}{ BUSINESS PLANS } & \multicolumn{3}{|c|}{ SURVEY } \\
\hline & TYPE OF VARIABLE & \multicolumn{2}{|c|}{ VALUE } & $\begin{array}{c}\text { TYPE OF } \\
\text { VARIABLE } \\
\end{array}$ & \multicolumn{2}{|c|}{ VALUE } \\
\hline \multicolumn{7}{|l|}{1 PARTNERSHIPS } \\
\hline 1a Partnership Importance & Dichotomous & 1: Yes & $0:$ No & Likert scale & & \\
\hline 1b Partnership diversity & \multicolumn{3}{|c|}{ Percentage of 9 partnerships in venture } & \multicolumn{3}{|c|}{ Total number of 9 different partnerships } \\
\hline Community & Dichotomous & 1: Yes & $0:$ No & Likert scale & \multicolumn{2}{|c|}{1 to 7} \\
\hline Corporations & Dichotomous & 1: Yes & $0:$ No & Likert scale & \multicolumn{2}{|c|}{1 to 7} \\
\hline Government & Dichotomous & 1: Yes & $0:$ No & Likert scale & \multicolumn{2}{|c|}{1 to 7} \\
\hline Financial Institutions & Dichotomous & 1: Yes & $0:$ No & Likert scale & \multicolumn{2}{|c|}{1 to 7} \\
\hline Individuals & Dichotomous & 1: Yes & $0:$ No & Likert scale & \multicolumn{2}{|c|}{1 to 7} \\
\hline Religious & Dichotomous & 1: Yes & $0:$ No & Likert scale & \multicolumn{2}{|c|}{1 to 7} \\
\hline Social ventures & Dichotomous & 1: Yes & $0:$ No & Likert scale & \multicolumn{2}{|c|}{1 to 7} \\
\hline Schools & Dichotomous & 1: Yes & $0:$ No & Likert scale & \multicolumn{2}{|c|}{1 to 7} \\
\hline Universities & Dichotomous & 1: Yes & 0: No & Likert scale & \multicolumn{2}{|c|}{1 to 7} \\
\hline 1c Private sector partners & \multicolumn{3}{|c|}{ Percent of corps \& financial inst in venture } & \multicolumn{3}{|c|}{ Avg Likert score for corps \& fin inst } \\
\hline 1d Public sector partners & \multicolumn{3}{|c|}{ Percent of govt, school \& uni in venture } & \multicolumn{3}{|c|}{ Avg Likert score for govt, school, \& uni } \\
\hline 1e Social sector partners & Percent of commty, in & s, relg, & venture & Avg Likert score & emmty, & s, rel,sv \\
\hline 2 STRATEGY & & & & & & \\
\hline 2a Social innovation & Percent of 3 innovatio & dimensic & venture & Avg Likert scor & $r$ tech \& & t dim \\
\hline Technology dimension & Dichotomous & 1: Yes & $0:$ No & Likert scale & & \\
\hline Market dimension & Dichotomous & 1: Yes & $0:$ No & Likert scale & & \\
\hline Strategy dimension & Dichotomous & 1: Yes & $0:$ No & NA & NA & NA \\
\hline 2b Earned Income & & & & & & \\
\hline Earned income streams & Number of earn & income & & Sat - Likert scale & & \\
\hline EI importance & Earned income meas & ed on a & nt scale & Earned income me & red on a & oint scale \\
\hline 3 RESOURCE CONDITIONS & & & & & & \\
\hline 3a Human Capital & Percentage of 5 huma & capital $v$ & venture & Dichotomous & 1: Yes & $0:$ No \\
\hline Advice \& support & Dichotomous & 1: Yes & $0:$ No & NA & NA & NA \\
\hline Design \& development & Dichotomous & 1: Yes & $0:$ No & NA & NA & NA \\
\hline Human capital & Dichotomous & 1: Yes & $0:$ No & NA & NA & NA \\
\hline Knowledge & Dichotomous & 1: Yes & $0:$ No & NA & NA & NA \\
\hline Volunteers & Dichotomous & 1: Yes & $0:$ No & NA & NA & NA \\
\hline 3b Physical Capital & Percentage of 5 physic & capital & venture & Dichotomous & 1: Yes & $0:$ No \\
\hline Input & Dichotomous & 1: Yes & $0:$ No & NA & NA & NA \\
\hline Materials & Dichotomous & 1: Yes & $0:$ No & NA & NA & NA \\
\hline Patent or license access & Dichotomous & 1: Yes & $0:$ No & NA & NA & NA \\
\hline Product testing & Dichotomous & 1: Yes & $0:$ No & NA & NA & NA \\
\hline Space & Dichotomous & 1: Yes & $0:$ No & NA & NA & NA \\
\hline 3c Financial Capital & Percentage of 4 financ & capital & n venture & Dichotomous & 1: Yes & $0:$ No \\
\hline Donations & Dichotomous & 1: Yes & 0: No & NA & NA & NA \\
\hline Grants & Dichotomous & 1: Yes & $0:$ No & NA & NA & NA \\
\hline Investments & Dichotomous & 1: Yes & $0:$ No & NA & NA & NA \\
\hline Monetary general & Dichotomous & 1: Yes & 0 : No & NA & NA & NA \\
\hline 3d Social Capital & Percentage of 4 socia & apital ve & venture & Dichotomous & 1: Yes & $0:$ No \\
\hline Access & Dichotomous & 1: Yes & $0:$ No & NA & NA & NA \\
\hline Distribution & Dichotomous & 1: Yes & $0:$ No & NA & NA & NA \\
\hline Endorsement & Dichotomous & 1: Yes & $0:$ No & NA & NA & NA \\
\hline Marketing & Dichotomous & 1: Yes & $0:$ No & NA & NA & NA \\
\hline 4 Heterogeneous resource conditions & Percent of differe & types of & irces & Total number of ca & resourc & n venture \\
\hline
\end{tabular}

Independent variables. The independent variables include partnerships, social venture strategy, and resource conditions as seen in Table 6. These variables are measured both through the content analysis of the business plans and through the follow-up survey. 
Only 32 of the ventures that are currently operating or in the process of being developed responded to these questions in the survey, thus these results are merely exploratory.

Partnerships. Partnership variables include partnership importance, partnership diversity, private sector partners, public sector partners, and social sector partners. In the content analysis of the business plans, partnership importance to the venture is coded by assessing whether partnerships are mentioned in the Executive Summary of the business plan as important to the achievement of the social mission. The presence of partnerships in the Executive Summary, a central component of the business plan, suggests the importance of partnerships to the social venture overall. Meyskens and Carsrud (2009) examine the partnership importance to the venture using the Executive Summary in the exploratory analysis for this dissertation. The use of a dichotomous variable to represent the importance of a phenomenon is common in organizational research. For example, a dichotomous variable might represent the importance of corporate social responsibility to a company if present in annual reports or on a website (Chapple \& Moon, 2005; Chaudhri \& Wang, 2007). In the survey data, partnership importance is assessed through the following question, "To what extent are partnerships important to the achievement of your social venture's goals?" Survey participants are asked to answer this question on a seven point Likert Scale with seven equal to strongly agree and one equal to strongly disagree.

Partnership diversity represents the overall variety in types of partners with which the social venture engages and exchanges resources. The types of partners include 
community, corporations, government entities, religious organizations, financial institutions, individuals, social ventures, schools, and universities. These types of partners are identified in the business plan and coded separately as individual binary variables according to whether these types of partners are important to venture strategy. The partnership diversity variable is the percentage of these nine types of partnerships that are present in a social venture. Since business plans generally do not state the total number of partners the variable partnership diversity provides a means to assess the importance of many types of partners. For example, if the business plan mentions partnerships with corporations, government entities, religious organizations and other social ventures, the partnership diversity score is $44 \%$ (four out of nine). The social venture Proximity proposes to partner with travel agencies (corporations) providing service trips to "establish industry best practices and share ideas", rather than compete for volunteers. They also mention the "opportunity to partner with an NGO (social venture) that works next to the city dump providing meals and activities for the needy children that live there." Finally the Proximity business plan says that "in Guatemala the partner organization is a private school (school) in a high-poverty area of the city". Thus Proximity mentions partnerships with corporations, social ventures, and schools and has partnership diversity of $33 \%$ (three out of nine).

In the survey data, each of the individual types of partnerships is ranked according to their importance on a seven-point Likert Scale. Those types of partnerships that are coded 6 or 7 (strongly or moderately agree that the type of partnership is important) are used to create a new type of dichotomous partnership variable for each type of 
partnership. Partnership diversity in the survey data is a sum of the created dichotomous variables which represent the importance of different types of individual partnerships.

Partnerships with the public, private, and social sector are also assessed for their presence in the business plans. Private sector partners is the percentage of the distinct types of private sector partners in the business plan including corporations and financial institutions that are important to a social venture. Public sector partners is the percentage of the different types of public sector partners including government entities, schools, and universities that are important to a social venture. Thus if a social venture business plan only mentions partnerships with government entities, but not with universities or schools, the public sector score is 33\%. Social sector partners is the percentage of the distinct types of social sector partners in the business plan including community, individuals, religious entities, and social ventures that are important to the venture. Thus if a social venture mentions partnerships with religious entities and other social ventures, but not with the community or individuals, the social sector partner score is $50 \%$.

In the survey, private sector partners is the average Likert score of the importance of corporate and financial sector partners, public sector partners is the average Likert score of the importance of government, schools and university partners, while social sector partners is the average Likert score of the importance of community, individual, social venture, and religious entity partners. 
Other studies use similar methods to assess partnerships. Meyskens, Robb-Post, Stamp, Carsrud, and Reynolds (2010) create a similar sum variable to assess the prevalence of different types of partnerships in social ventures. They find significant relationships between greater partnership diversity and financial capital and innovativeness. Guo and Acar (2005) measure the diversity of government funding streams through a categorical variable that indicates the absence of any government funding stream, the presence of one to two government funding streams, and the existence of three or more government funding streams. Gulati and Higgins (2003) measure the number of prominent strategic alliances to assess partnerships.

Social venture strategy. Using the business plan sample, two types of social venture strategies are assessed: social innovation and earned income. Social innovation is the percentage of the three dichotomous variables that combine a technology, market, and strategy dimension of a social venture. Technology measures whether a social venture uses technology as a key component of strategy and market measures whether a social venture service or product is new to the market. The strategy dimension assesses whether the venture uses a new type of business model or strategy. Gruber (2007) uses a similar methodology to measure innovation, by adding the linear sum of the two component scores and dividing it by two. For example, one social venture proposes to introduce and sell bicycle driven carts to haul goods in Haiti. These carts seek to replace the carts that sometimes weigh up to 500 pounds that are pulled solely by humans. Thus the new product will be new to the market, will introduce a new technology innovation (as stated in the business plan), and proposes to implement the bicycles through a new 
strategy or business model (microlending program). Thus this social venture implements all three components of social innovation and has a social innovation score of $100 \%$ (three out of three).

In the survey data, social innovation is measured by assessing the average innovation of the two variables technology and market innovation. Each of these variables is assessed on a 7 point Likert scale where seven is strongly agree and one is strongly disagree. Survey respondents are asked to answer the questions: The social venture offers a service or product that has not been offered by competitors in nearby geographic areas and the social ventures uses a new technology or technology in a new way to reach the target population.

Social venture earned income assesses the primary products or services being offered for which revenue is earned. Using the business plans, earned income is measured using two variables. First, earned income streams assesses the total number of different types of services or products being offered by a social venture for which it earns revenue. For example, a social venture might earn income from selling handicrafts on a website as well as advertising on that website. The social venture Proximity only earns income by selling the all-inclusive service oriented trip to Guatemala. Earned income importance is measured on a five point Likert scale as coded by the independent raters of the business plans. Five indicates earned income is very important as there are no other sources of revenue besides earned income. Four suggests earned income is important as it is one of 
the top revenue streams. Three suggests that earned income is somewhat important as only one of multiple types of revenue streams. Two suggests that earned income is not important as it will not be pursued in the short term. One indicates that the venture has no plans to have an earned income strategy in the near or long term.

In the survey data, earned income importance is measured using the question How important is your earned income strategy to the social venture? This question is answered on a five-point scale where five is very important. Earned income is the only source of revenue; four is important. Earned income is one of the top revenue streams; Three is somewhat important. Earned income is only one of multiple types of revenue; Two is not at all important. Earned income will be pursued in a few years; and one is not relevant as no earned income strategy or plans to have one. Earned income satisfaction is measured on a seven point Likert scale answering the question, I am satisfied with the level of earned income achieved, where seven is strongly agree and one is strongly disagree.

Resource conditions. In the business plans, variables which represent the resource conditions include financial capital, physical capital, human capital, social capital, and heterogeneous resource conditions. Separate variables are coded which represent different human, physical, financial, and social capital resources that are mobilized through partnerships. Each capital variable is a percentage of the individual resources that are present in that capital variable. Human capital includes the binary variables advice/support, human support, knowledge, product design \& development, and 
volunteers. Each of these is coded as a separate binary variable and then the total is summed and divided by five. This variable is multiplied by 100 to indicate the percentage of human capital present in a particular venture. For example, the social venture Proximity mentions how they gain knowledge and "share ideas" or get advice from corporate partners or travel agencies that offer similar services. Thus two of the types of human capital resources are gained through partnerships and Proximity has a human capital score of $40 \%$ (two out of five).

Physical capital includes inputs, materials, patent/license product testing, and space. Each of these is coded as a separate binary variable and then the total is summed and divided by five. This variable is multiplied by 100 to indicate the percentage of physical capital present in a particular venture. These inputs include equipment, computers, or materials important to social venture operations. The space indicates the donation or availability of physical space given to social ventures by their partners so that they can run their programs, services or operations. Financial capital includes donations, grants, investments, and general monetary support. Each of these is coded as a separate binary variable and then the total is summed and divided by four. This variable is multiplied by 100 to indicate the percentage of financial capital present in a particular venture.

Social capital includes access to a target population or market, assistance with distribution and sales, facilitation of marketing or advertising, and general endorsement. Each of these is coded as a separate binary variable and then the total is summed and divided by four. This variable is multiplied by 100 to indicate the percentage of social 
capital present in a particular venture. For example, Proximity gains access to the local population through the local NGOs (social ventures) and schools that they partner with in Guatemala and has a social capital score of $25 \%$ (one out of four).

Heterogeneous resource conditions is the diversity of the resources obtained through partnership and it is calculated as the average of the human capital, physical capital, financial capital, and social capital variables. Galaskiewicz, Bielefeld, and Dowell (2006) also use dichotomous variables to asses the information and support resources gained between organizations. In addition, they also use access, marketing, endorsement, distribution variables to represent social capital.

In order to develop resource condition variables from the survey data, survey participants are asked to respond to the question, What are the most important resources (top three) your social venture gains through partnerships? Based on this question variables are created which represent the human, physical, financial, and social capital gained through partnerships. Human capital is a dichotomous variable where one suggests the presence of at least one type of human capital i.e. knowledge, volunteers, or human capital. Financial capital is a dichotomous variable where one represents the presence of at least one type of financial capital i.e. monetary, financial, or cost reduction. Physical capital is a dichotomous variable where one suggests the presence of at least one type of physical capital, i.e., input, test product, or space. Social capital is a dichotomous variable where one represents the presence of at least one type of social capital i.e. access, feasibility, endorsement, political will, general marketing, advertising, or networking. 
Heterogeneous resource conditions is a sum of these different types of capital gained through partnerships.

Control variables. The control variables are assessed through the business plan sample as seen in Table 7 and include social venture type, venture size, impact, geographic area of clients or beneficiaries, founder start-up experience, business plan competition year, business plan competition sponsor, and business plan completeness. Demographic characteristics are also obtained in the survey, but given the low sample size they are not used as control variables in the analysis.

Table 7: Control variables and demographic characteristics

\begin{tabular}{|c|c|c|c|}
\hline VARIABLES & TYPE OF VARIABLE & \multicolumn{2}{|c|}{ VALUE } \\
\hline \multicolumn{4}{|l|}{ CONTROL VARIABLES - BUSINESS PLANS } \\
\hline 1 Social venture type & \multicolumn{3}{|c|}{ Nonprofit, forprofit or hybrid } \\
\hline 2 Venture size & \multicolumn{3}{|c|}{ Revenue in year 1} \\
\hline 3 Impact (primary area of venture impact) & \multicolumn{3}{|c|}{ Poverty alleviation, education, envt, health, nonprofit } \\
\hline 4 Geographic area of clients or beneficiaries & \multicolumn{3}{|c|}{ Africa, Asia, Global, Latin America, United States } \\
\hline 5 Founder start-up experience & \multicolumn{3}{|c|}{ Number of previous ventures started } \\
\hline 6 Business plan competition participation year & \multicolumn{3}{|c|}{ 2004, 2005, 2007, 2008 \& 2009} \\
\hline 7 Business plan competition sponsor & \multicolumn{3}{|c|}{ Baruch, BYU, FIU, Gonzaga, MIT, SPU, UTAustin, Wash, WJF } \\
\hline 8 Business plan completeness & \multicolumn{3}{|c|}{ Sum of 7 variables below } \\
\hline Balance sheet & Dichotomous & 1: Yes & $0:$ No \\
\hline Cash flow projections & Dichotomous & 1: Yes & $0:$ No \\
\hline Financial written section & Dichotomous & 1: Yes & 0 : No \\
\hline Income statement projections & Dichotomous & 1: Yes & $0:$ No \\
\hline Management section & Dichotomous & 1: Yes & $0:$ No \\
\hline Marketing/strategy section & Dichotomous & 1: Yes & $0:$ No \\
\hline Social impact section & Dichotomous & 1: Yes & $0:$ No \\
\hline \multicolumn{4}{|l|}{ DEMOGRAPHIC CHARACTERISTICS- SURVEY } \\
\hline 1 Social venture type & \multicolumn{3}{|c|}{ Nonprofit, forprofit or hybrid } \\
\hline 2 Business plan competitions - \# participated in & \multicolumn{3}{|c|}{$1,2,3,4$ or 5 or more } \\
\hline 3 Business plan competition - amount win & \multicolumn{3}{|c|}{$0, \$ 1-\$ 4,999, \$ 5,000-\$ 9,999, \$ 10,000-\$ 14,999, \$ 15,000+$} \\
\hline 4 Highest completed degree & \multicolumn{3}{|c|}{ High school, undergraduate, masters, $\mathrm{PhD}$} \\
\hline 5 Work experience & \multicolumn{3}{|c|}{ None, $1-4$ yrs, 5-9 yrs, $10-20$ yrs, 21 yrs +} \\
\hline 6 Gender & \multicolumn{3}{|c|}{ Male or female } \\
\hline 7 Race & \multicolumn{3}{|c|}{ Caucasian, Hispanic, Asian, Other } \\
\hline
\end{tabular}


Social venture type includes nonprofit entities, for-profit social purpose business, and hybrid ventures. The hybrid ventures contain both for-profit and nonprofit components. The venture size is measured by revenue in year one which is detailed in the business plan in United States dollars. However, since many of these nascent ventures have not yet achieved any revenue, revenue is not the most appropriate measure of firm size. Nevertheless, revenue in year one provides an estimate of the expected (although sometimes inflated) size of the venture. The focus of the venture relates to the primary area of impact of the venture and includes poverty alleviation, health, environment, education, and the nonprofit sector in general. The geographic area of clients or beneficiaries is the primary region in which the business plan proposes or has operations at the time the business plan is written. This includes Africa, Asia, Latin America, United States and a global geographic focus. Founder start-up experience represents the number of previous ventures or organizations the founders have launched or started. The business plan competition year of participation is the year in which the social venture participated in the business plan competition and includes 2004, 2005, 2007, 2008, and 2009. For the business plans that participated in multiple years, the business plan from the most recent year is analyzed.

Business plan completeness is measured to assess the plan's structural conformity and sophistication by evaluating whether the plan includes a marketing section, a management section, a social impact section, financial projections, and tables (cash flow, income statement, and balance sheet) in the business plan. The presence of each of these sections in the business plan is measured as a dichotomous variable and then these 
individual variables are summed to represent business plan completeness. Kirsch, Goldfarb, and Gera (2009) used a similar variable to measure plan completeness, but they assessed eight elements in the business plan.

The survey instrument also assesses demographic characteristics that could be used in future research. However, given the low sample size of the survey data these demographic variables are not used in the analysis. Social venture type measures the nonprofit, for-profit, or hybrid legal structure of the venture. Two variables assess different aspects of the business plan competition. Business plan competition \# assesses the number of business plan competitions in which social ventures participated ranging from one to five or more. Business plan competition amount win assesses the amount of money that individuals won in the business plan competition ranging from nothing to $\$ 15,000$ or more.

Some general demographic characteristics of survey respondents are also assessed. Highest completed degree assesses whether the survey respondent completed high school, undergraduate education, a master's program, or a doctorate. Work experience measures whether the survey respondent has none, 1-4 years, 5-9 years 10-20 years, or 21 years or more work experience. Finally, gender measures whether the survey respondent is male or female, and race assesses whether the survey respondent is Caucasian, Hispanic, Asian, or Other. 


\section{CHAPTER 5: RESULTS}

In order to analyze the data, first the descriptive statistics for the dependent, independent, and control variables are assessed. A primary emphasis is placed on the business plan sample, but the exploratory follow-up survey sample provides some additional insight. Then the hypotheses are assessed using correlations, t-tests, ANOVA, regressions, and non-parametric statistics. Some of the results combine the business plan and survey data to examine how the partnership, resource conditions, and strategy variables in the business plans are related to the ventures that actually launched.

\section{Descriptive statistics}

Dependent variables. Table 8 details the descriptive statistics of the dependent variables and their components based on the business plan sample. The primary dependent variable competitive advantage is an average of value creation and venture development. Each secondary dependent variable is comprised of different components as discussed in the Methodology Chapter in the variables section and in Table 5.

Value creation is an average of economic value, social value, and environmental value. The Executive Summary or Social Impact sections of the business plan refer to the benefits the social venture provides in these three areas. The economic value variables most prevalent in the business plans include earn money (40\%), donations (28\%), and job creation (26\%). Earn money suggests that social ventures assist their clients or 
beneficiaries in increasing their income. Donations includes social ventures that donate a percentage of their profits to social causes. Finally, job creation indicates that the social venture directly details one of their benefits to society as the creation of employment for clients or beneficiaries of their social mission. The social value variable most frequent in the business plans includes improvements in education (50\%), health (41\%), and community development (35\%). The environmental value variable most prevalent in the business plans includes general environmental value (19\%), eco-friendly products $(15 \%)$, and greenhouse gas emission reduction (10\%). Overall, social value is the most prevalent type of value created by the social ventures, as $23 \%$ of the different types of social value are seen in each venture, followed by $19 \%$ of the different types of economic value, and $12 \%$ of the distinct types of environmental value.

Venture development identifies activities that have already been completed as indicated in the business plan. These activities represent different steps that facilitate the development of the social venture. The most prevalent venture development activity includes client potential (41\% of ventures), website (24\%), started operations (21\%), and prototype built (19\%). Client potential indicates the identification of a client through a survey, or actual meetings or interaction with the client. Website suggests that the social venture has already constructed or is in the process of building a website. Started operations indicates that the venture is already operating. Finally, prototype built implies that the social venture is in the process of building or has already constructed a prototype. Both value creation and venture development contribute to the overall competitive advantage 
Table 8: Dependent variables - Business plans

\begin{tabular}{|c|c|c|c|c|c|c|c|}
\hline & Number $^{1}$ & Percent $^{2}$ & Percentavg $^{3}$ & & Number $^{1}$ & Percent $^{2}$ & Percentavg $^{3}$ \\
\hline Value creation* & & & $18 \%$ & Venture development & & & $13 \%$ \\
\hline Economic value & & & $19 \%$ & Cash flow positive & 4 & $2 \%$ & \\
\hline Cost savings & 36 & $20 \%$ & & Client paying or letter of intent & 23 & $13 \%$ & \\
\hline Donate & 50 & $28 \%$ & & Client potential & 74 & $41 \%$ & \\
\hline Earn money & 71 & $40 \%$ & & Employee or management hired & 19 & $11 \%$ & \\
\hline Job creation & 46 & $26 \%$ & & Financing Received & 33 & $18 \%$ & \\
\hline Productivity improve & 18 & $10 \%$ & & Incorporated as a legal entity & 28 & $16 \%$ & \\
\hline Return on investment (ROI) & 16 & $9 \%$ & & Materials or inventory purchased & 4 & $2 \%$ & \\
\hline Supply chain integration & 6 & $3 \%$ & & Patent filed/granted & 6 & $3 \%$ & \\
\hline Training provide & 36 & $20 \%$ & & Pilot implemented & 27 & $15 \%$ & \\
\hline Social value & & & $23 \%$ & Professionals (lawyer/account) & 13 & $7 \%$ & \\
\hline Community development improve & 63 & $35 \%$ & & Prototype built & 34 & $19 \%$ & \\
\hline Education improve & 90 & $50 \%$ & & Replication model in place & 3 & $2 \%$ & \\
\hline General & 12 & $7 \%$ & & Scale achieved & 9 & $5 \%$ & \\
\hline Health improve & 74 & $41 \%$ & & Space rented or secured & 8 & $4 \%$ & \\
\hline Quality of life improve & 39 & $22 \%$ & & Started operations & 37 & $21 \%$ & \\
\hline Responsible business practices & 12 & $7 \%$ & & Website & 43 & $24 \%$ & \\
\hline Social return on investment (SROI) & 34 & $19 \%$ & & & & & \\
\hline Water improve & 8 & $4 \%$ & & & & & \\
\hline Environmental value & & & $12 \%$ & Competitive advantage $* *$ & & & $15 \%$ \\
\hline Ecofriendly products & 26 & $15 \%$ & & & & & \\
\hline Energy savings & 14 & $8 \%$ & & & & & \\
\hline General & 34 & $19 \%$ & & & & & \\
\hline Greenhouse gas emission reduction & 18 & $10 \%$ & & & & & \\
\hline Recycle & 16 & $9 \%$ & & & & & \\
\hline \multicolumn{8}{|l|}{$\overline{n=179}$} \\
\hline * Value creation is $33 \%$ economic value , $33 \%$ env & ironmental vo & ue \& $33 \%$ so & ial value & & & & \\
\hline ** Competitive advantage is $50 \%$ value creation $\&$ & $50 \%$ venture & development & & & & & \\
\hline${ }^{1}$ Number is the number of business plans in which & the variable $\mathrm{i}$ & present; ${ }^{2} \mathrm{Per}$ & ent is the percent & business plans out of $n=179$ in which the variab & resent & & \\
\hline
\end{tabular}


Table 9: Dependent variables - Survey instrument

\begin{tabular}{|c|c|c|c|c|c|c|}
\hline & Average $^{1}$ & Satisfaction $^{2}$ & & Number $^{3}$ & Percent $^{4}$ & PercentAvg $^{5}$ \\
\hline 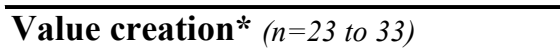 & 5.5 & 5.4 & Venture development ( $n=33$ to 36 ) & & & $67 \%$ \\
\hline Economic value & 5.5 & 5.5 & Bank account open & 26 & $72 \%$ & \\
\hline Cost savings & 5.8 & & Cash flow positive & 20 & $59 \%$ & \\
\hline Donate & 5.0 & & Client paying or letter of intent & 19 & $56 \%$ & \\
\hline Earn money & 5.7 & & Client potential & 29 & $85 \%$ & \\
\hline Job creation & 5.0 & & Employee or management hired & 27 & $75 \%$ & \\
\hline Productivity improve & 6.2 & & Filed federal taxes & 13 & $38 \%$ & \\
\hline Return on investment (ROI) & 4.8 & & Filed employee ID & 15 & $45 \%$ & \\
\hline Supply chain integration & 5.6 & & Incorporated as a legal entity & 28 & $78 \%$ & \\
\hline Training provide & 6.0 & & Materials or inventory purchased & 27 & $75 \%$ & \\
\hline Social value & 5.9 & 5.9 & Patent filed/granted & 10 & $28 \%$ & \\
\hline Community development improve & 6.4 & & Pilot implemented & 28 & $80 \%$ & \\
\hline Education improve & 6.3 & & Professionals (lawyer/account) & 19 & $53 \%$ & \\
\hline Health improve & 5.6 & & Prototype built & 28 & $80 \%$ & \\
\hline Quality of life improve & 6.6 & & Replication model in place & 28 & $80 \%$ & \\
\hline Responsible business practices & 6.3 & & Scale achieved & 26 & $74 \%$ & \\
\hline Social return on investment (SROI) & 6.0 & & Space rented or secured & 21 & $60 \%$ & \\
\hline Water improve & 3.8 & & Started operations & 30 & $86 \%$ & \\
\hline Environmental value & 5.0 & 4.9 & Website & 30 & $83 \%$ & \\
\hline Ecofriendly products & 5.6 & & & & & \\
\hline Energy savings & 4.7 & & Competitive advantage & & & $72 \%$ \\
\hline Greenhouse gas emission reduction & 4.6 & & Actually launch $(n=72)$ & 30 & $42 \%$ & \\
\hline Recycle & 5.0 & & & & & \\
\hline
\end{tabular}

* Value creation is $33 \%$ economic value, $33 \%$ environmental value \& $33 \%$ social value

** Competitive advantage is $50 \%$ value creation out of $7 \& 50 \%$ venture development

${ }^{1}$ Average is the average Likert Scale out of 7 where $7=$ Strongly agree; $6=$ Moderately agree; $5=$ Slightly agree; $4=$ Neutral; $3=$ Slightly disagree; $2=$ Moderately disagree; $1=$ Strongly disagree

${ }^{2}$ Satisfaction is the average Likert Scale out of 7 of satisfaction with each type of value

${ }^{3}$ Number is the number of social ventures in which the activity is achieved or in progress; ${ }^{4}$ Percent is the percentage of social ventures in which activity is achieved or is in progress

${ }^{5}$ Percentavg is the average percentage of venture development activities or competitive advantage per social venture 
of the nascent social venture. The average of value creation and venture development is the competitive advantage of the social venture which is $15 \%$. This indicates that on average each social venture has $15 \%$ of the venture development activities and value creation types.

Table 9 details the descriptive statistics of the dependent variable from the exploratory survey instrument. Value creation assesses the extent to which the survey respondent agrees on a seven point Likert scale that the social venture is creating value now or plans to create value in the future through each of these individual measures of economic, social, and environmental value creation. As seen in the business plans, social value is most created (5.9), followed by economic value (5.5), and environmental value (5.0). Value creation (5.5) is the average of social, economic, and environmental value. The survey also assesses the overall satisfaction with the level of social (5.9), economic (5.5), and environmental value (4.9) achieved on a 7 point Likert scale and the results are almost identical to the averages calculated. The overall satisfaction with value creation is 5.4, compared to general value creation of 5.5.

As seen in Table 9, 67\% of venture development activities are in progress or have been completed by survey participants. The most common venture development activities are started operations $(86 \%)$, identification of a potential client $(85 \%)$, and development of a website $(83 \%)$ followed by pilot project $(80 \%)$, prototype $(80 \%)$, and replication model $(80 \%)$. These are also among the most prevalent venture development activities in the business plans. Nevertheless, the percent completed by the survey respondents $(67 \%)$ is 
much greater compared to the business plans (19\%). This could result from self-response bias as more developed ventures are more likely to complete the survey. Alternatively, the measurement of these venture development activities through content analysis is not as obvious as directly asking a venture founder through a survey.

The overall survey competitive advantage is $72 \%$ (average of survey venture development and value creation). The survey also includes the competitive advantage measure launch which identifies the current status of the social venture. Of the 72 ventures that took the survey, 30 ventures or $42 \%$ actually launched.

Independent variables. Table 10 details the descriptive statistics of the independent variables and their components based on the content analysis of the business plans. These independent variables fall into the categories partnerships, resource conditions, and strategy.

Partnerships include five secondary independent variables partnership importance, partnership diversity, public sector partners, private sector partners, and social sector partners. Partnership importance is measured as an indication of partnerships as important to the achievement of social venture goals in the Executive Summary of the business plans. In $42 \%$ of the plans partnerships are considered particularly important. Partnership diversity represents the number of different types of partners of a social venture. The different types of partnerships include alliances with the community, corporations, government, financial institutions, individuals, religious entities, other 
Table 10: Independent variables - Business plans

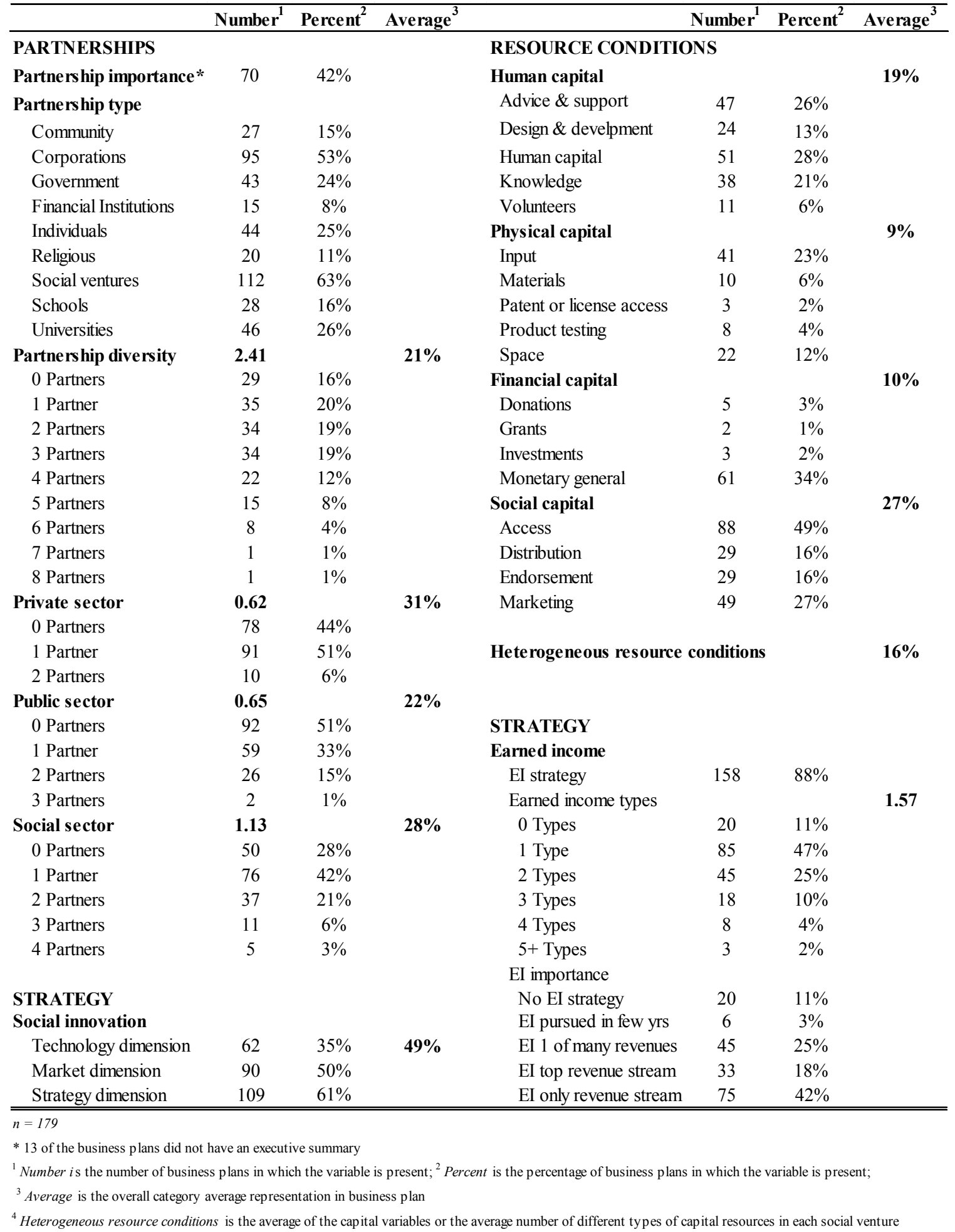


social ventures, schools, and universities. On average, each social venture indicates they have partnerships with 2.41 different types of partners. Each social venture business plan suggests that they have, on average, 0.62 partnerships with the private sector, 0.65 partnerships with the public sector, and 1.13 partnerships with the social sector. Partnerships with different entities of the social sector i.e. the community, individuals, religious entities, or other social ventures are most prevalent.

Resource conditions include the resources that the social ventures gain through partnerships. These resources are divided into human capital, physical capital, financial capital, and social capital. The most common types of human capital are general human capital (28\%), advice \& support (26\%), and knowledge (21\%). Physical capital resources gained through partnerships that are most frequently mentioned includes inputs $(23 \%)$ and space $(12 \%)$. The financial capital most obtained through partnerships is general monetary support ( $34 \%$ of plans). Specific types of financial capital like donations $(3 \%)$, investments $(2 \%)$, and grants $(1 \%)$ are much less frequently mentioned. The social capital variables most prevalent in business plans are access (49\%) to a certain market or population provided by a partner and assistance with marketing (27\%) of social venture products or services. Each capital variable is calculated as the average number of different types of resources in that category. Social capital is the type of capital resource most gained through partnerships as it is prevalent in $27 \%$ of the ventures, followed by human capital (19\%), financial capital (10\%) and physical capital (9\%). Heterogeneous resource conditions is the average percentage of different types of capital resources gained through partnerships in each social venture. 
Social venture strategy consists of a focus on social innovation and earned income. Three dimensions of social innovation are identified through the content analysis of the business plans: strategy, market, and technology. Social ventures focusing on the strategy component of social innovation or an innovative business model are found in $61 \%$ of the plans. This is followed by focusing on a new market (50\%) and finally using technology (35\%) in a new or innovative way. On average, the social ventures use 1.48 different types of these three innovative strategies to achieve their goals. Earned income is another strategic focus measured through the content analysis. As seen in the Table 10, $88 \%$ of the social ventures are currently using or plan to develop an earned income strategy. Most of the social ventures develop one (47\%) or two (25\%) different products or services that help them earn revenue. On average 1.57 types of earned income revenue streams are seen per venture. In regards to earned income importance, earned income is the only type of revenue stream or one of the top revenue streams of revenue for $42 \%$ and $18 \%$ of social ventures respectively.

Table 11 details the descriptive statistics of the independent variables from the exploratory survey instrument. Overall, partnerships are considered extremely important to the achievement of social venture goals, as the average score was 6.5 on a 7 point Likert Scale. The average partnership diversity is 5.7 which indicate that 5.7 different types of partnerships are considered to be important to the venture. Social sector partners are considered to be the most important (5.8), followed by public (5.6) and private sector partners (5.4). These variables assess the average Likert score, indicating importance of the different types of partners operating in each sector. These findings demonstrate 
Table 11: Independent variables - Survey instrument

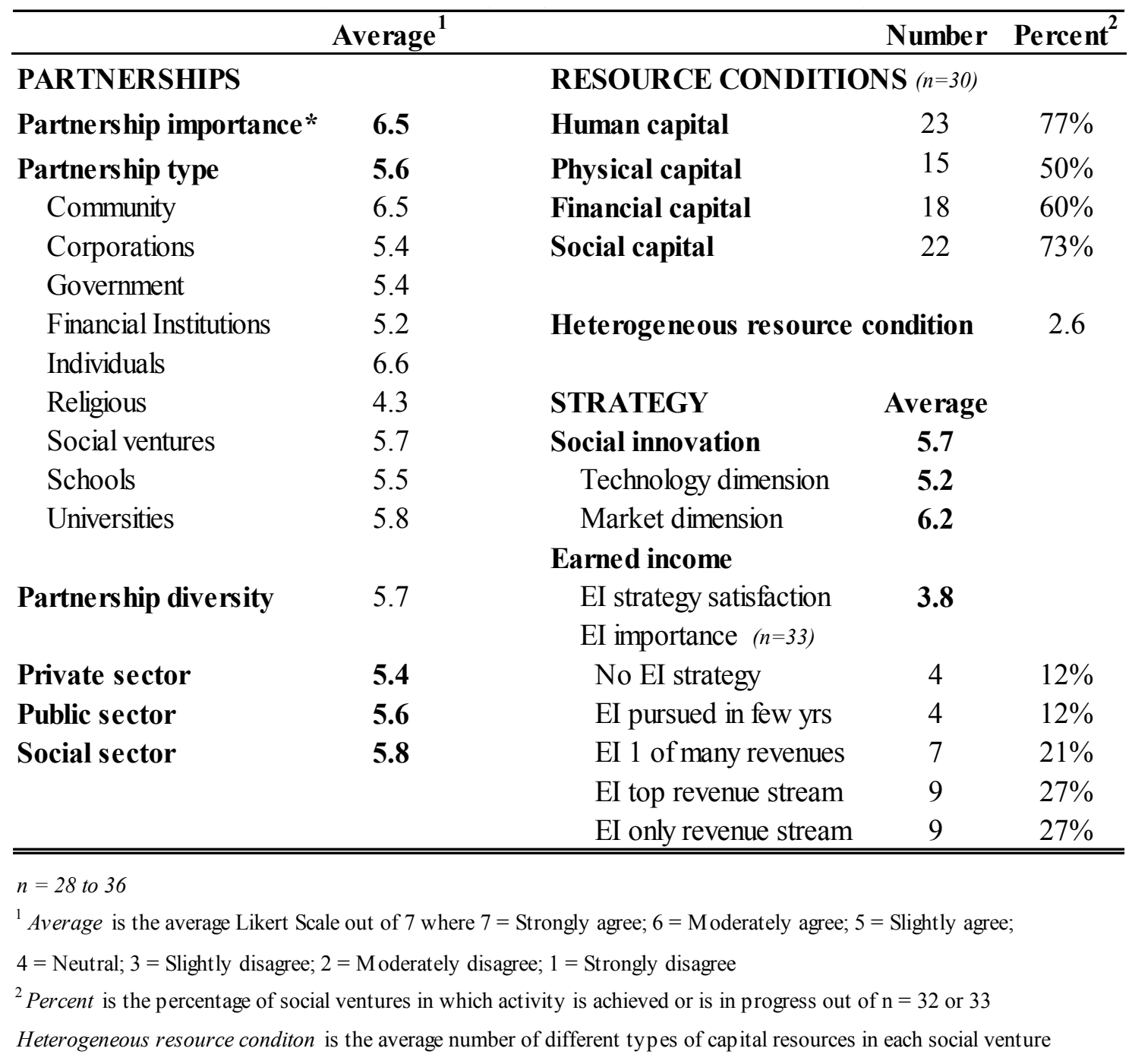

similar trends to what is seen in the content analysis of the business plans. The most common type of resource is human capital (seen in $77 \%$ of ventures), followed by social capital (73\%), financial capital (60\%), and physical capital (50\%). On average the heterogeneous resource condition of each social venture is 2.6 which indicate that each venture has 2.6 different types of capital. 
In regards to strategy, market based social innovation (6.2) is more prevalent than technology based social innovation (5.2), a similar finding as in the business plans. The overall satisfaction with earned income is relatively low (3.8 on a 7 point Likert scale), which could suggest that the earned income strategy is not as developed as the survey respondent would like. This interpretation is suggested since earned income is the only revenue stream or the top revenue stream for $54 \%$ of ventures.

Control variables. Table 12 details the descriptive statistics of the control variables and their components based on the business plan sample. The social venture types include nonprofit, for-profit, and hybrid ventures which respectively make up 49\%, 41\%, and 9\% of the sample. Hybrid ventures have both nonprofit and for-profit components. Impact is the area in which the social venture has the most impact, and includes poverty alleviation (34\%), health (25\%), education (18\%), environment (15\%), and the nonprofit sector $(9 \%)$ in general. The geographic area the social ventures primarily have activities is the United States (50\%), but also includes Asia (17\%), Latin America (15\%), Africa (13\%), and Global or numerous locations (5\%). Revenue in year one controls for venture size. Although $22 \%$ of ventures do not report any revenue in year one, $25 \%$ expect to earn up to $\$ 50,000,26 \%$ expect to attain $\$ 50,001$ to $\$ 250,000$ in revenue in year one, and $27 \%$ expect to attain more than $\$ 250,001$ in revenue in year one. The average founder start-up experience is 0.75 ventures started per social venture. 
Table 12: Control variables - Business Plans

\begin{tabular}{|c|c|c|c|c|c|c|}
\hline & Number $^{1}$ & Percent $^{2}$ & & Number $^{1}$ & Percent $^{2}$ & Average $^{3}$ \\
\hline \multicolumn{3}{|l|}{ Social venture type } & \multicolumn{4}{|c|}{ Business plan competition participation year } \\
\hline Nonprofit & 88 & $49 \%$ & 2004 & 3 & $2 \%$ & \\
\hline Forprofit & 74 & $41 \%$ & 2005 & 1 & $1 \%$ & \\
\hline Hybrid & 17 & $9 \%$ & 2007 & 22 & $12 \%$ & \\
\hline Impact & & & 2008 & 63 & $35 \%$ & \\
\hline Education & 33 & $18 \%$ & 2009 & 90 & $50 \%$ & \\
\hline Environment & 26 & $15 \%$ & Business plan sponsor & & & \\
\hline Health & 44 & $25 \%$ & Baruch & 2 & $1 \%$ & \\
\hline Nonprofit & 16 & $9 \%$ & BYU & 6 & $3 \%$ & \\
\hline Poverty alleviation & 60 & $34 \%$ & FIU & 9 & $5 \%$ & \\
\hline \multicolumn{3}{|c|}{ Geographic area of activities } & Gonzaga & 13 & $7 \%$ & \\
\hline Africa & 24 & $13 \%$ & MIT & 1 & $1 \%$ & \\
\hline Asia & 30 & $17 \%$ & Seattle Pacific University & 42 & $23 \%$ & \\
\hline Global & 9 & $5 \%$ & UT Austin & 102 & $57 \%$ & \\
\hline Latin America & 27 & $15 \%$ & University of Washington & 2 & $1 \%$ & \\
\hline United States & 89 & $50 \%$ & William James Foundation & 2 & $1 \%$ & \\
\hline Venture size & & & Business plan completeness & & & \\
\hline Revenue in Year 1 & & & Balance Sheet & 59 & $33 \%$ & 4.65 \\
\hline None reported & 40 & $22 \%$ & Cash flow statement & 57 & $32 \%$ & \\
\hline$\$ 1-\$ 50,000$ & 44 & $25 \%$ & Financial section & 158 & $88 \%$ & \\
\hline$\$ 50,001-\$ 250,000$ & 46 & $26 \%$ & Income statement & 122 & $68 \%$ & \\
\hline$\$ 250,001-\$ 500,000$ & 24 & $13 \%$ & Management section & 133 & $74 \%$ & \\
\hline$\$ 500,001+$ & 25 & $14 \%$ & Marketing/strategy section & 177 & $99 \%$ & \\
\hline Start-up experience & 0.75 & & Social impact section & 127 & $71 \%$ & \\
\hline
\end{tabular}


Table 13: Demographic characteristics - Survey instrument

\begin{tabular}{|c|c|c|c|c|c|}
\hline & Number $^{1}$ & Percent $^{2}$ & & Number $^{1}$ & Percent $^{2}$ \\
\hline \multicolumn{3}{|c|}{ Social venture type $(n=35)$} & \multicolumn{3}{|l|}{ Highest completed degree $(n=64)$} \\
\hline Nonprofit & 15 & $43 \%$ & High school & 7 & $11 \%$ \\
\hline Forprofit & 14 & $40 \%$ & Undergraduate & 25 & $39 \%$ \\
\hline Economic focus & 3 & $9 \%$ & Masters & 28 & $44 \%$ \\
\hline Social focus & 3 & $9 \%$ & $\mathrm{PhD}$ & 4 & $6 \%$ \\
\hline Econ/social focus & 8 & $24 \%$ & & & \\
\hline \multirow[t]{2}{*}{ Hybrid } & 6 & $17 \%$ & Work Experience $(n=62)$ & & \\
\hline & & & None & 6 & $10 \%$ \\
\hline \multicolumn{3}{|c|}{ Business plan competitions - \# participated in } & Up to 4 years & 25 & $40 \%$ \\
\hline 1 & 41 & $66 \%$ & $5-9$ years & 15 & $24 \%$ \\
\hline 2 & 9 & $15 \%$ & $10-20$ years & 11 & $18 \%$ \\
\hline 3 & 2 & $3 \%$ & $21+$ years & 5 & $8 \%$ \\
\hline 4 & 4 & $6 \%$ & & & \\
\hline \multirow[t]{2}{*}{5 or more } & 6 & $10 \%$ & Gender survey respondent $(n=63)$ & & \\
\hline & & & Male & 31 & $49 \%$ \\
\hline \multicolumn{3}{|c|}{ Amount Win in Competition $(n=52)$} & Female & 32 & $51 \%$ \\
\hline Zero & 17 & $33 \%$ & & & \\
\hline$\$ 1-\$ 5,000$ & 15 & $29 \%$ & Race survey respondent $(n=61)$ & & \\
\hline$\$ 5,001-\$ 9,999$ & 4 & $8 \%$ & Caucasian & 46 & $75 \%$ \\
\hline$\$ 10,000-\$ 14,999$ & 9 & $17 \%$ & Hispanic & 5 & $8 \%$ \\
\hline \multirow[t]{2}{*}{$\$ 15,000+$} & 7 & $13 \%$ & Asian & 9 & $15 \%$ \\
\hline & & & Other & 1 & $2 \%$ \\
\hline Business plan for class & 25 & $40 \%$ & & & \\
\hline Entrepreneurs in family & 38 & $60 \%$ & & & \\
\hline
\end{tabular}

${ }^{1}$ Number is the number of business plans in which the variable is present

${ }^{2}$ Percent is the percentage of business plans in which the variable is present 
Several variables control for different aspects of the business plan and the respective competition. These include business plan competition participation year, business plan sponsor, and business plan completeness. The majority of the business plans came from competitions with their finals taking place in 2009 (50\%), 2008 (35\%), and 2007 (12\%). Most of the plans came from the competitions at UT Austin (57\%) and Seattle Pacific University (23\%) since these entities provide a complete set of plans for these years. Business plans from the other competitions are obtained by emailing individual past participants to ask for their participation in this research study. Business plan completeness measures the number of different sections included in each plan as a means to assess the sophistication of each plan. These components include the balance sheet, cash flow statement, financial section, income statement, management section, marketing/strategy section, and a social impact section. On average each business plan contains 4.65 out of 7 of these sections.

Table 13 details the descriptive statistics of the demographic variables collected in the survey instrument. These variables provide some insight into the characteristics of the survey respondents and can be used more in future research. The social venture type of survey respondents is similar to that of the content analysis with $43 \%$ nonprofits, $40 \%$ for-profits, and $17 \%$ hybrids. Most survey respondents only participated in one business plan competition (66\%), but $15 \%$ participated in 2 competitions, and $10 \%$ participated in 5 or more competitions. In regards to the business plan competition winnings: $33 \%$ won nothing, $29 \%$ won up to $\$ 5,000,8 \%$ won between $\$ 5,001$ and $\$ 10,000,17 \%$ won between $\$ 10,001$ and $\$ 14,999$, and $13 \%$ won more than $\$ 15,000$. The education level of 
respondents is relatively high as $50 \%$ have completed their master's degree or doctorate and 39\% had completed undergrad. The survey respondents have limited work experience with $50 \%$ having less than four years experience. Most respondents are Caucasian (75\%) followed by Asian (15\%), Hispanic (8\%), and Other (2\%). In terms of gender, the survey respondents are equally divided between males (49\%) and females $(51 \%)$.

\section{Results}

The hypotheses are examined primarily using the business plan data. Since the survey data is merely exploratory given the small sample size, the survey findings are more descriptive and provide a basis for future research. Nevertheless, some of the hypotheses are examined using variables from the business plan data with launch from the survey data as the dependent variable. The results are summarized below and in Tables 14 to 17 and in Figure 3.

Hypothesis 1a is partially supported that partnerships are important for all types of nascent social ventures. This hypothesis assesses whether partnerships are important for social ventures and if this importance differs across social ventures with distinct legal structures. The business plan descriptive statistics suggest that partnerships are important for $42 \%$ of social ventures. In other words, $42 \%$ of social ventures mention partnerships in their business plan Executive Summary as important to the achievement of social venture goals and mission. Nevertheless, Crosstabs and Chi Square tests indicate that 
this difference is not significant across social venture type (Chi Square $=0.33$ ) as seen in Table 14. Thus according to the business plan data partnerships are important for $42 \%$ of social ventures, but this difference is not significant across social venture type.

Nevertheless, the exploratory survey data suggests that partnerships are very important to social ventures as on average respondents rated partnership importance 6.5 on a 7 point Likert scale. The exploratory survey also suggests that hybrid ventures are significantly less likely to emphasize partnerships as important to achieving venture goals, than nonprofit ventures as seen in Table 14. ANOVA procedures are used to analyze the data and the F-test of 3.23 is significant at 0.05 . Nevertheless, these results are based on a sample size of 35 ventures of which only six are hybrid ventures. In the survey, most of these ventures (24) strongly agree that partnerships are important to the achievement of social venture goals. Thus, the fact that half (three) of the hybrid ventures did not strongly agree impacts these findings. These findings could result from the fact that hybrid ventures are generally composed of both nonprofit and for-profit components which each emphasize partnerships differently. However, the current data are insufficient to distinguish between the degree of hybridness of these social ventures. Future survey or qualitative research can gain deeper insight into how the economic or social focus of hybrid ventures impacts the importance of partnerships. In addition, increasing the number of hybrid ventures in future survey research can help better understand these results. 


\section{Table 14: Partnership importance to social ventures}

\begin{tabular}{lccc}
\hline & Nonprofit & For-Profit & Hybrid \\
\hline Business Plans & & & \\
Important & 39 & 23 & 8 \\
Not Important & 45 & 43 & 9 \\
\hline Survey & 15 & 14 & 6 \\
Mean & $6.87^{\mathrm{b}}$ & 6.50 & $5.67^{\mathrm{a}}$ \\
Standard deviaion & 45 & 43 & 9 \\
\hline Business plans: $p=0.326 ; n=167$ & & \\
Survey: $n=35$. Means with different superscripts are significantly different \\
using One-Way ANOVA and LSD pairwise comparison procedure, $p<0.05$
\end{tabular}

Hypothesis $1 \mathrm{~b}$ is not supported that nonprofit social ventures have a greater competitive advantage than hybrid and for-profit social ventures. The business plan results suggest that both nonprofit and for-profit social ventures have significantly less of a competitive advantage overall (14.07 and 15.62 respectively) as well as less value creation, economic value, and environmental value than hybrid social ventures (competitive advantage 22.16, $p<0.05)$ as seen in Table 15 . Thus, hybrid social ventures have a significantly greater ( $p$ $<0.05)$ competitive advantage than nonprofit and for-profit social ventures. In the case of environmental value, hybrid ventures have a significantly greater advantage than nonprofit social ventures ( 21.18 vs. 7.27 respectively, $\mathrm{p}<0.05)$, while nonprofit social ventures have a significantly smaller advantage than for-profit ventures ( 7.27 vs. 15.68 respectively, $\mathrm{p}<0.01$ ). The greater advantages of hybrid ventures could result from the fact that hybrid ventures are able to take advantage of the benefits of both for-profit and nonprofit legal structures. However the low number of hybrid ventures $(n=17)$ in the business plan sample could also be impacting these results. Thus the business plan data significantly suggests that hybrid ventures have a greater competitive advantage than for- 
profit and nonprofit ventures. The exploratory survey results are not significant as seen in Table 15.

Future research can examine in detail why social ventures with hybrid legal structures might generate more of a competitive advantage than nonprofit and for-profit social ventures. Is it really due to taking advantage of the benefits of both legal structures in one entity or are there other underlying factors that lead to this advantage? Why are hybrid social ventures more related to certain types of competitive advantage (value creation, economic value) than others (venture development)?

Table 15: Social venture structure and competitive advantage

\begin{tabular}{lcccccc}
\hline & \multicolumn{2}{c}{ Nonprofit } & \multicolumn{2}{c}{ For-Profit } & \multicolumn{2}{c}{ Hybrid } \\
\cline { 2 - 6 } & Mean & s.d. & Mean & s.d. & Mean & S.d. \\
\hline Business Plans & & & & & & \\
Competitive advantage & $14.07^{\mathrm{b}}$ & 9.25 & $15.62^{\mathrm{b}}$ & 11.10 & $22.16^{\mathrm{a}}$ & 11.00 \\
Venture development & 12.36 & 15.01 & 12.33 & 16.84 & 16.18 & 16.10 \\
Value creation & $15.78^{\mathrm{b}}$ & 9.97 & $18.91^{\mathrm{b}}$ & 12.52 & $28.14^{\mathrm{a}}$ & 13.55 \\
Economic value & $16.48^{\mathrm{b}}$ & 15.69 & $19.43^{\mathrm{b}}$ & 16.83 & $35.29^{\mathrm{a}}$ & 21.30 \\
Social value & 23.58 & 12.20 & 21.62 & 16.72 & 27.94 & 13.64 \\
Environmental value & $7.27^{\mathrm{b}}$ & 15.81 & $15.68^{\mathrm{c}}$ & 23.47 & $21.18^{\mathrm{a}}$ & 23.95 \\
\hline Survey & & & & & & \\
Competitive advantage & 71.00 & 12.78 & 76.96 & 18.12 & 62.54 & 18.24 \\
Venture development & 61.34 & 27.82 & 76.45 & 26.92 & 55.56 & 27.22 \\
Value creation & 80.63 & 11.69 & 79.30 & 22.41 & 69.52 & 17.69 \\
Economic value & 5.53 & 0.99 & 5.77 & 1.48 & 4.60 & 1.52 \\
Social value & 6.20 & 0.56 & 5.86 & 1.56 & 5.40 & 1.52 \\
Environmental value & 5.08 & 1.83 & 4.82 & 2.04 & 4.60 & 1.52 \\
\hline Business plans: $n=179 ;$ Nonprofit $=88$, Forprofit $=74 ;$ Hybrid $=17 ;$ Survey: $n=28-34$. & \\
Means with lower superscripts are significantly greater using One-Way ANOVA and LSD pairwise comparison procedure, $p<0.05$
\end{tabular}


Hypothesis $2 \mathrm{a}$ is supported that partnership diversity is positively associated with heterogeneous resource conditions. This hypothesis assesses whether a greater number of different types of partnerships leads to a more heterogeneous set of resources. In the business plan sample, partnership diversity is strongly significantly positively related to heterogeneous resource conditions $(r=0.74 * * ; p<0.01)$ as seen in the correlations in Table 16. Partnership diversity is also significantly positively related to the different types of resources: human capital $\left(r=0.52^{* *} ; p<0.01\right)$, physical capital $(r=0.42 * * ; p<$ $0.01)$, financial capital $\left(0.44^{* *} ; \mathrm{p}<0.01\right)$, and social capital $(r=0.60 * * ; p<0.01)$.

Figure 3 demonstrates this linear relationship for social ventures with different legal structures. There also is a strong relationship between partnership diversity and heterogeneous resource conditions for nonprofit ventures $\left(r=0.76^{* *}, p<0.01\right)$, for forprofit ventures $\left(r=0.70^{* *}, p<0.01\right)$, and for hybrid ventures $\left(r=0.70^{* *}, p<0.01\right)$ as seen in Figure 3. This suggests that partnership diversity is important for social ventures of all different legal structures in order to achieve heterogeneous resource conditions. In addition, heterogeneous resource conditions is strongly related to all types of partnerships with private sector partners $\left(r=0.48^{* *}, p<0.01\right)$, public sector partners $(r$ $=0.59 * *, p<0.01)$, and social sector partners $(r=0.60 * *, p<0.01)$. At the same time, all the different capital components of heterogeneous resource conditions are strongly significantly positively related to private, public, and social sector partners at the $p<$ 0.01 level. 
Table 16: Correlations - Business plans

\begin{tabular}{|c|c|c|c|c|c|c|c|c|c|c|c|c|}
\hline & Mean & s.d. & 1 & 2 & 3 & 4 & 5 & 6 & 7 & 8 & 9 & 10 \\
\hline $\begin{array}{l}1 \text { Competitive advantage } \\
\text { P-value }\end{array}$ & 15.48 & 10.41 & 1.00 & & & & & & & & & \\
\hline $\begin{array}{l}2 \text { Venture development } \\
\text { P-value }\end{array}$ & 12.71 & 15.80 & $\begin{array}{l}0.82^{* * *} \\
0.00\end{array}$ & 1.00 & & & & & & & & \\
\hline $\begin{array}{l}3 \text { Value creation } \\
\text { P-value }\end{array}$ & 18.24 & 11.91 & $\begin{array}{l}0.65^{\text {** }} \\
0.00 \\
\end{array}$ & $\begin{array}{l}0.11 \\
0.15\end{array}$ & 1.00 & & & & & & & \\
\hline $\begin{array}{l}4 \text { Economic value } \\
\text { P-value }\end{array}$ & 19.48 & 17.48 & $\begin{array}{l}0.46^{* *} \\
0.00\end{array}$ & $\begin{array}{l}0.06 \\
0.44\end{array}$ & $\begin{array}{l}0.73^{* *} \\
0.00 \\
\end{array}$ & 1.00 & & & & & & \\
\hline $\begin{array}{l}5 \text { Social value } \\
\text { P-value }\end{array}$ & 23.18 & 14.40 & $\begin{array}{l}0.47^{* * *} \\
0.00 \\
\end{array}$ & $\begin{array}{l}0.17^{*} \\
0.02 \\
\end{array}$ & $\begin{array}{l}0.60^{* *} \\
0.00 \\
\end{array}$ & $\begin{array}{l}0.31^{* *} \\
0.00 \\
\end{array}$ & 1.00 & & & & & \\
\hline $\begin{array}{l}6 \text { Environmental value } \\
\text { P-value }\end{array}$ & 12.07 & 20.60 & $\begin{array}{l}0.42^{* *} \\
0.00 \\
\end{array}$ & $\begin{array}{l}0.02 \\
0.81 \\
\end{array}$ & $\begin{array}{l}0.70^{* *} \\
0.00 \\
\end{array}$ & $\begin{array}{l}0.20^{* *} \\
0.01 \\
\end{array}$ & $\begin{array}{l}0.07 \\
0.32 \\
\end{array}$ & 1.00 & & & & \\
\hline $\begin{array}{l}7 \text { Partnership importance } \\
\text { P-value }\end{array}$ & 0.42 & 0.50 & $\begin{array}{l}0.25^{* *} \\
0.00 \\
\end{array}$ & $\begin{array}{l}0.21^{* *} \\
0.01\end{array}$ & $\begin{array}{l}0.16^{*} \\
0.04 \\
\end{array}$ & $\begin{array}{l}0.16^{*} \\
0.04 \\
\end{array}$ & $\begin{array}{l}0.17^{*} \\
0.03 \\
\end{array}$ & $\begin{array}{l}0.02 \\
0.80 \\
\end{array}$ & 1.00 & & & \\
\hline $\begin{array}{l}8 \text { Partnership diversity } \\
\text { P-value }\end{array}$ & 26.75 & 19.83 & $\begin{array}{l}0.31^{* *} \\
0.00\end{array}$ & $\begin{array}{l}0.27 * * \\
0.00\end{array}$ & $\begin{array}{l}0.19^{*} \\
0.01\end{array}$ & $\begin{array}{l}0.20^{*} \\
0.01\end{array}$ & $\begin{array}{l}0.27 * * \\
0.00\end{array}$ & $\begin{array}{c}-0.03 \\
0.65 \\
\end{array}$ & $\begin{array}{l}0.49^{* *} \\
0.00\end{array}$ & 1.00 & & \\
\hline $\begin{array}{l}9 \text { Private sector partners } \\
\text { P-value }\end{array}$ & 31.01 & 29.55 & $\begin{array}{l}0.24 * * \\
0.00\end{array}$ & $\begin{array}{l}0.20^{* *} \\
0.01\end{array}$ & $\begin{array}{l}0.15^{*} \\
0.04\end{array}$ & $\begin{array}{l}0.10 \\
0.18\end{array}$ & $\begin{array}{l}0.19^{*} \\
0.01\end{array}$ & $\begin{array}{l}0.05 \\
0.54 \\
\end{array}$ & $\begin{array}{l}0.36^{* *} \\
0.00 \\
\end{array}$ & $\begin{array}{l}0.65^{* *} \\
0.00 \\
\end{array}$ & 1.00 & \\
\hline $\begin{array}{l}10 \text { Public sector partners } \\
\text { P-value }\end{array}$ & 21.79 & 25.54 & $\begin{array}{l}0.29 * * \\
0.00\end{array}$ & $\begin{array}{l}0.26^{* *} \\
0.00\end{array}$ & $\begin{array}{l}0.17^{*} \\
0.03\end{array}$ & $\begin{array}{l}0.11 \\
0.15\end{array}$ & $\begin{array}{l}0.22 * * \\
0.00\end{array}$ & $\begin{array}{l}0.04 \\
0.61 \\
\end{array}$ & $\begin{array}{l}0.35^{* *} \\
0.00\end{array}$ & $\begin{array}{l}0.77 * * \\
0.00\end{array}$ & $\begin{array}{l}0.34 * * \\
0.00\end{array}$ & 1.00 \\
\hline $\begin{array}{l}11 \text { Social sector partners } \\
\text { P-value }\end{array}$ & 28.35 & 24.63 & $\begin{array}{l}0.19^{* *} \\
0.01\end{array}$ & $\begin{array}{l}0.17^{*} \\
0.03\end{array}$ & $\begin{array}{l}0.12 \\
0.11\end{array}$ & $\begin{array}{l}0.21^{* *} \\
0.00\end{array}$ & $\begin{array}{l}0.21 * * \\
0.01\end{array}$ & $\begin{array}{c}-0.12 \\
0.11 \\
\end{array}$ & $\begin{array}{l}0.41^{* *} \\
0.00\end{array}$ & $\begin{array}{l}0.83 * * \\
0.00\end{array}$ & $\begin{array}{l}0.31^{* *} \\
0.00\end{array}$ & $\begin{array}{l}0.40^{* *} \\
0.00\end{array}$ \\
\hline $\begin{array}{l}2 \text { Social innovation } \\
\text { P-value } \\
\end{array}$ & 48.60 & 32.43 & $\begin{array}{l}0.30^{\text {** }} \\
0.00 \\
\end{array}$ & $\begin{array}{l}0.38^{* *} \\
0.00 \\
\end{array}$ & $\begin{array}{l}0.02 \\
0.78 \\
\end{array}$ & $\begin{array}{l}-0.01 \\
0.92 \\
\end{array}$ & $\begin{array}{l}0.09 \\
0.23 \\
\end{array}$ & $\begin{array}{l}-0.02 \\
0.80 \\
\end{array}$ & $\begin{array}{l}0.09 \\
0.28 \\
\end{array}$ & $\begin{array}{l}0.25^{* *} \\
0.00 \\
\end{array}$ & $\begin{array}{l}0.26^{* *} \\
0.00 \\
\end{array}$ & $\begin{array}{l}0.22^{* *} \\
0.00 \\
\end{array}$ \\
\hline $\begin{array}{l}13 \text { Earned income streams } \\
\text { P-value }\end{array}$ & 1.57 & 1.22 & $\begin{array}{l}0.19^{*} \\
0.01\end{array}$ & $\begin{array}{l}0.18^{*} \\
0.02 \\
\end{array}$ & $\begin{array}{l}0.10 \\
0.18 \\
\end{array}$ & $\begin{array}{l}0.11 \\
0.16 \\
\end{array}$ & $\begin{array}{l}0.12 \\
0.11 \\
\end{array}$ & $\begin{array}{l}0.00 \\
0.98 \\
\end{array}$ & $\begin{array}{l}0.01 \\
0.92 \\
\end{array}$ & $\begin{array}{l}0.14 \\
0.06 \\
\end{array}$ & $\begin{array}{l}0.14 \\
0.06 \\
\end{array}$ & $\begin{array}{l}0.07 \\
0.32 \\
\end{array}$ \\
\hline $\begin{array}{l}14 \text { Earned income import } \\
\text { P-value } \\
\end{array}$ & 2.77 & 1.33 & $\begin{array}{l}0.10 \\
0.18 \\
\end{array}$ & $\begin{array}{l}-0.02 \\
0.83 \\
\end{array}$ & $\begin{array}{l}0.20^{* *} \\
0.01 \\
\end{array}$ & $\begin{array}{l}0.22^{* *} \\
0.00 \\
\end{array}$ & $\begin{array}{l}-0.02 \\
0.84 \\
\end{array}$ & $\begin{array}{l}0.16^{*} \\
0.03 \\
\end{array}$ & $\begin{array}{l}-0.10 \\
0.18 \\
\end{array}$ & $\begin{array}{l}-0.20^{* *} \\
0.01 \\
\end{array}$ & $\begin{array}{l}0.03 \\
0.70 \\
\end{array}$ & $\begin{array}{l}-0.28^{* *} \\
0.00 \\
\end{array}$ \\
\hline $\begin{array}{l}15 \text { Human capital } \\
\text { P-value } \\
\end{array}$ & 19.11 & 21.70 & $\begin{array}{l}0.16^{*} \\
0.03 \\
\end{array}$ & $\begin{array}{l}0.17^{*} \\
0.03 \\
\end{array}$ & $\begin{array}{l}0.06 \\
0.41 \\
\end{array}$ & $\begin{array}{l}0.05 \\
0.54 \\
\end{array}$ & $\begin{array}{l}0.12 \\
0.11 \\
\end{array}$ & $\begin{array}{l}-0.02 \\
0.83 \\
\end{array}$ & $\begin{array}{l}0.43 * * \\
0.00 \\
\end{array}$ & $\begin{array}{l}0.52^{* *} \\
0.00 \\
\end{array}$ & $\begin{array}{l}0.25^{* *} \\
0.00 \\
\end{array}$ & $\begin{array}{l}0.46^{* *} \\
0.00 \\
\end{array}$ \\
\hline $\begin{array}{l}16 \text { Physical capital } \\
\text { P-value } \\
\end{array}$ & 9.39 & 16.19 & $\begin{array}{l}0.03 \\
0.71 \\
\end{array}$ & $\begin{array}{l}0.00 \\
0.97 \\
\end{array}$ & $\begin{array}{l}0.05 \\
0.55 \\
\end{array}$ & $\begin{array}{l}0.02 \\
0.79 \\
\end{array}$ & $\begin{array}{l}0.12 \\
0.11 \\
\end{array}$ & $\begin{array}{r}-0.03 \\
0.74 \\
\end{array}$ & $\begin{array}{l}0.30^{* *} \\
0.00 \\
\end{array}$ & $\begin{array}{l}0.42^{* *} \\
0.00 \\
\end{array}$ & $\begin{array}{l}0.29^{* *} \\
0.00 \\
\end{array}$ & $\begin{array}{l}0.30^{\text {** }} \\
0.00\end{array}$ \\
\hline $\begin{array}{l}17 \text { Financial capital } \\
\text { P-value } \\
\end{array}$ & 9.92 & 15.09 & $\begin{array}{l}0.06 \\
0.47 \\
\end{array}$ & $\begin{array}{l}0.03 \\
0.67 \\
\end{array}$ & $\begin{array}{l}0.05 \\
0.48 \\
\end{array}$ & $\begin{array}{l}0.10 \\
0.20\end{array}$ & $\begin{array}{l}0.13 \\
0.08 \\
\end{array}$ & $\begin{array}{c}-0.08 \\
0.29 \\
\end{array}$ & $\begin{array}{l}0.34^{* *} \\
0.00 \\
\end{array}$ & $\begin{array}{l}0.44^{* *} \\
0.00 \\
\end{array}$ & $\begin{array}{l}0.36^{* *} \\
0.00 \\
\end{array}$ & $\begin{array}{l}0.27^{* *} \\
0.00 \\
\end{array}$ \\
\hline $\begin{array}{l}18 \text { Social capital } \\
\text { P-value } \\
\end{array}$ & 27.23 & 24.33 & $\begin{array}{l}0.21^{* *} \\
0.01 \\
\end{array}$ & $\begin{array}{l}0.20^{* *} \\
0.01\end{array}$ & $\begin{array}{l}0.10 \\
0.19 \\
\end{array}$ & $\begin{array}{l}0.08 \\
0.32 \\
\end{array}$ & $\begin{array}{l}0.24 * * \\
0.00 \\
\end{array}$ & $\begin{array}{l}-0.06 \\
0.43 \\
\end{array}$ & $\begin{array}{l}0.29^{* *} \\
0.00 \\
\end{array}$ & $\begin{array}{l}0.60^{* *} \\
0.00 \\
\end{array}$ & $\begin{array}{l}0.40^{* *} \\
0.00 \\
\end{array}$ & $\begin{array}{l}0.49^{* *} \\
0.00 \\
\end{array}$ \\
\hline $\begin{array}{l}19 \text { Heterogeneous resources } \\
\text { P-value }\end{array}$ & 16.41 & 13.17 & $\begin{array}{l}0.19^{*} \\
0.01\end{array}$ & $\begin{array}{l}0.17^{*} \\
0.02 \\
\end{array}$ & $\begin{array}{l}0.10 \\
0.18\end{array}$ & $\begin{array}{l}0.09 \\
0.25\end{array}$ & $\begin{array}{l}0.24 * * \\
0.00\end{array}$ & $\begin{array}{l}-0.07 \\
0.39 \\
\end{array}$ & $\begin{array}{l}0.50^{* *} \\
0.00\end{array}$ & $\begin{array}{l}0.74 * * \\
0.00\end{array}$ & $\begin{array}{l}0.48^{* *} \\
0.00\end{array}$ & $\begin{array}{l}0.59^{* *} \\
0.00\end{array}$ \\
\hline
\end{tabular}


Table 16: Correlations - Business plans continued

\begin{tabular}{|c|c|c|c|c|c|c|c|c|c|c|}
\hline & 10 & 11 & 12 & 13 & 14 & 15 & 16 & 17 & 18 & 19 \\
\hline $\begin{array}{l}10 \text { Public sector partners } \\
\text { P-value }\end{array}$ & 1.00 & & & & & & & & & \\
\hline 11 Social sector partners & $0.40^{* *}$ & 1.00 & & & & & & & & \\
\hline P-value & 0.00 & & & & & & & & & \\
\hline 12 Social innovation & $0.22 * *$ & 0.14 & 1.00 & & & & & & & \\
\hline P-value & 0.00 & 0.07 & & & & & & & & \\
\hline 13 Earned income streams & 0.07 & 0.11 & 0.08 & 1.00 & & & & & & \\
\hline P-value & 0.32 & 0.13 & 0.30 & & & & & & & \\
\hline 14 Earned income import & $-0.28 * *$ & $-0.15^{*}$ & -0.09 & $0.38 * *$ & 1.00 & & & & & \\
\hline P-value & 0.00 & 0.04 & 0.25 & 0.00 & & & & & & \\
\hline 15 Human capital & $0.46^{* *}$ & $0.43^{* *}$ & 0.13 & -0.05 & -0.21 & 1.00 & & & & \\
\hline P-value & 0.00 & 0.00 & 0.08 & 0.52 & 0.00 & & & & & \\
\hline 16 Physical capital & $0.30^{* *}$ & $0.35^{* *}$ & 0.08 & -0.09 & $-0.19 * *$ & $0.40 * *$ & 1.00 & & & \\
\hline P-value & 0.00 & 0.00 & 0.27 & 0.26 & 0.01 & 0.00 & & & & \\
\hline 17 Financial capital & $0.27 * *$ & $0.36^{* *}$ & 0.06 & 0.00 & -0.14 & $0.29 * *$ & $0.28 * *$ & 1.00 & & \\
\hline P-value & 0.00 & 0.00 & 0.41 & 0.96 & 0.07 & 0.00 & 0.00 & & & \\
\hline 18 Social capital & $0.49 * *$ & $0.46^{* *}$ & $0.28 *$ & $0.18^{*}$ & -0.04 & $0.25^{* *}$ & $0.29 * *$ & $0.17 *$ & 1.00 & \\
\hline P-value & 0.00 & 0.00 & 0.00 & 0.01 & 0.59 & 0.00 & 0.00 & 0.02 & & \\
\hline 19 Heterogeneous resources & $0.59 * *$ & $0.60^{* *}$ & $0.23 *$ & 0.04 & $-0.20 * *$ & $0.73^{* *}$ & $0.69^{* *}$ & $0.57^{* *}$ & $0.70 * *$ & 1.00 \\
\hline P-value & 0.00 & 0.00 & 0.00 & 0.61 & 0.01 & 0.00 & 0.00 & 0.00 & 0.00 & \\
\hline
\end{tabular}


Table 17: Correlations - Survey instrument

\begin{tabular}{|c|c|c|c|c|c|c|c|c|c|c|c|c|c|c|}
\hline & Mean & s.d. & 1 & 2 & 3 & 4 & 5 & 6 & 7 & 8 & 9 & 10 & 11 & 12 \\
\hline $\begin{array}{l}1 \text { Competitive advantage } \\
\text { P-value }\end{array}$ & 71.91 & 16.05 & 1.00 & & & & & & & & & & & \\
\hline $\begin{array}{l}2 \text { Venture development } \\
\text { P-value } \\
\end{array}$ & 66.90 & 27.87 & $\begin{array}{l}0.85^{* *} \\
0.00\end{array}$ & 1.00 & & & & & & & & & & \\
\hline $\begin{array}{l}\text { Value creation } \\
\text { P-value }\end{array}$ & 78.43 & 17.38 & $\begin{array}{l}0.46^{* *} \\
0.01\end{array}$ & $\begin{array}{c}-0.09 \\
0.64\end{array}$ & 1.00 & & & & & & & & & \\
\hline $\begin{array}{l}4 \text { Economic value } \\
\text { P-value }\end{array}$ & 5.55 & 0.92 & $\begin{array}{l}0.35 \\
0.07\end{array}$ & $\begin{array}{l}0.16 \\
0.44\end{array}$ & $\begin{array}{l}0.45^{*} \\
0.02\end{array}$ & 1.00 & & & & & & & & \\
\hline $\begin{array}{l}5 \text { Economic value satisfaction } \\
\text { P-value }\end{array}$ & 5.48 & 1.30 & $\begin{array}{l}0.46^{* *} \\
0.01\end{array}$ & $\begin{array}{l}0.00 \\
0.98\end{array}$ & $\begin{array}{l}0.87^{*} \\
0.00\end{array}$ & $\begin{array}{l}0.32 \\
0.10\end{array}$ & 1.00 & & & & & & & \\
\hline $\begin{array}{l}6 \text { Social value } \\
\text { P-value }\end{array}$ & 6.03 & 0.81 & $\begin{array}{l}0.38^{* *} \\
0.04\end{array}$ & $\begin{array}{l}0.20 \\
0.29\end{array}$ & $\begin{array}{l}0.36^{*} \\
0.05\end{array}$ & $\begin{array}{l}0.56^{* *} \\
0.00\end{array}$ & $\begin{array}{l}0.14 \\
0.47\end{array}$ & 1.00 & & & & & & \\
\hline $\begin{array}{l}7 \text { Social value satisfaction } \\
\text { P-value }\end{array}$ & 5.94 & 1.21 & $\begin{array}{l}0.40^{*} \\
0.02\end{array}$ & $\begin{array}{r}-0.05 \\
0.79\end{array}$ & $\begin{array}{l}0.85^{* *} \\
0.00\end{array}$ & $\begin{array}{l}0.10 \\
0.63\end{array}$ & $\begin{array}{l}0.72^{* *} \\
0.00\end{array}$ & $\begin{array}{l}0.34 \\
0.06\end{array}$ & 1.00 & & & & & \\
\hline 8 Environmental value & 4.99 & 1.80 & $\begin{array}{l}-0.05 \\
0.82\end{array}$ & $\begin{array}{r}-0.24 \\
0.26\end{array}$ & 0.30 & $\begin{array}{l}0.82^{* *} \\
0.00\end{array}$ & $\begin{array}{l}0.09 \\
0.67\end{array}$ & $\begin{array}{l}0.53 * * \\
0.01\end{array}$ & $\begin{array}{c}-0.06 \\
0.78\end{array}$ & 1.00 & & & & \\
\hline $\begin{array}{l}9 \text { Envt value satisfaction } \\
\text { P-value }\end{array}$ & 4.89 & 1.81 & $\begin{array}{l}0.02 \\
0.12 \\
0.10\end{array}$ & $\begin{array}{r}-0.18 \\
0.36\end{array}$ & $\begin{array}{l}0.85^{* *} \\
0.00\end{array}$ & $\begin{array}{l}0.60^{* *} \\
0.00\end{array}$ & $\begin{array}{l}0.56^{* *} \\
0.00\end{array}$ & $\begin{array}{l}0.41^{*} \\
0.03\end{array}$ & $\begin{array}{l}0.52^{* *} \\
0.01\end{array}$ & $\begin{array}{l}0.59^{* *} \\
0.00\end{array}$ & 1.00 & & & \\
\hline $\begin{array}{l}10 \text { Partnership importance } \\
\text { P-value }\end{array}$ & 6.50 & 1.03 & $\begin{array}{c}-0.06 \\
0.73\end{array}$ & $\begin{array}{c}-0.18 \\
0.30\end{array}$ & $\begin{array}{l}0.20 \\
0.27\end{array}$ & $\begin{array}{c}-0.19 \\
0.32\end{array}$ & $\begin{array}{l}0.15 \\
0.40\end{array}$ & $\begin{array}{l}0.27 \\
0.14\end{array}$ & $\begin{array}{l}0.43^{*} \\
0.01\end{array}$ & $\begin{array}{c}-0.14 \\
0.49\end{array}$ & $\begin{array}{c}-0.05 \\
0.81\end{array}$ & 1.00 & & \\
\hline $\begin{array}{l}11 \text { Partnership diversity } \\
\text { P-value }\end{array}$ & 5.69 & 2.24 & $\begin{array}{l}0.05 \\
0.79\end{array}$ & $\begin{array}{r}-0.03 \\
0.87\end{array}$ & $\begin{array}{c}-0.02 \\
0.92\end{array}$ & $\begin{array}{l}0.17 \\
0.42\end{array}$ & $\begin{array}{r}-0.11 \\
0.56\end{array}$ & $\begin{array}{l}0.17 \\
0.20 \\
0.32\end{array}$ & $\begin{array}{l}0.01 \\
0.98\end{array}$ & $\begin{array}{l}0.12 \\
0.59\end{array}$ & $\begin{array}{l}0.11 \\
0.60\end{array}$ & $\begin{array}{c}-0.18 \\
0.33\end{array}$ & 1.00 & \\
\hline $\begin{array}{l}12 \text { Private sector partners } \\
\text { P-value }\end{array}$ & 5.36 & 1.07 & $\begin{array}{l}0.05 \\
0.79 \\
\end{array}$ & $\begin{array}{l}0.06 \\
0.73 \\
\end{array}$ & $\begin{array}{r}-0.07 \\
0.72 \\
\end{array}$ & $\begin{array}{l}0.37 \\
0.06 \\
\end{array}$ & $\begin{array}{c}-0.21 \\
0.25 \\
\end{array}$ & $\begin{array}{l}0.24 \\
0.20 \\
\end{array}$ & $\begin{array}{c}-0.13 \\
0.49 \\
\end{array}$ & $\begin{array}{l}0.23 \\
0.27 \\
\end{array}$ & $\begin{array}{l}0.09 \\
0.65 \\
\end{array}$ & $\begin{array}{c}-0.12 \\
0.50 \\
\end{array}$ & $\begin{array}{l}0.61^{* *} \\
0.00 \\
\end{array}$ & 1.00 \\
\hline $\begin{array}{l}13 \text { Public sector partners } \\
\text { P-value }\end{array}$ & 5.57 & 1.06 & $\begin{array}{c}-0.07 \\
0.69\end{array}$ & $\begin{array}{r}-0.21 \\
0.23\end{array}$ & $\begin{array}{l}0.16 \\
0.37\end{array}$ & $\begin{array}{l}0.001 \\
0.97\end{array}$ & $\begin{array}{l}0.205 \\
0.77\end{array}$ & $\begin{array}{l}0.02 \\
0.91\end{array}$ & $\begin{array}{l}0.7 \\
0.13 \\
0.13\end{array}$ & $\begin{array}{l}0.01 \\
0.96\end{array}$ & $\begin{array}{l}0.15 \\
0.45\end{array}$ & $\begin{array}{c}-0.10 \\
0.58\end{array}$ & $\begin{array}{l}0.76^{* * *} \\
0.00\end{array}$ & $\begin{array}{l}0.45^{* * *} \\
0.01\end{array}$ \\
\hline $\begin{array}{l}14 \text { Social sector partners } \\
\text { P-value }\end{array}$ & 5.77 & 0.90 & $\begin{array}{c}-0.09 \\
0.64\end{array}$ & $\begin{array}{c}-0.19 \\
0.27\end{array}$ & $\begin{array}{l}0.04 \\
0.83\end{array}$ & $\begin{array}{l}0.16 \\
0.41\end{array}$ & $\begin{array}{c}-0.24 \\
0.18\end{array}$ & $\begin{array}{l}0.36^{*} \\
0.04\end{array}$ & $\begin{array}{l}0.07 \\
0.71\end{array}$ & $\begin{array}{l}0.21 \\
0.32\end{array}$ & $\begin{array}{l}0.32 \\
0.10\end{array}$ & $\begin{array}{l}0.04 \\
0.82\end{array}$ & $\begin{array}{l}0.71^{* *} \\
0.00\end{array}$ & $\begin{array}{l}0.44^{* *} \\
0.01\end{array}$ \\
\hline $\begin{array}{l}15 \text { Social innovation } \\
\text { P-value }\end{array}$ & 5.73 & 1.17 & $\begin{array}{l}0.36^{*} \\
0.05\end{array}$ & $\begin{array}{l}0.44^{*} \\
0.01\end{array}$ & $\begin{array}{r}-0.01 \\
0.96\end{array}$ & $\begin{array}{l}0.37 \\
0.06\end{array}$ & $\begin{array}{l}0.00 \\
0.99\end{array}$ & $\begin{array}{l}0.11 \\
0.56\end{array}$ & $\begin{array}{r}-0.05 \\
0.78\end{array}$ & $\begin{array}{l}0.17 \\
0.44\end{array}$ & $\begin{array}{l}0.01 \\
0.96\end{array}$ & $\begin{array}{c}-0.31 \\
0.08\end{array}$ & $\begin{array}{c}-0.24 \\
0.22\end{array}$ & $\begin{array}{l}0.03 \\
0.87\end{array}$ \\
\hline 16 Earned income importance & 3.46 & 1.31 & 0.08 & 0.23 & -0.20 & 0.07 & -0.11 & -0.25 & -0.29 & -0.08 & -0.21 & -0.31 & -0.27 & 0.15 \\
\hline $\begin{array}{l}17 \text { Earned income satisfaction } \\
\text { P-value }\end{array}$ & 3.94 & 1.59 & $\begin{array}{c}0.089 \\
0.63\end{array}$ & $\begin{array}{c}-0.20 \\
-0.04 \\
0.83\end{array}$ & $\begin{array}{l}0.20 \\
0.17 \\
0.33\end{array}$ & $\begin{array}{l}0.16 \\
0.41\end{array}$ & $\begin{array}{l}0.07 \\
0.22 \\
0.21\end{array}$ & $\begin{array}{c}-0.10 \\
0.79\end{array}$ & $\begin{array}{l}0.10 \\
0.25 \\
0.15\end{array}$ & $\begin{array}{l}0.11 \\
0.11 \\
0.61\end{array}$ & $\begin{array}{l}0.27 \\
0.11 \\
0.59\end{array}$ & $\begin{array}{l}0.07 \\
0.00 \\
1.00\end{array}$ & $\begin{array}{r}-0.05 \\
0.79\end{array}$ & $\begin{array}{l}0.50 \\
0.12 \\
0.51\end{array}$ \\
\hline $\begin{array}{l}18 \text { Human capital } \\
\text { P-value }\end{array}$ & 0.72 & 0.46 & $\begin{array}{l}0.20 \\
0.32\end{array}$ & $\begin{array}{l}0.02 \\
0.90\end{array}$ & $\begin{array}{l}0.25 \\
0.20\end{array}$ & $\begin{array}{c}-0.27 \\
0.20\end{array}$ & $\begin{array}{l}0.33 \\
0.08\end{array}$ & $\begin{array}{c}-0.06 \\
0.75\end{array}$ & $\begin{array}{l}0.32 \\
0.08\end{array}$ & $\begin{array}{l}-0.44^{*} \\
0.04\end{array}$ & $\begin{array}{c}-0.05 \\
0.83\end{array}$ & $\begin{array}{l}0.15 \\
0.43\end{array}$ & $\begin{array}{c}-0.17 \\
0.38\end{array}$ & $\begin{array}{c}-0.05 \\
0.81\end{array}$ \\
\hline $\begin{array}{l}19 \text { Physical capital } \\
\text { P-value }\end{array}$ & 0.47 & 0.51 & $\begin{array}{l}-0.39^{*} \\
0.04\end{array}$ & $\begin{array}{r}-0.22 \\
0.24\end{array}$ & $\begin{array}{l}-0.48^{* *} \\
0.01\end{array}$ & $\begin{array}{c}-0.25 \\
0.23\end{array}$ & $\begin{array}{l}-0.47^{* *} \\
0.01\end{array}$ & $\begin{array}{l}-0.41^{*} \\
0.03\end{array}$ & $\begin{array}{l}-0.50^{* *} \\
0.01\end{array}$ & $\begin{array}{r}-0.25 \\
0.27\end{array}$ & $\begin{array}{r}-0.27 \\
0.20\end{array}$ & $\begin{array}{c}-0.30 \\
0.10\end{array}$ & $\begin{array}{l}0.12 \\
0.54\end{array}$ & $\begin{array}{l}0.06 \\
0.76\end{array}$ \\
\hline 20 Financial capital & 0.56 & 0.50 & 0.11 & 0.11 & 0.11 & 0.07 & 0.04 & 0.03 & 0.22 & -0.34 & -0.06 & 0.15 & 0.12 & 0.32 \\
\hline 21 Social capital & 0.69 & 0.47 & $0.41^{*}$ & 0.35 & 0.14 & 0.38 & 0.02 & $0.51^{* *}$ & 0.25 & $0.44 *$ & 0.23 & $\begin{array}{l}-0.71 \\
-0.02\end{array}$ & 0.05 & $\begin{array}{l}-0.03 \\
-0.86\end{array}$ \\
\hline $\begin{array}{l}\text { P-value } \\
22 \text { Heterogeneous resources } \\
\text { P-value }\end{array}$ & 2.44 & 0.50 & $\begin{array}{l}0.03 \\
0.25 \\
0.19\end{array}$ & $\begin{array}{l}0.05 \\
0.24 \\
0.20\end{array}$ & $\begin{array}{c}0.48 \\
-0.04 \\
0.83\end{array}$ & $\begin{array}{r}0.07 \\
-0.05 \\
0.82\end{array}$ & $\begin{array}{r}0.53 \\
-0.04 \\
0.82\end{array}$ & $\begin{array}{l}0.01 \\
0.03 \\
0.89\end{array}$ & $\begin{array}{l}0.80 \\
0.05 \\
0.81\end{array}$ & $\begin{array}{l}0.04 \\
-0.54 * \\
0.01\end{array}$ & $\begin{array}{c}0.28 \\
-0.15 \\
0.49\end{array}$ & $\begin{array}{c}0.91 \\
-0.03 \\
0.86\end{array}$ & $\begin{array}{l}0.81 \\
0.13 \\
0.52\end{array}$ & $\begin{array}{l}0.86 \\
0.31 \\
0.09\end{array}$ \\
\hline
\end{tabular}


Table 17: Correlations - Survey instrument continued

\begin{tabular}{|c|c|c|c|c|c|c|c|c|c|c|c|}
\hline & 12 & 13 & 14 & 15 & 16 & 17 & 18 & 19 & 20 & 21 & 20 \\
\hline 13 Public sector partners & $0.45^{* *}$ & 1.00 & & & & & & & & & \\
\hline P-value & 0.01 & & & & & & & & & & \\
\hline 14 Social sector partners & $0.44 * *$ & $0.47 * *$ & 1.00 & & & & & & & & \\
\hline P-value & 0.01 & 0.00 & & & & & & & & & \\
\hline 15 Social innovation & 0.03 & $-0.37^{*}$ & -0.22 & 1.00 & & & & & & & \\
\hline P-value & 0.87 & 0.03 & 0.21 & & & & & & & & \\
\hline 16 Earned income importance & 0.15 & $-0.36^{*}$ & $-0.44^{*}$ & $0.52 * *$ & 1.00 & & & & & & \\
\hline P-value & 0.38 & 0.04 & 0.01 & 0.00 & & & & & & & \\
\hline 17 Earned income satisfaction & 0.12 & 0.15 & -0.17 & 0.19 & 0.10 & 1.00 & & & & & \\
\hline P-value & 0.51 & 0.40 & 0.35 & 0.28 & 0.58 & & & & & & \\
\hline 18 Human capital & -0.05 & 0.05 & -0.07 & -0.03 & -0.12 & 0.15 & 1.00 & & & & \\
\hline P-value & 0.81 & 0.80 & 0.69 & 0.87 & 0.51 & 0.43 & & & & & \\
\hline 19 Physical capital & 0.06 & -0.13 & 0.07 & 0.05 & 0.29 & -0.11 & -0.11 & 1.00 & & & \\
\hline P-value & 0.76 & 0.48 & 0.71 & 0.78 & 0.11 & 0.55 & 0.55 & & & & \\
\hline 20 Financial capital & 0.32 & 0.21 & 0.14 & -0.13 & -0.06 & -0.08 & -0.13 & -0.31 & 1.00 & & \\
\hline P-value & 0.08 & 0.25 & 0.45 & 0.50 & 0.74 & 0.69 & 0.47 & 0.09 & & & \\
\hline $21 \overline{\text { Social capital }}$ & -0.03 & 0.02 & -0.01 & 0.04 & -0.01 & 0.10 & -0.27 & $-0.45^{*}$ & -0.19 & 1.00 & \\
\hline P-value & 0.86 & 0.90 & 0.95 & 0.83 & 0.96 & 0.61 & 0.13 & 0.01 & 0.31 & & \\
\hline 22 Heterogeneous resources & 0.31 & 0.14 & 0.13 & -0.07 & 0.11 & 0.03 & $0.41^{*}$ & 0.18 & $0.40 * *$ & 0.05 & 1.00 \\
\hline P-value & 0.09 & 0.43 & 0.48 & 0.73 & 0.54 & 0.88 & 0.02 & 0.32 & 0.00 & 0.78 & \\
\hline
\end{tabular}


Figure 3: Partnership diversity and heterogeneous resource conditions

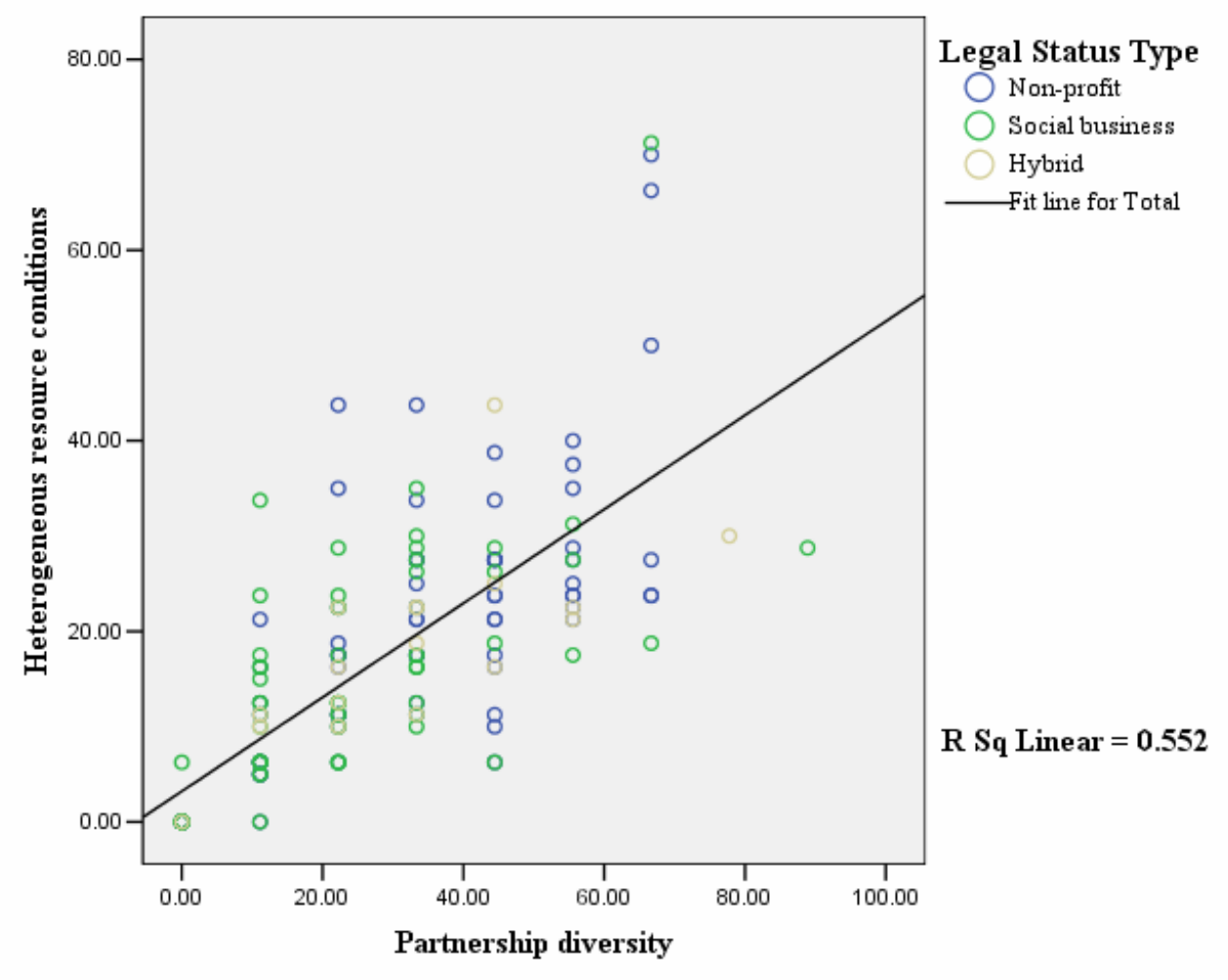

Nevertheless, a potential limitation of these findings is that the different types of capital are measured if a resource in that particular category is gained through partnerships. So if a social venture engages in a partnership with a particular type of entity, they expect to gain one type of resource through this relationship. However, the more partnership diversity of a social venture, the more different types of resources one might expect a social venture to gain through these partnerships. Thus, this method of measurement might potentially result in a strong covariance between partnerships and resources which could impact these findings. Nevertheless, a social venture could just gain one type of capital through different types of partnerships which would lead to lower heterogeneous resource conditions. The method of measurement of heterogeneous resource conditions and partnership diversity is assessed in a way to limit this potential limitation. 
Hypothesis $2 \mathrm{~b}$ is supported that heterogeneous resource conditions are positively associated with a competitive advantage. The hypothesis assesses whether ventures with different types of capital are more likely to have a competitive advantage. According to the business plan sample and the correlations in Table 16, heterogeneous resource conditions are significantly positively related to competitive advantage $\left(r=0.19^{*}, p<\right.$ $0.05)$, venture development $\left(r=0.17^{*}, \mathrm{p}<0.05\right)$, and social value $\left(r=0.24^{* *}, p<0.01\right)$. This suggests that the greater the variety of different types of capital resources, the more the competitive advantage, especially in terms of venture development and potential for social value creation. Both competitive advantage and venture development are most strongly correlated with human capital $\left(r=0.16^{*}, p<0.05 ; r=0.17^{*}, p<0.05\right.$ respectively) and social capital ( $r=0.21^{* *}, p<0.01 ; r=0.20^{* * ;} p<0.01$ respectively), while the relationships with financial and physical capital are weak and not significant. Social value is also strongly significantly related to social capital resources $\left(r=0.24^{* *}, p\right.$ $<0.01)$. This suggests that human capital and social capital resources gained through partnerships are related to a competitive advantage in terms of the achievement of venture development activities and social value creation.

The exploratory survey data provides some additional insight into Hypothesis $2 \mathrm{~b}$. As seen in the correlations in Table 17, the only significant relationship is between heterogeneous resource conditions and environmental value, but the relationship is negative $\left(r=-0.54^{*}, p<0.05\right)$. The independent sample t-test is significant $(F=0.50, p$ $<0.05$ ), but due to the small sample size of 22 social ventures for this relationship, the $F$ is very small, and the results should be viewed as exploratory. Social ventures with more 
heterogeneous resource conditions show less emphasis on environmental value creation. Environmental value benefits the environment through recyclable products, eco-friendly products/services or policies that promote recycling, energy savings, and reduction in greenhouse gas emissions. These findings suggest that the more different types of resources gained through partnerships, the less likely the venture will create environmental value. Environmental value has a significant negative relationship with human capital $\left(r=-0.44^{*}, p<0.05\right)$. Future research can examine this negative relationship in greater detail through interviews or additional survey questions.

Another interesting finding when assessing the individual components of heterogeneous resource conditions in the survey data is that physical capital has significant negative relationships with several different components of competitive advantage: competitive advantage $\left(r=-0.39^{*}, p<0.05\right)$, value creation $\left(r=-0.48^{* *}, p<0.01\right)$, economic value $\left(r=-0.47^{* *}, p<0.01\right)$, and social value $\left(r=-0.50^{* *}, p<0.01\right)$. In addition, social capital in both the survey and business plan samples has positive significant relationships with competitive advantage ( $r=0.41^{*}, p<0.05$ and $r=0.21^{* *}, p<0.01$ respectively), and social value ( $r=0.51^{* *}, p<0.01$ and $\left.r=0.24^{* *}, p<0.01\right)$. These findings suggest that social capital is extremely important to the attainment of a competitive advantage for a social venture, especially in terms of the creation of social value. Social capital provides access to markets, networks, and beneficiaries that can facilitate the creation of social value. 
Finally, the relationship between heterogeneous resource conditions in the business plan and the likelihood of launching as per the survey are assessed. Using the non-parametric Mann-Whitney t-test, the significant findings suggest that ventures that launch have greater heterogeneous conditions (Mean $=42.28)$, than those that to not launch (Mean $=$ 32.37, $p<0.05$ ). These significant results support the business plan sample findings regarding the relationship between heterogeneous resource conditions and a competitive advantage.

Hypothesis $2 \mathrm{c}$ is supported that partnership diversity is positively associated with a competitive advantage. The hypothesis assesses the direct relationship between a variety of different types of partnerships and the competitive advantage of a social venture. The business plan sample suggests that many of the relationships between partnership diversity and competitive advantage are significant and positive. As seen in the correlations in Table 16, partnership diversity is significantly positively related to competitive advantage $\left(r=0.31^{* *} ; p<0.01\right)$, venture development $\left(r=0.27^{* *} ; p<0.01\right)$, value creation $\left(r=0.19^{*}, p<0.05\right)$, economic value $\left(r=0.20^{* *}, p<0.01\right)$, and social value $\left(r=0.27^{* *}, p<0.01\right)$.

At the same time, all of the different types of private, public, and social sector partners are significantly positively related to competitive advantage, venture development, and social value. Almost all of these relationships are significant at the $p<0.01$ level. Both private sector and public sector partners are also significantly positively related to value 
creation ( $r=0.15^{*}, p<0.05$ and $r=0.17^{*}, p<0.05$ respectively), while social sector partners is also positively significantly related to economic value $\left(r=0.21^{* *}, p<0.01\right)$.

The exploratory survey results provide additional insight into Hypothesis 2c. Using the survey data, as seen in the correlations in Table 17, only social sector partners is positively significantly related to social value ( $r=0.36^{*}, p<0.05$ ), which is similar to the business plan findings. The discrepancies with the business plan data can be due to the fact that the potential for competitive advantage discussed in the business plans is different from that actually achieved as per the follow-up survey. In addition, the business plan data is coded by an independent rater, while the survey is answered by a member of the social venture management team who might or might not be the same person who wrote the business plan.

Finally, the relationship between partnership diversity in the business plans and the likelihood of launch as per the survey are assessed using t-tests. The findings suggest a significant relationship between launching and partnership diversity $(p<0.05)$. Those social ventures that have greater partnership diversity are more likely to launch. A broad range of partners facilitates access to resources and potentially the ability for a social venture to launch.

Hypothesis $2 \mathrm{~d}$ is not supported that resource conditions mediate the relationship between partnership diversity and a competitive advantage. The mediation model hypothesizes that partnership diversity causes heterogeneous resource conditions which in turn causes 
a competitive advantage. This relationship is tested using the business plan data in a multiple regression as shown in Table 18. The results suggest a significant positive relationship between partnership diversity and the dependent variable competitive advantage. However when the variable heterogeneous resource conditions is added to the regression models, heterogeneous resource conditions is not significant due to its high correlation with partnership diversity. Thus heterogeneous resource conditions do not mediate this relationship, but a direct relationship between partnership diversity and the achievement of a competitive advantage exists.

\section{Table 18: Multiple regression results}

\begin{tabular}{|c|c|c|c|c|c|c|c|c|c|}
\hline & $d f$ & Model 1 & Model 2 & Model 3 & Model 4 & Model 5 & Model 6 & Model 7 & Model 8 \\
\hline Partnership diversity & 1 & $0.16^{* *}$ & $0.20 * *$ & & $0.13 * *$ & $0.17 * *$ & & $0.07 *$ & 0.09 \\
\hline Resource conditions & 1 & & -0.08 & & & -0.08 & & & -0.04 \\
\hline Start up experience & 1 & & & $1.63 * *$ & $1.25^{*}$ & $1.32 *$ & $1.42 *$ & $1.28 *$ & $1.31 *$ \\
\hline Business plan completeness & 1 & & & $2.60 * *$ & $2.47 * *$ & $2.43 * *$ & $2.13 * *$ & $2.10 * *$ & $2.10 * *$ \\
\hline Business sponsor & 8 & & & & & & & 2.05 & 1.81 \\
\hline SPU vs. UT Austin & & & & & & & $-4.71 * *$ & $-4.22 *$ & $-4.04 *$ \\
\hline Washington vs. UT Austin & & & & & & & $20.40 * *$ & $19.05 * *$ & $19.44 * *$ \\
\hline WJF vs. Austin & & & & & & & $23.81 * *$ & $21.20 * *$ & $20.74 * *$ \\
\hline Social venture type & 2 & & & & & & & & \\
\hline Hybrid vs. Nonprofit & & & & & & & $5.62 *$ & $5.44 *$ & $5.36^{*}$ \\
\hline Forprofit vs. Nonprofit & & & & & & & 1.03 & 1.45 & 1.40 \\
\hline Client location & 4 & & & & & & & & \\
\hline Global vs. U.S. & & & & & & & $5.91 *$ & $5.94 *$ & $6.13 *$ \\
\hline Constant & & 11.11 & 11.37 & 2.14 & -0.40 & 0.01 & 3.84 & 2.00 & 2.06 \\
\hline $\mathrm{F}$ & & $18.92 * *$ & $9.90 * *$ & $19.26^{* *}$ & $13.09^{*}$ & $13.82 * *$ & $7.31 * *$ & $7.24 * *$ & $6.82 * *$ \\
\hline R Squared & & 0.10 & 0.10 & 0.18 & 0.24 & 0.24 & 0.42 & 0.43 & 0.43 \\
\hline Adjusted R Squared & & 0.09 & 0.09 & 0.17 & 0.22 & 0.22 & 0.36 & 0.37 & 0.37 \\
\hline
\end{tabular}

When control variables are added to the model, the results for Hypothesis $2 \mathrm{~d}$ are similar. Partnership diversity has a direct effect on competitive advantage, but heterogeneous resource conditions do not improve the model and are not significant, thus they do not mediate the relationship. The inclusion of the control variables in the model also 
improves the adjusted R squared from 0.09 in Model 2 to 0.37 as seen in Model 8. These results suggest that these control variables and partnership diversity explain up to $37 \%$ of the variation in the competitive advantage of nascent social ventures.

Adding control variables to the model also suggests the importance of different characteristics of the social venture, including social venture type, client location, and start-up experience, to attaining a competitive advantage. Hybrid social ventures are significantly more likely to have a competitive advantage over nonprofit social ventures. As discussed earlier, this could be due to the fact that hybrid social ventures are able to take advantage of the benefits of operating with both for-profit and nonprofit legal structures. The results also suggest that social ventures with clients or beneficiaries located in multiple global locations are likely to have more of a competitive advantage than social ventures with clients or beneficiaries located solely in the United States. This could be due to the diversification of risk, or the greater ease of creating value or being successful if operating in multiple locations. Finally, a social venture with founders or management that has started previous ventures has a greater chance of success and creating value and developing the venture. This finding is supported by prior research on entrepreneurial ventures.

The control variables also suggest that different components of the business plan and the corresponding competition impact competitive advantage. Business plan completeness suggests that the more complete a business plan, or the more principal sections the business plan includes, the greater the competitive advantage. Business plan 
completeness reflects a measure of quality and sophistication and is significantly related to a competitive advantage. Finally, the business plan sponsor potentially impacts competitive advantage. The variable business plan sponsor is significant for three of the sponsors when compared to the reference group UT Austin. UT Austin is chosen as the reference category since $57 \%$ of the business plans come from this competition. Social ventures participating in competitions at Seattle Pacific University have a significantly lower competitive advantage than those participating at the UT Austin competition. At the same time, nascent social ventures participating at the competition at the University of Washington and the William James Foundation (WJF) have a significantly higher competitive advantage than those participating at the competition at UT Austin. Thus social ventures participating in competitions at the University of Washington and WJF create more value and result in more development than nascent social ventures emerging from UT Austin. UT Austin might want to assess what these competitions are doing better so that they might improve their own competition.

Hypothesis $3 \mathrm{a}$ is also supported that partnership diversity is positively related to social innovation. This hypothesis assesses whether a greater variety of different types of partnerships is related to social innovation. As seen in the correlations in Table 16, partnership diversity is significantly positively related to social innovation $\left(r=0.25^{* *}, p\right.$ $<0.01$ ) using the business plan sample. In fact, social innovation is positively significantly related to private sector partners $\left(r=0.26^{* *}, p<0.01\right)$ and public sector partners $\left(r=0.22^{* *}, p<0.01\right)$ and marginally significantly related with social sector partners $(r=0.14, p=0.07)$. The exploratory survey results only found a significant 
relationship between public sector partners and social innovation $\left(r=-0.37^{*}, p<0.05, n\right.$ $=33$ ), as seen in Table 17, but the relationship is negative. Nevertheless, the survey results are merely exploratory given the small sample size. Future research can further examine the nature of the relationship between social innovation and partnership diversity. Are more different types of partnerships positively or negatively affecting social innovation? Perhaps this varies at different stages in a social venture life cycle.

Hypothesis $3 \mathrm{~b}$ is partially supported that partnership diversity is positively related to earned income. According to the business plan data and the correlations in Table 16, partnership diversity is marginally significant and positively related to earned income streams $(r=0.14, p=0.06)$. Thus the more different types of partners a social venture has the greater the likelihood that the social venture has more types of products of services that produce earned income. Perhaps different types of partners help develop or support these different earned income revenue streams.

Nevertheless, partnership diversity is negatively related to earned income importance in the business plan sample $\left(r=-0.20^{* *}, p<0.01\right)$. In the survey data this relationship was also negative, but not significant $(r=-0.27, p=0.14, n=27$ ), as seen in the correlations in Table 17. However, in both the business plan and survey samples this relationship with earned income importance is especially strong for the social sector partners $(r=$ $0.15^{*}, p<0.05$ and $r=-0.44^{*}, p<0.05$ respectively) and public sector partners ( $r=-$ $0.28^{* *}, p<0.01$ and $r=-0.36^{* *}, p<0.05$ respectively). This suggests that as the number of different partners increases the importance of earned income decreases. A social 
venture that has a greater diversity of partnerships is probably able to attain more different types of resources, and thus is less dependent on earned income, than social ventures that have a less diverse array of partnerships. At the same time this could suggest that the more important earned income, the less important public and social sector partners, as there is less need to gain additional resources from these partners.

Hypothesis $3 \mathrm{c}$ is supported that social venture innovation and earned income are positively related to a competitive advantage. As seen in the correlations in Table 16, the business plan data shows that social innovation is significantly positively related to a competitive advantage $\left(r=0.30^{* *}, p<0.01\right)$ and venture development $\left(r=0.38^{* *}, p<\right.$ 0.01). The exploratory survey data also suggests that social innovation is significantly positively related to venture development $\left(r=0.44^{*}, p<0.05\right)$ and competitive advantage $\left(r=0.36^{* *}, p<0.05\right)$ as seen in the correlations in Table 17 . These findings suggest that social innovation is most likely to lead to venture development rather than the actual creation of value. At the same time, t-tests suggest that more innovative ventures are more likely to launch $(p<0.05, n=72)$. Innovative services and strategies facilitate the launching of a venture. A social venture that has innovative technology, enters new markets, and has innovative business models (the components of social innovation) might be more likely to launch the venture as they are more likely to appeal to consumers and potential funders and develop more efficient business models.

The findings from the business plan sample also suggest that earned income streams is positively significantly related to competitive advantage $\left(r=0.19^{*}, p<0.05\right)$ and venture 
development $\left(r=0.18^{*}, p<0.05\right)$ as seen in the correlations in Table 16. In addition, as the number of types of earned income streams increases, ventures are more likely to launch $(p<0.05, n=72)$. These findings suggest as the number of earned income streams increases; a social venture is more likely to attain a competitive advantage which intuitively makes sense as more diverse revenue streams are available. At the same time, if a social venture has various earned income streams, they might believe they can better meet the costs of starting up. Ultimately, this increases the likelihood the social venture will launch.

Earned income importance is significantly positively related to value creation $(r=$ $0.20 * *, p<0.05)$, economic value $(r=0.22 * *, p<0.01)$, and environmental value $(r=$ $\left.0.16^{*}, p<0.05\right)$ in the business plan data as seen in the correlations in Table 16. Thus as social ventures become more reliant on earned income they create more value. As discussed early, different products or services that earn income might also directly benefit individuals and create value. For example, a social venture that sells handicrafts designed by local artisans employs these individuals, provides them with a source of income, and also earns a type of revenue stream in this endeavor.

\section{Discussion}

The goal of this dissertation is to provide greater insight into the question: How do nascent social ventures develop a competitive advantage? More specifically, this dissertation focuses on better understanding how partnerships lead to a competitive advantage by applying the RBV theoretical framework to the context of nascent social 
ventures. According to the RBV, those nascent social ventures that develop heterogeneous resource conditions will develop a competitive advantage. A diverse range of partnerships with distinct types of organizational entities provide a means to gain different human, social, financial, and physical capital resources. At the same time, through partnerships social ventures acquire resources and capabilities that facilitate the development and implementation of earned income and social innovation strategies. Thus, this research posits that partnerships lead to a competitive advantage for nascent social ventures.

Two complementary samples of nascent social ventures provide a means to examine the relationship between partnership diversity, strategy, heterogeneous resource conditions, and a competitive advantage. The business plan sample provides the basis for assessing the hypotheses, and the exploratory survey provides some additional insight especially into the factors that facilitate the launch of the social venture. The results suggest that indeed an important relationship exists between the development of partnerships with numerous different types of entities and a competitive advantage for nascent social ventures. In addition, there is an important relationship between partnership diversity, social innovation and earned income strategies, and a competitive advantage.

Overall, several important findings merit further discussion and these are summarized in Table 19. First, partnerships are important for the achievement of social venture goals. Second, hybrids generally have a significantly greater competitive advantage than forprofit and nonprofit social ventures. Third, partnership diversity is significantly correlated 


\section{Table 19: Key findings summary}

\begin{tabular}{|c|c|c|c|}
\hline Finding & Implication & Support & Caveat \\
\hline $\begin{array}{l}1 \text { Partnership important } \\
\text { for social ventures }\end{array}$ & $\begin{array}{l}\text { Partnership importance much } \\
\text { less emphasized in business } \\
\text { plan Executive Summary than } \\
\text { by survey respondents. }\end{array}$ & $\begin{array}{l}\text { Both } \\
\text { samples }\end{array}$ & \\
\hline $\begin{array}{l}2 \text { Hybrids have a } \\
\text { significantly greater } \\
\text { competitive advantage } \\
\text { than for-profit and } \\
\text { nonprofit social ventures }\end{array}$ & $\begin{array}{l}\text { Hybrid ventures are able to } \\
\text { take advantage of the benefits } \\
\text { of both for-profit and } \\
\text { nonprofit legal structures. }\end{array}$ & $\begin{array}{l}\text { Business } \\
\text { plan sample }\end{array}$ & $\begin{array}{l}\text { Only } 17 \text { hybrid social } \\
\text { ventures in business } \\
\text { plan sample }\end{array}$ \\
\hline $\begin{array}{l}3 \text { Partnership diversity } \\
\text { and heterogeneous } \\
\text { resource conditions } \\
\text { strongly significantly } \\
\text { related }\end{array}$ & $\begin{array}{l}\text { All different types of } \\
\text { partnerships and overall } \\
\text { partnership diversity provide a } \\
\text { means to attain all types of } \\
\text { resources and heterogeneous } \\
\text { resource conditions. }\end{array}$ & $\begin{array}{l}\text { Business } \\
\text { plan sample }\end{array}$ & $\begin{array}{l}\text { Strong correlations } \\
\text { might be due to } \\
\text { measurement methods } \\
\text { of partnerships and } \\
\text { resources gained } \\
\text { through partnerships }\end{array}$ \\
\hline $\begin{array}{l}\text { Partnership diversity and } \\
\text { competitive advantage } \\
\text { (especially with venture } \\
\text { development and value } \\
\text { creation - } \\
\text { social/economic) } \\
\text { significantly related }\end{array}$ & $\begin{array}{l}\text { Partnerships with a more } \\
\text { diverse range of entities } \\
\text { facilitates the development of } \\
\text { activities and the creation of } \\
\text { value as working together to } \\
\text { reach these goals. }\end{array}$ & $\begin{array}{l}\text { Business } \\
\text { plan sample }\end{array}$ & \\
\hline $\begin{array}{l}\text { Start-up experience, } \\
\text { client location, and } \\
\text { business plan } \\
\text { completeness } \\
\text { significantly important in } \\
\text { relationship between } \\
\text { partnership diversity and } \\
\text { competitive advantage }\end{array}$ & $\begin{array}{l}\text { Social ventures with } \\
\text { management with previous } \\
\text { start-up experience, a more } \\
\text { complete business plan, and } \\
\text { global operations are more } \\
\text { likely to succeed }\end{array}$ & $\begin{array}{l}\text { Business } \\
\text { plan sample }\end{array}$ & \\
\hline $\begin{array}{l}\text { Partnership diversity } \\
\text { significantly related to } \\
\text { launch }\end{array}$ & $\begin{array}{l}\text { Social ventures with greater } \\
\text { partnership diversity are more } \\
\text { likely to launch. }\end{array}$ & $\begin{array}{l}\text { Combine } \\
\text { samples }\end{array}$ & \\
\hline
\end{tabular}


Table 19: Key findings summary continued

\begin{tabular}{|c|c|c|c|}
\hline Finding & Implication & Support & Caveat \\
\hline $\begin{array}{l}4 \text { Heterogeneous } \\
\text { resource conditions } \\
\text { and competitive } \\
\text { advantage significantly } \\
\text { related }\end{array}$ & $\begin{array}{l}\text { Social ventures that are able } \\
\text { to gain a more diverse set of } \\
\text { resources through } \\
\text { partnerships can create more } \\
\text { social value. }\end{array}$ & $\begin{array}{l}\text { Business } \\
\text { plan sample }\end{array}$ & \\
\hline $\begin{array}{l}\text { Social capital is } \\
\text { significantly important to } \\
\text { the development of a } \\
\text { competitive advantage } \\
\text { and the creation of social } \\
\text { value. }\end{array}$ & $\begin{array}{l}\text { Social capital provides access } \\
\text { to markets, networks, and } \\
\text { beneficiaries that can } \\
\text { facilitate the creation of social } \\
\text { value. }\end{array}$ & $\begin{array}{l}\text { Both } \\
\text { samples }\end{array}$ & \\
\hline $\begin{array}{l}\text { Social ventures with } \\
\text { more heterogeneous } \\
\text { resources, significantly } \\
\text { more likely to launch }\end{array}$ & $\begin{array}{l}\text { Heterogeneous resource } \\
\text { conditions faciliate the ability } \\
\text { to launch. }\end{array}$ & $\begin{array}{l}\text { Combine } \\
\text { samples }\end{array}$ & \\
\hline $\begin{array}{l}5 \text { Social innovation and } \\
\text { partnership diversity } \\
\text { significantly related }\end{array}$ & $\begin{array}{l}\text { Greater partnership diversity } \\
\text { assists in innovation of social } \\
\text { venture. }\end{array}$ & $\begin{array}{l}\text { Business } \\
\text { plan sample }\end{array}$ & \\
\hline $\begin{array}{l}\text { Social innovation is most } \\
\text { significantly related to } \\
\text { the venture development } \\
\text { component of a } \\
\text { competitive advantage }\end{array}$ & $\begin{array}{l}\text { Nascent social ventures that } \\
\text { develop more innovative } \\
\text { strategies are more likely to } \\
\text { develop capabilities or } \\
\text { activities that help them grow } \\
\text { as a venture. }\end{array}$ & $\begin{array}{l}\text { Both } \\
\text { samples }\end{array}$ & \\
\hline $\begin{array}{l}\text { More innovative } \\
\text { ventures significantly } \\
\text { more likely to launch }\end{array}$ & $\begin{array}{l}\text { Innovative services and } \\
\text { strategies faciliates the } \\
\text { launching of a venture. }\end{array}$ & $\begin{array}{l}\text { Combine } \\
\text { samples }\end{array}$ & \\
\hline $\begin{array}{l}6 \text { Earned income streams } \\
\text { is marginally } \\
\text { significantly related to } \\
\text { partnership diversity }\end{array}$ & $\begin{array}{l}\text { Partners assist social ventures } \\
\text { in their development or } \\
\text { maintenance of different } \\
\text { revenue streams. }\end{array}$ & $\begin{array}{l}\text { Business } \\
\text { plan sample }\end{array}$ & $\begin{array}{l}\text { Number of earned } \\
\text { income streams not } \\
\text { measured in survey } \\
\text { sample }\end{array}$ \\
\hline $\begin{array}{l}\text { Earned income } \\
\text { importance is negatively } \\
\text { related to partnership } \\
\text { diversity }\end{array}$ & $\begin{array}{l}\text { More partnerships with } \\
\text { different types of entities } \\
\text { creates less dependence on } \\
\text { earned income as social } \\
\text { ventures gain other resources } \\
\text { from partnerships. }\end{array}$ & $\begin{array}{l}\text { Both } \\
\text { samples }\end{array}$ & \\
\hline $\begin{array}{l}\text { Earned income streams } \\
\text { is significantly related to } \\
\text { venture development and } \\
\text { launching }\end{array}$ & $\begin{array}{l}\text { The more earned income } \\
\text { streams a venture has the } \\
\text { more resources it has to } \\
\text { develop as a venture and } \\
\text { launch. }\end{array}$ & $\begin{array}{l}\text { Business } \\
\text { plan sample }\end{array}$ & $\begin{array}{l}\text { Number of earned } \\
\text { income streams not } \\
\text { measured in survey } \\
\text { sample }\end{array}$ \\
\hline $\begin{array}{l}\text { Earned income } \\
\text { importance is strongly } \\
\text { related to value creation } \\
\text { (especially economic and } \\
\text { environmental value) }\end{array}$ & $\begin{array}{l}\text { More resources to create } \\
\text { value }\end{array}$ & $\begin{array}{l}\text { Business } \\
\text { plan sample }\end{array}$ & \\
\hline
\end{tabular}


with heterogeneous resource conditions and a competitive advantage. Fourth, heterogeneous resource conditions are significantly related to a competitive advantage. Fifth, partnership diversity and social innovation strategies are significantly related. Social innovation is significantly correlated to a competitive advantage. Finally, partnership diversity affects earned income strategies differently, and earned income is significantly related to a competitive advantage. Together, these findings provide support that the RBV framework is appropriate to apply to the context of nascent social ventures. Each of these findings and their implications are discussed in detail below.

The results of Hypothesis la suggest that partnerships are much more important in the survey sample than in the business plan sample. This could be because partnerships are less emphasized in the Executive Summary of a business plan than by survey respondents. Nevertheless, the business plan results are not significant across social venture type. Although the survey sample significantly suggests that partnerships are most important for social ventures that are structured as nonprofit legal entities, the sample size is very small. Partnerships provide a means for social ventures to fill resource gaps and develop adequate resource conditions. Nonprofit social ventures are more likely to turn to external sources for resources since they are more dependent on other entities to develop sufficient capital. For-profit social ventures have less access to grants and must develop more of their financial capital internally. Thus for-profit social ventures are less likely to turn to partnerships. For hybrid ventures the importance of a partnership might vary according to the degree of hybridness of a social venture. Some hybrid social ventures might focus more on developing economic value, while others 
focus more on social value. Thus, perhaps hybrid social ventures that emphasize their nonprofit focus will place more emphasis on partnerships than hybrids that emphasize their for-profit component. These findings can be examined further in future research.

Hypothesis $1 \mathrm{~b}$ suggests that hybrid social ventures have a greater competitive advantage than for-profit and nonprofit social ventures. This could be because hybrid ventures are able to take advantage of the benefits of both for-profit and nonprofit legal structures. Perhaps the for-profit arm of a hybrid venture focuses on economic value creation, while the nonprofit arm develops initiatives that create social value. Thus a hybrid social venture with both a nonprofit and for-profit component might develop more value than a social venture with only a nonprofit or for-profit entity.

Third, Hypotheses $2 \mathrm{a}$ and $2 \mathrm{c}$ are strongly significantly supported that partnership diversity is highly correlated with heterogeneous resource conditions and a competitive advantage. The results suggest that public, private, and social sector partners are all significantly positively related to both heterogeneous resource conditions and different types of human, social, financial, and physical capital. Thus, a diverse range of partnerships provide a means to gain all types of resources and heterogeneous resource conditions.

The findings also suggest a strong significant relationship between partnership diversity and a competitive advantage. This relationship is especially strong with venture development and value creation (particularly economic and social value). Partnerships 
with a more diverse range of entities might facilitate the development or implementation of activities like building websites, creating prototypes or contracting professional services. At the same time, partnerships with a greater number of different types of entities can facilitate the ability to launch. If a venture launches, it is more likely to create value. Thus partnerships with a variety of likeminded entities interested in creating value can impact intended beneficiaries by creating greater social or economic benefits.

Management or founder team start-up experience, client location, and business plan completeness are important control variables in explaining the relationship between partnership diversity and a competitive advantage. Social ventures with a more experienced management or founder team are more able to apply knowledge from their previous ventures to the success of the social venture. This trend is seen throughout general entrepreneurship research. At the same time, social ventures with operations in different global locations create more of a competitive advantage than social ventures solely operating in the United States. This might be due to the fact that these social ventures can diversity risk, or simply because by operating in more locations, they can create more value. At the same time, social ventures with a more complete business plan show a greater degree of sophistication, quality, and dedication to the growth of the social venture which impacts competitive advantage. Social venture management that demonstrates the ability to develop a sophisticated business plan, probably also has the tools and knowledge to develop the venture and create more value. 
Fourth, the results suggest that heterogeneous resource conditions are significantly related to a competitive advantage (Hypothesis 2 b), especially to social value. This suggests that social ventures that are able to gain a more diverse set of resources through partnerships can create more social value. Social capital resources are particularly important in the development of a competitive advantage. Social capital provides access to other resources, like markets, networks, or beneficiaries, and facilitates the development of social value.

Fifth, partnership diversity and social innovation strategies are significantly related. The results suggest that greater partnership diversity is more likely to lead to social innovation. Partnerships with different types of entities can help a venture develop different types of knowledge or resources that leads to the development or implementation of innovative strategies, services, or technologies. Partners might work together to more effectively serve a population or intended beneficiary or client in an innovative way by appealing to a new market, providing a service or produce in a new way, or using a new technology.

Social innovation is most related to the venture development component of a competitive advantage. This suggests that nascent social ventures that develop more innovative strategies are likely to develop capabilities or activities that help them grow as a venture. At the same time, innovative ventures are more likely to launch. Innovative strategies are more likely to attract potential funders. At the same time, they might have more appeal to the market or be able to diffuse more rapidly through the use of innovative technology. 
Thus these innovative strategies contribute to the growth and development of a nascent social venture.

Finally, partnership diversity affects earned income strategies differently depending on which component of earned income is being measured. Although greater partnership diversity is related to more types of earned income streams, as there are more types of partners, earned income importance decreases as evidenced in both samples. This suggests that nascent social ventures that have more different types of partners will develop more earned income streams. This could be because partners assist social ventures with the development, implementation, and maintenance of these different revenue streams. However, partnership diversity might be negatively related to earned income importance, as the more partnerships with different types of entities a venture has, the less dependent they are on earned income as they gain other resources from partnerships. Thus, earned income becomes less important when social ventures have more different types of partners. Alternatively, if a social venture is able to produce all their own income and does not have to rely on other sources for revenue, then they might have less of a need for partners.

Earned income is also related to different elements of a competitive advantage. The number of earned income streams is significantly related to venture development and launching, while earned income importance is significantly related to value creation, especially economic and environmental value creation. The more earned income streams a venture has, the more likely it will be able to develop as a venture and launch as it will 
have access to resources from the sale of different products or services. At the same time, if earned income is more important, then social ventures can develop more economic and environmental value as they will have more resources to do so.

Overall, the findings provide important insight into nascent social ventures and provide support for the application of the RBV to the context of social ventures. Partnerships lead to the development of heterogeneous resource conditions and strategies that facilitate the development of a competitive advantage. 


\section{CHAPTER 6: CONCLUSION}

This dissertation seeks to answer the question how do partnerships lead to a competitive advantage in the context of social ventures? By systematically applying the RBV framework to nascent social ventures, relationships between partnerships, heterogeneous resource conditions, strategies, and a competitive advantage are examined. As a result, this dissertation is the first to systematically apply RBV to the context of social ventures and empirically examine these relationships with two complementary samples.

This final chapter explores the contributions of this dissertation, the implications for scholarly research and practitioners, opportunities for future research, and limitations of this study.

\section{Contributions}

This dissertation makes several contributions to the literature. First, this is the first study to systematically apply and empirically test the RBV in the context of social ventures. Second, the results suggest that partnerships and partnership diversity are important to the development of heterogeneous resource conditions and a competitive advantage. Third, partnerships and partnership diversity are related to earned income and social innovation strategies which are important to a competitive advantage. Fourth, a social venture's legal structure might influence this relationship. Fifth, this study provides insight into the firm creation process and launching of nascent social ventures. Finally, an innovative dataset 
is created that can be used to analyze other research questions in the context of social ventures. These contributions are discussed in detail below.

This is one of the earliest studies to systematically apply and empirically test the RBV in the context of social ventures. Until now, the RBV has primarily been used as a means to individually examine the different inputs, processes, and outputs of social ventures, but not the model as a complete framework. This dissertation builds off a conceptual model in which Teng (2007) systematically applies the RBV to commercial ventures to better understand the relationship between strategic alliances, corporate entrepreneurship strategies, resource conditions, and a competitive advantage. Nevertheless, given the different ultimate focus of social ventures, one might expect these relationships to differ. However, this dissertation empirically shows that these components are also important to the achievement of a competitive advantage for nascent social ventures.

In general, the social venture literature has been less theory driven (Short et al., 2009). Most studies that do apply theory in this context use resource dependency (Pfeffer \& Salancik, 1978) or transaction cost theory (Williamson, 1985) to better understand nonprofit ventures (Arsenault, 1998; Foster \& Meinhard, 2002; Gray, 1989; Guo \& Acar, 2005; Provan \& Milward, 1995). Resource dependency proposes that partnerships provide a means to manage external dependencies and uncertainties in their resource environment, whereas transaction cost theory focuses on partnerships as a means to reduce transaction costs (Hennart, 1988; Williamson, 1991) and maximize economic or psychological benefits (Foster \& Meinhard, 2002; Sharfman, Gray, \& Yan, 1991). 
Although some studies have used the resource based view to examine social ventures, the results are less systematic (Kistruck, 2008; Meyskens et al, 2010; Meyskens et al., Forthcoming, Seelos \& Marti, 2007).

Yet since social ventures are legally structured as nonprofit, for-profit or hybrid ventures their modus operandi may vary. The findings suggest that RBV is an appropriate framework to better understand how heterogeneous resource conditions and strategies are related to the achievement of a competitive advantage for nascent social ventures. This dissertation particularly explores the importance of partnerships and partnership diversity in this framework.

Second, the results suggest that partnerships and partnership diversity are important to the development of heterogeneous resource conditions and the development of a competitive advantage for nascent social ventures. Most existing management research on partnerships explores the role of strategic alliances in international business or for large corporations whose primary goal is improving the economic bottom line. The research on ventures interested in creating social value generally focuses on non-profit ventures and their partnerships with a single corporate or government entity or in a tri-sector partnership through case studies or anecdotes. Entrepreneurship research in this area examines the networks as a whole and how they impact entrepreneurial ventures. This dissertation examines the importance of partnerships and a diverse array of partnerships for social ventures. Partnership diversity refers to social venture partnerships with a variety of different types of partners including social ventures, religious entities, 
corporations, government, individuals, the community, financial institutions, schools, and universities. Thus, this dissertation focuses on better understanding the multiply embedded partnership framework in which social ventures actually operate with numerous partners from different sectors.

The findings suggest that greater partnership diversity facilitates the achievement of heterogeneous resource conditions, the development of strategic capabilities, the creation of value, and the development and launch of nascent social ventures. Thus, for nascent social ventures it is important to have partnerships with different types of organizational entities as this variety enables nascent social ventures to develop more activities and ultimately launch and create more different types of value. Each type of partner brings different resources and capabilities to a social venture partnership that strengthens this relationship and ultimately impacts social venture success. Social capital is particularly important for the achievement of a competitive advantage as it provides access to additional resources, markets, and beneficiaries. At the same time, founder previous start-up experience and business plan completeness are important to achieving a competitive advantage as they represent additional knowledge, sophistication, and dedication to the venture.

Third, partnership diversity is related to the development and implementation of social innovation and earned income strategies which are associated with a competitive advantage. A positive relationship between partnership diversity and social innovation suggests that when a business plan is written, social ventures envision socially innovative 
strategies. When a social venture has a greater number of different types of partners, potentially they get more ideas and assistance in developing or implementing socially innovative strategies.

Social innovation is positively related to the competitive advantage of nascent social ventures. Social ventures that use technology, enter new markets, or implement unique business models or strategies can create more value and are more likely to develop. Thus, more innovative nascent social ventures are more likely to undertake activities that help them develop or build a successful venture.

Partnership diversity is also found to be significantly positively related to a greater number of earned income streams. Nascent social ventures that have a variety of partners with different types of organizational entities have more assistance and support in developing, implementing, and maintaining more services and products that generate revenue. At the same time, the inverse relationship holds true. The development of more products and services might necessitate more partnerships to facilitate reaching new markets, communicating with different communities, and achieving venture goals. However as earned income becomes the sole source of revenue, social ventures become less dependent on a broad range of partnerships. As social ventures become more independent financially, they might need partnerships less.

A greater number of earned income streams also facilitate venture development. However, if nascent social ventures are completely dependent on their earned income as 
the only source of revenue, they are less likely to have partnerships with different types of entities. Since these social ventures are developing these resources internally, there is less need for these partnerships. Earned income importance is also related to value creation, especially economic and environmental value. Thus, social ventures that place more importance on earned income ultimately strive to create more value as suggested by the business plan sample.

Fourth, hybrid ventures have a greater competitive advantage than for-profit and nonprofit social ventures. This finding may result due to the degree of hybridness of the venture. Some hybrid social ventures might operate with more of an economic focus in order to achieve their social goals, while others might employ more of a social focus. At the same time, hybrid ventures are able to take advantage of the benefits of both forprofit and nonprofit legal structures that also facilitate the achievement of a competitive advantage. Future research can further examine the reasoning for these findings.

Fifth, this study provides insight into the firm creation process and launching of nascent social ventures. Similar to commercial ventures, partnerships appear to be an important source for nascent social ventures to attain resources and build strategic capabilities to develop a competitive advantage. Nascent social ventures develop many different activities (develop website, hire employees, incorporate, etc.) just as traditional commercial ventures do. At the same time social ventures with greater partnership diversity, and more heterogeneous resource conditions are more likely to launch. 
In addition, social capital, founder start-up experience, and business plan completeness is important to the achievement of a competitive advantage for nascent social ventures. Strategies that focus on innovation and developing earned income streams are also related to venture development and the creation of value. At the same time social innovation facilitates the launching of a social venture. Nevertheless, the results suggest that these relationships might vary according to the legal structure of the social venture. For example, partnerships might be more important for nonprofit entities than for hybrid social ventures. However, the results suggest that hybrid ventures have a greater competitive advantage than for-profit and nonprofit social ventures. In any case, these findings provide support that the firm creation process of nascent social ventures shares many similarities with traditional commercial ventures.

Finally, this dissertation develops an innovative dataset and measures which can be used to analyze other research questions in the context of social ventures. This study content analyzes 179 social venture business plans and collects follow-up survey data for 72 of these ventures. Thus additional studies can easily analyze other components of these social ventures and even follow them over time. This dissertation also develops an innovative means to measure competitive advantage in the context of nascent social ventures by assessing different components of venture development and value creation, as well as launching.

In summary, this dissertation makes an important contribution to the social venture literature by systematically showing the applicability of the RBV framework to the 
context of nascent social ventures and empirically examining these relationships. The results suggest that partnership diversity, heterogeneous resource conditions, strategies, and competitive advantage are significantly related. These findings have many implications for practitioners and scholarly research and present many additional questions for future research.

\section{Implications}

This study has several implications for both practitioners and scholars. Until recently management social venture research has focused primarily on defining the concept of social entrepreneurship and assessing social ventures through anecdotes and case studies. This dissertation contributes to the growing quantitative empirical research in this field and demonstrates that a large scale study of social ventures can be developed. In addition, the dissertation systematically applies an established theory to the phenomenon and shows the applicability of the RBV to the context of nascent social ventures. This suggests that RBV and other mainstream theories should be used more wholeheartedly in the context of social ventures.

This research also examines the firm creation process in the context of nascent social ventures and shows that it is similar to that of traditional commercial ventures. Better understanding how different factors like partnerships, resources, and strategies contribute to the development of a competitive advantage and the launching of a venture can potentially facilitate the development and success of more social ventures. Other factors 
that contribute to this success should be researched in further detail. In addition, this dissertation examines how a diversity of partnerships with different types of organizations can facilitate venture development and value creation. Most partnership research focuses on analyzing the impact of one type of partnership or a cross-sector partnership between three entities, rather than looking at the multiply embedded network of partnerships in which a social venture actually operates. The findings suggest that the different ramifications of partnership diversity should be analyzed further, just as networks are analyzed extensively in the context of commercial entrepreneurial ventures. Finally, this dissertation develops a database and methodology that can be applied to examine many additional research questions regarding nascent social ventures inputs, processes, and outputs as well as macro elements like educational initiatives and business plan competitions.

This study also suggests some important implications for practitioners. This research suggests that nascent social ventures are more likely to develop and create value if certain conditions are met. For those social ventures emerging as part of a business plan competition, a focus on developing a complete business plan and bringing in founders with previous start-up experience is important to the success of the venture. At the same time, often the most important type of resource to achieving a competitive advantage is social capital. Developing social capital through networking and partnerships is an important means to gain access to new markets, beneficiaries, and resources. Thus nascent social ventures should be sure to focus on developing this social capital. At the same time, developing partnerships with numerous entities from different sectors will 
help social ventures gain different types of resources that will facilitate their development and achievement of their value creation goals. Partnership diversity will also facilitate the launch of nascent social ventures. Partnerships with just corporations, just government entities, or between just two sectors might not be sufficient. Through these findings hopefully social ventures can help improve their effectiveness and facilitate the creation of social value.

At the same time, this dissertation has important implications for sponsors of social venture business plan competitions. If a business plan competition sponsor's primary goal is to develop nascent social ventures, they should focus on helping competition participants gain social capital, establish relationships with other team members who have prior start-up experience, and assist in the development of complete business plans. In addition, facilitating introductions to potential partners with entities from different sectors will facilitate the development of adequate resource conditions and strategic capabilities that are important for nascent social venture success. They will also more likely lead to the launch of the social venture. Finally, some of the results suggest that certain business plan competitions resulted in social ventures that had a greater competitive advantage than other competitions. Perhaps these business plan sponsors can work together to determine which components of their competitions lead to more successful social ventures. 


\section{Future research}

The results from this study suggest many opportunities for research to further increase our understanding of nascent social ventures. This dissertation particularly explores the importance of partnerships and partnership diversity in social venture success, but future research could explore the role of other sources of external resources in this process to attain a competitive advantage. In addition, the importance of particular types of resources could be assessed more thoroughly. How does social capital specifically lead to a competitive advantage? How do social ventures develop social capital? What types of partners are most likely to provide particular types of resources? The relationships in this framework could also be tested on a different sample of social ventures to see if they hold. Does partnership diversity actually lead to heterogeneous resource conditions? How is partnership diversity related to social innovation? Testing these relationships with another sample also might provide the opportunity to develop different measures of partnerships and resources which better assess the degree or level of these variables.

For example a cross-cultural comparative study between social ventures operating in the United States and another country would be interesting to assess if the relationships analyzed in this study hold in other contexts. A qualitative study could provide deeper insight into the importance of specific types of partnerships and the resources they bring for social ventures operating in different international settings. In addition, the competitive advantage of nascent social ventures might vary in different cross-cultural contexts. Business plan data from competitions operating in Brazil and India were 
collected as part of the dissertation and could serve as the basis for a future study of this nature.

Potentially a longitudinal study could be conducted to track social ventures to better assess how the relationship between partnerships, resources, strategies, and a competitive advantage evolves over time. The survey data provides some initial insight into the development of the social ventures analyzed in the business plan by enabling the ability to assess whether these social ventures actually launched. However, perhaps a few of the nascent social ventures from this sample could be analyzed more deeply over time through more extensive interviews. In addition if a larger sample of social ventures participating in business plan competitions could be tracked over time, a greater understanding of the social venture firm creation process could be gained.

The findings also suggest that the importance of partnerships and perhaps even the operational processes of social ventures might vary according to their legal status. How do partnerships differ between nonprofit, for-profit, and hybrid social ventures? How do each of these types of legal entities focus their competitive advantage? Do some of these types of legal structures have better access to resources than others? What types of partnerships are most beneficial for social ventures of particular legal structure? The degree of hybridness could also be further explored as some hybrid social ventures might focus more on reaching their social goals through economic initiatives, while others might be more socially focused. 
The sample also opens up the possibility of better understanding the role of social venture business plan competitions in the university educational system. Is the role of these competitions to actually develop social ventures? How can these competitions better assist with the development of these ventures? What complementary programs or initiatives can be developed to increase the capacity of the social ventures emerging from these competitions? What factors influence success? These are only a few of the areas and potential future research questions that have emerged from this dissertation that could be further developed.

\section{Limitations}

This research has several limitations related to content analysis, the sample, and the use of business plans which might influence the findings. First, human aided content analysis assesses the presence of certain phenomena in the business plans by coding individual binary variables. This does not account for the degree of a certain variable. However, content analysis is a common method used in research, and this dissertation applies the established standards of rigor to attain validity and reliability using this method. In addition, the validity of different variables found using content analysis is sometimes questionable as to whether these variables actually represent the phenomena of interest. Nevertheless, dichotomous variables are often used in the management literature to represent the importance or presence of a particular variable of interest. At the same time, many of the questions coded through the content analysis of the business plans are 
validated through the follow-up survey which asks similar questions of the individuals who participated in the competition (for which plans were content analyzed).

However partnership diversity and resources might be measured in different ways in future research. In the content analysis of the business plans, the measurement of resources represents resources gained through partnerships. This suggests that if partners are coded, then resources will be coded as well. Nevertheless the variable heterogeneous resource conditions is a measure of the different types of resources gained through partnerships. Thus a venture might just gain one type of resource through different partnerships and this measurement concern would not be an issue. In any case, steps are taken to limit this measurement issue. Finally, the reliability of coding different variables based on textual material is questionable as this might represent a perception of reality rather than actual entrepreneurial behavior. However, the development of a robust coding procedure and the use of two coders strengthen reliability and validity.

The analysis of social ventures that participated in business plan competitions also has several limitations. Most individuals who participate in these competitions are students who do not always have the intent to actually start the venture. Rather they may be fulfilling a class requirement or an interest to participate in a competition. In fact, only 55 out of the 72 individuals who took the survey said they actually intended to start the venture. Thus, these findings could represent the beliefs of would-be, but not actual entrepreneurs. Nevertheless, the partnership, resource conditions, strategy, venture development, and value creation survey questions are only asked of social ventures who 
were actually in operation. In any case, the composition of the sample could impact the external validity of the results. The actual competitive advantage variables and resource conditions would not be generalizable to other samples, especially if the operating and start-up conditions are different for social ventures that participate in business plan competitions.

Finally, the use of business plans as a sample has many limitations. Sometimes these plans represent intentions or expectations, but do not tie to real behavior. Although this is partly circumvented by the exploratory survey sample, the size is relatively small which might impact some of the findings as discussed. At the same time, a business plan represents an early stage of a venture. Since ventures that enter business plan competitions are at different stages of early development there could be a greater variation among the sample that is not accounted for merely by participating in the competition.

\section{Concluding words}

This dissertation contributes to the existing literature on social ventures by applying RBV to systematically analyze and empirically test the role partnerships in the attainment of a competitive advantage for nascent social ventures. The findings from two complementary samples suggest a relationship between partnership diversity and a competitive advantage in terms of venture development, value creation, and launching. Founder start-up experience, business plan completeness, client location, and social 
capital are also found to be particularly important to the achievement of a competitive advantage. At the same time, both social innovation and developing various products or services that earn income contribute to the development of a nascent social venture. In addition, partnership diversity is related to the development of heterogeneous resource conditions and strategic capabilities such as social innovation and earned income. Finally, findings suggest that hybrid ventures have a greater competitive advantage than nonprofit and for-profit social ventures. This dissertation provides an exploratory examination into the nature of social ventures that can facilitate their creation of value and benefits to society. Hopefully, this dissertation provides a basis for which future research can be conducted and strategies implemented by social venture practitioners that ultimately result in more social benefits that positively impact and improve society. 


\section{REFERENCES}

Adler, P., \& Kwon, S. 2002. Social capital: Prospects for a new concept. Academy of Management Review, 27: 17-40.

Afuah, A. 2000. How much do your co-opetitors' capabilities matter in the face of technological change?' Strategic Management Journal, 21: 387-404.

Aldrich, H. 1999. Organizations evolving. Thousand Oaks: CA: Sage.

Aldrich, H., \& Auster, E. 1986. Even dwarfs started small: Liabilities of age and size and their strategic implications." In B. Staw, \& L.L. Cummings (Eds.), Research in organizational behavior, Vol. 8: 165-198. Greenwich, CT: JAI Press.

Aldrich, H.E., \& Martinez, M.A. 2001. Many are called, but few are chosen: An evolutionary perspective for the study of entrepreneurship. Entrepreneurship: Theory and Practice, 25: 41-56.

Alvarez, S.A., \& Barney, J.B., 2002. Resource-based theory and the entrepreneurial firm. In M.A. Hitt, R.D. Ireland, S.M. Camp, \& D.L. Sexton, D.L. (Eds.), Strategic entrepreneurship: Creating a new mindset: 89-105. Oxford, UK: Blackwell.

Alvarez, S.A., \& Busenitz, L.W. 2001. The entrepreneurship of resource-based theory. Journal of Management, 27: 755- 776.

Alvord, S. H., Brown, L. D., \& Letts, C.W. 2004. Social entrepreneurship and societal transformation. Journal of Applied Behavioral Science, 40: 260-282.

Anderson, E., \& Jap, S.D. 2005. The dark side of close relationships. MIT Sloan Management Review, 46: 75-82.

Anthony, S.D., Johnson, M. W., Sinfield, J.V., \& Altman, E.J. 2008. The innovator's guide to growth. Boston, MA: Harvard Business Press.

Arsenault, J. 1998. Forging nonprofit alliances. San Francisco: Jossey-Bass.

Austin, J.E. 2000a. Strategic collaboration between nonprofits and businesses. Nonprofit and Voluntary Sector Quarterly, 29: 69-97.

Austin, J.E. 2000b. The collaboration challenge: How nonprofits and business succeed through strategic alliances. San Francisco: Jossey Bass Publishers.

Austin, J.E. 2003. Strategic alliances: Managing the collaboration portfolio. Stanford Social Innovation Review, 1:48-55. 
Austin, J.E., \& Harmeling, S.S. 1999. Women's world banking: Catalytic change through networks. HBS Case No. 9-300-050. Boston: Harvard Business School Publishing.

Austin, J., Gutiérrez, R., Ogliastri, E., \& Reficco, E. 2006. Effective management of social enterprises: Lessons from businesses and civil society organizations in Iberoamerica. Cambridge, MA: Harvard University Press.

Austin, J., Reficco, E., Berger, G., Fischer, R. M., Gutiérrez, R., Koljatic, M., et al. 2004. Social partnering in Latin America: Lessons drawn from collaborations of businesses and civil society organizations. Cambridge, MA: Harvard University Press.

Austin, J.E., Stevenson, H.H., \& Wei-Skillern, J. 2006. Social and commercial entrepreneurship: Same, different, or both? Entrepreneurship Theory and Practice, 30: $1-22$.

Babiak, K., \& Thibault, L. 2009. Challenges in multiple cross-sector partnerships. Nonprofit and Voluntary Sector Quarterly, 38: 117-143.

Barendsen, L., \& Gardner, H. 2004. Is the social entrepreneur a new type of leader? Leader to Leader, 34: 43-50.

Barney, J.B., 1986. Strategic factor markets: Expectations, luck and business strategy. Management Science, 42: 1231-1241.

Barney, J.B. 1991. Firm resources and sustained competitive advantage. Journal of Management, 17: 99-120.

Barringer, B.R., Jones, F.F., \& Neubaum, D.O. 2005. A quantitative content analysis of the characteristics of rapid-growth firms and their founders. Journal of Business Venturing, 20: 663-687.

Baum, J.A.C. 1996. Organizational ecology. In S. Clegg, C. Hardy, \& W. Nord (Eds.), Handbook of organization studies: 77-114. London: Sage.

Baum, J.A.C., \& Oliver, C. 1991. Institutional linkages and organizational mortality. Administrative Science Quarterly, 36: 187-218.

Becker, G.S. 1964. Human capital: A theoretical and empirical analysis, with special reference to education. Chicago: University of Chicago Press.

Berger, I. E., Cunningham, P. H., \& Drumwright, M.E. 2004. Social alliances: Company/ nonprofit collaboration. California Management Review, 47: 58-90. 
Bergmann-Lichtenstein, B.M., \& Brush, C.G. 2001. How do "resource bundles" develop and change in new ventures? A dynamic model and longitudinal exploration. Entrepreneurship, Theory \& Practice, 25: 37-58.

Bhave, M.P., 1994. A process model of entrepreneurial venture creation. Journal of Business Venturing, 9: 223-242.

Bird, B.J., 1989. Entrepreneurial behavior. Glenview, IL: Scott Foresman \& Company.

Bird, B., 1993. Demographic approaches to entrepreneurship: the role of experience and background. Advances in Entrepreneurship, Firm Emergence, and Growth, 1: 1148.

Blodgett, 1991. Partner contributions as predictors of equity share in international joint ventures. Journal of International Business Studies, 22: 63-78.

Bloom, P., \& Smith, B.R. 2009. Identifying the drivers of social entrepreneurial impact: Theoretical development and an exploratory empirical test of SCALERS. Journal of Social Entrepreneurship, 1: 126-145.

Borins, S. 2000. Loose cannons and rule breakers, or enterprising leaders? Some evidence about innovative public managers. Public Administration Review, 60: 498-507.

Boschee, J., \& McClurg, J. 2003. Towards a better understanding of social entrepreneurship: Some important distinctions. From http://www.csen.co/files/Events/TowardsabetterunderstandingofSE.pdf.

Bosma, N., Acs, Z.J., Autio, E., Coduras, A., \& Levie, J. 2008. Global Entrepreneurship Monitor (GEM) $\quad$ Executive $\quad$ Report. http://www.gemconsortium.org/download/1275331725420/GEM Global 08.pdf

Bourdieu, P. 1990. The logic of practice. Cambridge: Polity.

Bozeman, B., \& Bretschneider, S. 1994. The "publicness puzzle" in organization theory: A test of alternative explanations of differences between public and private organizations. Journal of Public Administration Research and Theory, 4: 197-223.

Bozeman, B., \& Corley, E. 2004. Scientists' collaboration strategies: Implications for scientific and technical human capital. Research Policy, 33: 599-616.

Bretherton, P., \& Chaston, I. 2005. Resource dependency and SME strategy: An empirical study. Journal of Small Business and Enterprise Development, 12: 274289.

Brickson, S. 2007. Organizational identity orientation: The genesis of the role of the firm and distinct forms of social value. Academy of Management Review, 32: 864-888. 
Brinkerhoff, P., 2001. Why you need to be more entrepreneurial - and how to get started. Nonprofit World, 19: 12-15.

Brinkerhoff, J. M. 2002. Government-nonprofit partnership: A defining framework. Public Administration and Development, 22: 19-30.

Brock, D., \& Ashoka's Global Academy for Social Entrepreneurship. 2008. Social entrepreneurship teaching resources handbook. Retrieved October 22, 2009. From http://www.universitynetwork.org/sites/universitynetwork.org/files/files/Soc\%20Ent \%20Handbook\%20March\%202008\%20Final.pdf

Brooks, A. 2008. Social entrepreneurship. Upper Saddle River, NJ: Pearson Prentice Hall.

Brown, L.D., \& Ashman, D. 1996. Participation, social capital, and intersectoral problem solving: African and Asian cases. World Development, 24: 1467-1479.

Brown, D.L., \& Kalegaonkar, A. 2002. Support Organizations and the Evolution of the NGO Sector. Nonprofit and Voluntary Sector Quarterly, 31: 231-258.

Brush, C. G., Greene, P. G., \& Hart, M. M. 2001. Creating wealth in organizations: The role of strategic leadership. Academy of Management Executive, 15: 64-78.

Brush, C. G., Manolova, T. S., \& Edelman, L. F. 2008. Properties of emerging organizations: An empirical test. Journal of Business Venturing, 23: 547-566.

Brush, C.G., \& Vanderwerf, P.A. 1992. A comparison of methods and sources for obtaining estimates of new venture performance. Journal of Business Venturing, 7: $157-170$.

Burt, R.S., 1992. Structural holes. Cambridge, MA: Harvard University Press.

Campbell, S. 1997. Social entrepreneurship: How to develop new social-purpose business ventures. Health Care Strategic Management, 16: 17-18.

Carsrud, A.L., \& Brännback, M. 2007. Entrepreneurship. Westport, CT: Greenwood Press.

Carsrud, A. L., Gaglio, C. M., \& Olm, K. 1987. Entrepreneurs - mentors, networks, and successful new venture development: An exploratory study. American Journal of Small Business, 12: 13-18.

Certo, T.S., \& Miller, T.L. 2008. Social entrepreneurship: Key issues and concepts. Business Horizons, 51: 267-271. 
Chapple, W., \& Moon, J. 2005. Corporate social responsibility in Asia: A seven-country study of CSR web site reporting. Business \& Society, 44: 415-441.

Chaudhri, V., \& Wang, J. 2007. Communicating corporate social responsibility on the internet. Management Communication Quarterly, 21: 232-247.

Chell, E. 2007. Social enterprise and entrepreneurship. International Small Business Journal, 25: 5- 26.

Chesbrourgh, H., Ahern, S., Finn, M., \& Guerraz, S. 2006. Business models for technology in the developing world: The role of non-governmental organizations. California Management Review, 48: 48-61.

Child, J., \& Faulkner, D. 1998. Strategies of cooperation: Managing alliances, networks, and joint ventures. London: Oxford University Press.

Choi, D.Y., \& Gray, E.R. 2008. Socially responsible entrepreneurs: What do they do to create and build their companies? Business Horizons, 51: 341-352.

Christensen, C. M., Baumann, H., Ruggles, R., \& Sadtler, T. M. 2006. Disruptive innovation for social change. Harvard Business Review: 94-101.

Christensen, C. M., Grossman, J. H., \& Hwang, J. 2009. The innovator's prescription: A disruptive solution for health care. New York: McGraw Hill.

Cigler, B.A. 1999. Pre-conditions for the emergence of multicommunity collaborative projects. Policy Studies Review, 16: 86-102.

Clark, C., Rosenzweig, W., Long, D., \& Olsen, S. 2004. Double bottom line project report: Assessing social impact in double bottom line ventures methods catalog. New York: Rockefeller Foundation.

Coleman, J.S., 1990. Foundations of social theory. Cambridge, MA: Harvard University Press.

Contractor, F. J., \& Lorange, P. 1988. Why should firms cooperate? The strategy and economics basis for cooperative ventures. In F.J. Contractor, \& P. Lorange (Eds.), Cooperative strategies in international business: 3-30. Lexington, MA: Lexington Books.

Cool, E., \& Vermeulen, S. 2008. What's name in a name? An inquiry on the cognitive and entrepreneurial profile of the social entrepreneur. Retrieved February 15, 2008. From http://www.vlerick.be 
Cooper, A.C., \& Gimeno-Gascon, F.J., 1992. Entrepreneurs, processes of founding and new firm performance. In D.L. Sexton, \& J.D. Kasarda (Eds.), The state of the art of entrepreneurship: 301-340. Boston: PWS-Kent.

Cooper, A. C., Gimeno-Gascon, F. J., \& Woo, C. Y. 1994. Initial human and financial capital as predictors of new venture performance. Journal of Business Venturing, 9: 371-395.

Cummings, T.G. 2007. The quest for an engaged academy. Academy of Management Review, 32: 355-30.

Dacin, M. T., Oliver, C., \& J. Roy, 2007. The legitimacy of strategic alliances: An institutional perspective. Strategic Management Journal, 28:169-187.

Dart, R. 2004. Being "business-like" in a nonprofit organization: A grounded and inductive typology. Nonprofit and Volunteer Sector Quarterly, 33: 290-310.

Das, T.K., \& Teng, B. 2000. A resource-based theory of strategic alliances. Journal of Management, 26: 31-61.

Davidsson, P., \& Honig, B. 2003. The role of human and social capital among nascent entrepreneurs. Journal of Business Venturing, 18: 301-331.

Dees, J.G. 1998. The meaning of social entrepreneurship. Stanford University: Draft Report for the Kauffman Center for Entrepreneurial Leadership. Retrieved March 15, 2009. From: http://www.fuqua.duke.edu/centers/case/documents/dees_SE.pdf

Dees, J.G., \& Anderson, B.B. 2003. For-profit social ventures. International Journal of Entrepreneurship Education, 2: 1-26.

Dees, J.G., \& Anderson, B.B. 2006. Framing a theory of social entrepreneurship: building on two schools of practice and thought. In Mosher-Williams (Ed.), Research on social entrepreneurship: Understanding and contributing to an emerging field, ARNOVA Occasional Paper Series, 1: 39-66.

Delmar, F., \& Shane, S., 2003. Does business planning facilitate the development of new ventures? Strategic Management Journal, 24: 1165-1185.

Desa, G. 2008. Mobilizing resources in constrained environments: A study of technology social ventures. Doctoral dissertation, University of Washington.

Di Domenico, M., \& Haugh, H. 2007. Strategic partnering: Results from a survey of social ventures in the $\boldsymbol{U K}$. Paper presented at the International Social Entrepreneurship Research Conference, Copenhagen, Denmark. 
Di Domenico, M., Tracey, P., \& Haugh, H. 2009. The dialectic of social exchange: Theorizing corporate social enterprise collaboration. Organization Studies, 30: 887-907.

Dierickx, I., \& Cool, K. 1989. Asset stock accumulation and sustainability of competitive advantage. Management Science, 35: 1504- 1511.

DiMaggio, P.J. 1997. Culture and cognition. Annual Review of Sociology, 23: 263-287.

Donckels, R., \& Lambrecht, J., 1995. Networks and small business growth: an explanatory model. Small Business Economics, 7: 273-289.

Donckels, R., \& Lambrecht, J., 1997. The network position of small businesses: an explanatory model. Journal of Small Business Management, 35: 13-25.

Dorado, S., 2006. Social entrepreneurial ventures: Different values so different process of creations, no? Journal of Developmental Entrepreneurship, 11: 319-343.

Doz, Y., \& Hamel, G. 1998. Alliance advantage. Boston: Harvard Business School Press.

Drayton, W. 2002. The citizen sector: becoming as entrepreneurial and competitive as business. California Management Review, 44: 120-132.

Dubini, P., \& Aldrich H., 1991. Personal and extended networks are central to the entrepreneurial process. Journal of Business Venturing, 6: 305-313.

Duriau, V.J., Reger, R.K., \& Pfarrer, M.D. 2007. A content analysis of the content analysis literature in organization studies. Organizational Research Methods, 10: $5-34$.

Dyer, J.H., \& Nobeoka, K. 2000. Creating and managing a high performance knowledgesharing network: The Toyota case. Strategic Management Journal, 21: 345-367.

Dyer, J., \& Singh, H., 1998. The relational view: cooperative strategy and sources of interorganizational competitive advantage. Academy of Management Review, 23: 660-679.

Edelman, L.F., Brush, C.G., \& Manolova, T. 2005. Co-alignment in the resourceperformance relationship: strategy as mediator. Journal of Business Venturing, 20: $359-383$

Eisenhardt, K.M., \& Schoonhoven, C.B. 1996. Resource-based view of strategic alliance formation: Strategic and social effects in entrepreneurial firms. Organization Science, 7: 136-150. 
Elkington, J. 1997. Cannibals with forks: The triple bottom line of $21^{\text {st }}$ century business. London: Capstone.

Elkington, J. 2001. The triple bottom line for 21 st century business. In R. Strakely, \& R. Welford (Eds.), Business and Sustainable Development: 20-43. London: Earthscan.

Emerson, J. 1999. Social return on investment: Exploring aspects of value creation, REDF box set, Vol. 2, Chapter 8. San Francisco: Roberts Enterprise Development Foundation

Emerson, J. 2003. The blending value proposition: Integrating social and financial returns. California Management Review, 45: 35-51.

Emerson, J., \& Bonini, S. 2003. The blended value map: Tracking the intersects and opportunities of economic, social and environmental value creation. From http://www.blendedvalue.org

Emerson, J., Freundlich, T., \& Fruchterman, J. 2007. Nothing ventured, nothing gained. Oxford Working Paper.

Fitzpatrick, J.M., \& Gedaka, K.A. 2003. Success through collaboration. Environmental Science \& Technology, 37: 443A-448A.

Foo, M.D., Wong, P.K., \& Ong, A. 2005. Do others think you have a viable business idea? Team diversity and judges' evaluation of ideas in a business plan competition. Journal of Business Venturing, 20: 385-402.

Foster, M.K., \& Meinhard, A.G. 2002. A regression model explaining predisposition to collaborate. Nonprofit and Voluntary Sector Quarterly, 31: 549-564.

Fox, C., Inter-American Development Bank, Brakarz, J., \& Cruz Fano, A. 2005. Tripartite partnerships: Recognizing the third sector. Washington, D.C.: InterAmerican Development Bank.

Friar, J.H., \& Meyer, M.H. 2003. Entrepreneurship and start-ups in the Boston region: Factors differentiating high-growth ventures from micro-ventures. Small Business Economics, 21: 145-152.

Frisby, W., Thibault, L., \& Kikulis, L. M. 2004. The organizational dynamics of undermanaged partnerships in leisure service departments. Leisure Studies, 23: 109-126.

Froelich, K. A. 1999. Diversification of revenue strategies: Evolving resource dependence in nonprofit organizations." Nonprofit and Voluntary Sector Quarterly, 28: 246-268.

Fukuyama, F. 1995. Trust. New York: Free Press. 
Galaskiewicz, J., Bielefeld, W., \& Dowell, M. 2006. Networks and organizational growth: a study of community based nonprofit. Administrative Science Quarterly, 51: $337-380$

García-Canal, E., Valdéz-Llaneza, A., \& Ariñio, A. 2003. Effectiveness of dyadic and multi-party joint ventures. Organization Studies, 24: 743-770.

Gartner, W. B., Shaver, K. G., Carter, N. M., \& Reynolds, P.D. (Eds.) 2004. Handbook of entrepreneurial dynamics: The process of business creation. Thousand Oaks, CA: Sage.

Gazley, B., \& Brudney, J.L. 2007. The purpose (and perils) of government-nonprofit partnership. Nonprofit and Voluntary Sector Quarterly, 36: 389-415.

Ghemawat, P. 1986. Sustainable advantage. Harvard Business Review, 64:53- 58.

Googins, B. K., \& Rochlin, S. A., 2000. Creating the partnership society: understanding the rhetoric and reality of cross-sectoral partnerships. Business and Society Review, 105: 127-144.

Granovetter, M.S., 1992. Problems of explanation in economic sociology. In N. Nohria, $\&$ R. Eccles (Eds.), Networks and organizations: Structure, form, and action: 2556. Boston: Harvard Business School Press.

Grant, R.M. 1991. The resource-based theory of competitive advantage: Implications for strategy formulation. California Management Review, 33: 114-135.

Grant, R. M., \& Baden-Fuller, C. 1995. A knowledge- based theory of inter-firm collaboration. Best paper proceedings, Academy of Management Conference: 1721.

Gray, B. 1989. Collaborating: Finding common ground for multiparty problems. San Francisco: Jossey-Bass.

Greene, P., \& Brown, T., 1997. Resource needs and the dynamic capitalism typology. Journal of Business Venturing, 12:161-173.

Greene, P. G., Brush, C. G., \& Hart, M. M. 1999. The corporate venture champion: A resource-based approach to role and process. Entrepreneurship Theory and Practice, 23: 103-122.

Gronbjerg, K. A. 1993. Understanding nonprofit funding: Managing revenues in social services and community development organizations. San Francisco: Jossey-Bass.

Gruber, M. 2007. Undercovering the value of planning in new venture creation: A process and contingency perspective. Journal of Business Venturing, 22: 782-807. 
Gulati, R. 1998. Alliances and networks. Strategic Management Journal, 19: 293-317.

Gulati, R., \& Higgins, M.C. 2003. Which ties matter when? The contingent effects of interorganizational partnerships on IPO success. Strategic Management Journal, 24: $127-144$.

Guo, C., \& Acar, M. 2005. Understanding collaboration among nonprofit organizations: Combining resource dependency, institutional and network perspectives. Nonprofit \& Voluntary Sector Quarterly, 34: 340-361.

Haber, S., \& Reichel, A. 2007. The cumulative nature of the entrepreneurial process: The contribution of human capital, planning and environment resources to small venture performance. Journal of Business Venturing, 22: 119-145.

Hamel, G. 1991. Competition for competence and inter-partner learning within international strategic alliances. Strategic Management Journal, 12: 83-103.

Hamel, G., Doz, Y.L., \& Prahalad, C.K. 1989. Collaborate with your competitors and win. Harvard Business Review, 67: 133-139.

Hansen, G.S., \& Wernerfelt, B. 1989. Determinants of firm performance: The relative importance of economic and organizational factors. Strategic Management Journal, 10: 399-411.

Harris, D., \& Helfat, C. 1997. Specificity of CEO human capital and compensation. Strategic Management Journal, 18: 895-920.

Hart, S.L., \& Sharma, S. 2004. Engaging fringe stakeholders for competitive imagination. Academy of Management Executive, 18: 7-18.

Hennart, J. 1988. A transaction cost theory of equity joint ventures. Strategic Management Journal, 9: 36-74.

Hess, D., Rogovsky, N. \& Dunfee, T.W.. 2002. The next wave of corporate community involvement: Corporate social initiatives. California Management Review, 44: 110125.

Hibbert, S. A., Hogg, G., \& Quinn, T. 2001. Consumer response to social entrepreneurship: The case of the Big Issue in Scotland. International Journal of Nonprofit and Voluntary Sector Marketing, 7: 288-301.

Hill, T.L., Kothari, T., \& Shea, M. 2010. Patterns of meaning in the social entrepreneurship literature: A research platform. Journal of Social Entrepreneurship, 1: 5-31. 
Hitt, M.A., Bierman, L., Shimizu, K., \& Kochhar, R. 2001. Direct and moderating effects of human capital on strategy and performance in professional service firms: A resource-based perspective. Academy of Management Journal, 44: 13-28.

Ho Park, S., \& Zhou, D. 2005. Firm heterogeneity and competitive dynamics in alliance formation. Academy of Management Review. 30: 531-554.

Hoang, H., \& Antoncic, B. 2003. Network-based research in entrepreneurship: A critical review. Journal of Business Venturing, 18: 165-187.

Hodge, G., \& Greve, C. (Eds.). 2005. The challenge of public-private partnerships: Learning from international experience. Cheltenham, UK: Edward Elgar.

Hofer, C. W., \& Sandberg, W. R. 1987. Improving new venture performance: Some guidelines for success. American Journal of Small Business, 12: 11-25.

Hofer, C.W., \& Schendel, D. 1978. Strategy formulation: Analytical concepts. St. Paul, MN: West Publishing.

Honig, B. 1998. What determines success? Examining the human, financial, and social capital of Jamaican microentrepreneurs. Journal of Business Venturing, 13: 371394.

Honig, B., \& Karlsson, T. 2004. Institutional forces and the written business plan. Journal of Management, 30: 29-48.

Hoogendoorn, B., Pennings, E., \& Thurik, R. 2009. What do we know about social entrepreneurship: An analysis of empirical research. ERIM Report Series Research in Management. ERS-2009-044-ORG http://hdl.handle.net/1765/16558. 1-23

Huxham, C. (Ed.). 1996. Creating collaborative advantage. Thousand Oaks, CA: Sage.

Jack, S.L. 2010. Approaches to studying networks: Implications and outcomes. Journal of Business Venturing, 25: 120-137.

Kale, P. Dyer, J., \& Singh, H. 2001. Value creation and success in strategic alliances: Alliancing skills and the role of alliance structure and systems. European Management Journal, 19: 463-471.

Kanter, R.M. 1994. Collaborative advantage: The art of alliances. Harvard Business Review, 72: 96-108.

Kanter, R.M. 1999. From spare change to real change: The social sector as beta site for business innovation. Harvard Business Review, 77: 122-132.

Kaplan, R. 2002. The balanced scorecard and nonprofit organizations. Balanced Scorecard Report, 2-6 
Kaplan, R., \& Norton, D. 1996. The balanced scorecard. Boston, MA: Harvard Business School Press.

Kerlin, J. A. 2006. Social enterprise in the United States and abroad: Learning from our differences. Research on Social Entrepreneurship: Understanding and Contributing to an Emerging Field, ARNOVA Occasional Paper Series, 1: 105125.

King, P. J., \& Roberts, N. C. 1987. Policy entrepreneurs: Catalysts for policy innovation. Journal of State Government, 60: 172-178.

Kirsch, D., Goldfarb, B., \& Gera, A. 2009. Form or substance: The role of business plans in venture capital decision making. Strategic Management Journal, 30: 487-515.

Kirzner, I., 1973. Competition and entrepreneurship. Chicago: University of Chicago Press.

Kirzner, I., 1979. Perception, opportunity, and profit. Chicago: University of Chicago Press.

Kistruck, G.M. 2008. Comparative institutional arrangements of social intermediation in developing countries. Doctoral dissertation, University of Western Ontario.

Knight, R.H. 1921. Cost of production and price over long and short periods. Journal of Political Economics, 29: 332.

Kohm, A., La Piana, D., \& Gowdy, H.. 2000. Strategic restructuring: Findings from a study of integrations and alliances among nonprofit social service and cultural organizations in the United States. Chicago: Chapin Hall Center for Children at the University of Chicago.

Kourula, A., \& Halme, M. 2008. Types of corporate responsibility and engagement with NGOs: an exploration of business and societal outcomes. Corporate Governance, 8: 557-570.

Kourula, A., \& Laasonen, S. 2010. Nongovernmental organizations in business and society, management, and international business research: Review and implications from 1998 to 2007. Business \& Society, 49: 35-67.

Krippendorff, K. 2004. Content analysis: An introduction to its methodology. Thousand Oaks, CA: Sage.

Krueger, N., Welsh, D., \& Brock, D.D. 2007. Social entrepreneurship education around the world: What ave we learned so far? Presentation to the Worldwide University Network, Chicago, IL. 
Kuratko, D.F., \& Welsch H.P. 2004. Strategic entrepreneurial growth. Mason, OH: South-Western.

Lange, J.E., Mollov, A., Pearlmutter, M., Singh, S., \& Bygrave, W.D. 2007. Pre-start-up formal business plans and post-start-up performance: A study of 116 new ventures. Venture Capital, 9: 237-256

Lavie, D. 2006. The competitive advantage of interconnected firms: An extension of the resource-based view. Academy of Management Review, 31: 638-658.

Leadbeater, C. 1997. The rise of the social entrepreneur. London: Demos. From http://www.demos.co.uk/files/theriseofthesocialentrepreneur.pdf.

Le Ber, M.L., \& Branzei, O. 2010. (Re)Forming strategic cross-sector partnerships: Relational processes of social innovation. Business Society, 49: 140 - 172.

Lee, C., Kyungmook, L., \& Pennings, J.M., 2001. Internal capabilities, external networks and performance: a study on technology-based ventures. Strategic Management Journal, 22: 615-640.

Liao, J., Welsch, H., \& Moutray, C. 2009. Start-up resources and entrepreneurial discontinuance: The case of nascent entrepreneurs. Journal of Small Business Strategy, 19: 1-15.

Light, P.C. 2006. Searching for social entrepreneurs: Who they might be, where they might be found, what they do. In R. Mosher-Williams (Ed.), Research on social entrepreneurship: Understanding and contributing to an emerging field, ARNOVA Occasional Paper Series 1, no. 3: 13-38.

London, T., \& Hart, S.L. 2004. Reinventing strategies for emerging markets: Beyond the transnational model. Journal of International Business Studies, 35: 350-370.

Lyles, M. A., \& Salk, J. E. 1997. Knowledge acquisition from foreign parents in international joint ventures: An empirical examination in the Hungarian context. In P.W. Beamish, \& J. P. Killing (Eds.), Cooperative strategies, Vol. 2. European Perspectives: $325-355$. San Francisco: New Lexington Press.

Maase, S.J.F.M., \& Bossink, B.A.G. 2010. Factors that inhibit partnering for social startup enterprises Journal of Enterprising Communities, 4: 68-84.

Maase, S.J.F.M., \& Dorst, I.K.H. 2007. Exploring the development process of grassroots social entrepreneurship. Paper presented at the International Social Entrepreneurship Research Conference, Copenhagen, Denmark.

Macdonald, S., \& Chrisp, T. 2005. Acknowledging the purpose of partnership. Journal of Business Ethics, 59: 307-317. 
MacMillan, I.C., Siegel, R., \& Narasimha, S.B. 1985, Criteria used by venture capitalists to evaluate new venture proposals. Journal of Business Venturing, 1: 119- 128.

Mair, J., \& Marti, I. 2006. Social entrepreneurship research: a source of explanation, prediction, and delight. Journal of World Business, 41: 36-44.

Mair, J., \& Marti, I. 2009. Entrepreneurship in and around institutional voids: A case study from Bangladesh. Journal of Business Venturing, 24: 419-435.

Mair, J., \& Noboa, E. 2006. Social entrepreneurship: How intentions to create a social venture are formed. In J. Mair, J. Robinson, \& K.N. Hockerts (Eds.), Handbook of research in social entrepreneurship, 121-135. Palgrave MacMillan.

Makadok, R. 2001. Toward a synthesis of the resource-based and dynamic-capability views of rent creation. Strategic Management Journal, 22: 387-401.

Meyskens, M.A., \& Carsrud, A. 2009. The role of partnerships in early stage social ventures. Paper presented at the CCSBE Conference, Toronto, Canada.

Meyskens, M.A., \& Carsrud, A. 2010. Nascent green-technology ventures: An exploratory study assessing the role of partnership diversity in firm success. Small Business Economics. Under review.

Meyskens, M.A., Carsrud, A. L., \& Cardozo, R. Forthcoming. The impact of resources on the success of social entrepreneurship organizations: The symbiosis of entities in the social engagement network. Entrepreneurship \& Regional Development.

Meyskens, M.A., Robb-Post, C., Stamp, J.A., Carsrud, A.L., \& Reynolds, P.D. 2010. Social venture strategy from a global perspective: An exploratory study assessing Ashoka fellows. Entrepreneurship Theory \& Practice, 34: 661-680.

Miller, T. \& Wesley, C.L. 2010. Assessing mission and resources for social change: An organizational identity perspective on social venture capitalists' decision criteria. Entrepreneurship Theory \& Practice, 34: 705-733.

Mohr, J., \& Spekman, R. 1994. Characteristics of partnership success: Partnership attributes, communication behavior, and conflict resolution techniques. Strategic Management Journal, 15: 135-152.

Morris, M.H., Kuratko, D.F., \& Schindehutte, M. 2001. Towards integration: Understanding entrepreneurship through frameworks. International Journal of Entrepreneurship and Innovation, 2: 35-49.

Morris, M.H., Lewis, P.S., \& Sexton, D.L. 1994. Reconceptualizing entrepreneurship: An input-output perspective. S.A.M. Advanced Management Journal, 59: 21-31. 
Mort, G.S., Weerawardena, J., \& Carnegie, K. 2003. Social entrepreneurship: Towards conceptualization. International Journal of Nonprofit and Voluntary Sector Marketing, 8: 76-88.

Moss, T.W., Short, J.C. Payne, G.T., \& Lumpkin, G.T. 2010. Dual identities in social ventures: An exploratory study. Entrepreneurship Theory \& Practice

Mowery, D.C., Oxley, J.E., \& Silverman, B.S. 1996. Strategic alliances and interfirm knowledge transfer. Strategic Management Journal, 17: 77-91.

Nahapiet, J., \& Ghoshal, S. 1998. Social capital, intellectual capital, and the organizational advantage. Academy of Management Review, 23: 242-266.

Neck, H., Brush, C., \& Allen, E. 2009. The landscape of social entrepreneurship. Business Horizons, 52: 13-19.

Neuendorf, K. A. 2002. The content analysis guidebook. Thousand Oaks, CA: Sage.

Nicholls, A. 2005. Social entrepreneurship. In S. Carter, \& D. Evans-Jones (Eds.), Enterprise and small business: Principles, practice and policy (2nd Ed.). Prentice Hall

Nicholls, A. (Ed.). 2006. Social entrepreneurship: New models of sustainable social change. Oxford: Oxford University Press.

Parise, S., \& Casher, A. 2003. Alliance portfolios: Designing and managing your network of business partner relationships. Academy of Management Executive, 17: 25-39.

Pearce, J., \& Doh, J.P. 2005. The high impact of collaborative social initiatives. Sloan Management Review, 46: 329-339.

Penrose, E.T. 1959. The theory of the growth of the firm. Oxford: Blackwell.

Peredo, A.M., \& Chrisman, J.J. 2006. Toward a theory of community-based enterprise. Academy of Management Review, 31: 309-328.

Peredo, A.M., \& McLean, M. 2006. Social entrepreneurship: A critical review of the concept. Journal of World Business, 41: 56-65.

Perrini, F., \& Vurro, C. 2006. Social entrepreneurship: Innovation and social change across theory and practice. In J. Mair, J. Robinson, \& K.N. Hockerts (Eds.) Handbook of research in social entrepreneurship: 57-85. Palgrave MacMillan.

Peteraf, M.A. 1993. The cornerstones of a competitive advantage: A resource-based view. Strategic Management Journal, 14: 179-191. 
Pfeffer, J., \& Salancik, G.R. 1978. The external control of organizations: A resource dependence perspective. New York: Harper and Row.

Pharr, S.J. 2003. Preface. In F.J. Schwartz, \& S.J. Pharr (Eds.). The state of civil society in Japan: xiii-xviii. Cambridge, UK: Cambridge University Press.

Phills, J. A., Deiglmeier, K., \& Miller, D. T. 2008. Rediscovering social innovation. Stanford Social Innovation Review, 6: 34-43.

Porter, M.E. 1985. Competitive advantage. New York: Free Press.

Porter, M.E., \& Kramer, M. R. 2002. The competitive advantage of corporate philanthropy. Harvard Business Review, 80: 57-68.

Powell, W.W., \& Clemens, E. S. 1998. Private action and public good. New Haven, CT: Yale University Press.

Prahalad, C.K. 2005. The fortune at the bottom of the pyramid: Eradicating poverty through profits. Upper Saddle River, NJ: Wharton School Publishing.

Prahalad, C.K., \& Hamel, G. 1990. The core competence of the organization. Harvard Business Review, 68: 79-91.

Prahalad, C.K., \& Hammond, A. 2002. Serving the world's poor, profitably. Harvard Business Review, 80: 48-57.

Premaratne, S.P., 2001. Networks, resources and small business growth: the experience in Sri Lanka. Journal of Small Business Management, 39: 363-371.

Preston, L.E., \& Donaldson, T. 1999. Stakeholder management and organizational wealth. Academy of Management Review, 24: 619-620.

Provan, K. G., Isett, K. R., \& Milward, H. B. 2004. Cooperation and compromise: A network response to conflicting institutional pressures in community mental health. Nonprofit and Voluntary Sector Quarterly, 33: 489-514.

Provan, K.G., \& Milward, H.B. 1995. Do networks really work? A framework for evaluating public-sector organizational networks. Public Administration Review, 61: 414-423.

Rangan, V. K., Quelch, J. A., Herrero, G., \& Barton, B. 2007. Business solutions for the global poor: Creating social and economic value. San Francisco: Jossey-Bass.

Reynolds, P.D., \& Curtin, R. 2008. Business creation in the United States: Panel study of entrepreneurial dynamics II initial assessment. Foundations and Trends in Entrepreneurship, 4: 155. 
Ring, P., \& Van de Ven, A. 1992. Structuring cooperative relationships between organizations. Strategic Management Journal, 13: 483-498.

Robinson, J. 2006. Navigating social and institutional barriers to markets: How social entrepreneurs identify and evaluate opportunities. In J. Mair, J. Robinson, \& K.N. Hockerts (Eds.), Handbook of research in social entrepreneurship: 95-120. Palgrave MacMillan.

Robinson, P., \& Sexton, E., 1994. The effect of education and experience on selfemployment success. Journal of Business Venturing, 9: 141-156.

Rodan, S., \& Galunich, C. 2004. More than network structure: How knowledge heterogeneity influences managerial performance and innovativeness. Strategic Management Journal, 25: 541-562.

Rondinelli, D.A., \& London, T. 2003. How corporations and environmental groups cooperate: Assessing cross-sector alliances and collaborations. Academy of Management Executive, 17: 61-76.

Ronstadt, R. 1984. Entrepreneurship. Dover, MA: Lord.

Ruef, M. 2005. Origins of organizations: The entrepreneurial process. In L. Keister (Ed.), Research in the sociology of work: 14

Saidel, J.R. 1994. The dynamics of interdependence between public agencies and nonprofit organizations. Research in Public Administration, 3: 210-229.

Salamon, L.M. 2002 The resilient sector: The state of nonprofit America. In L.M. Salamon (Ed.), The state of nonprofit America: 3-61. Washington, DC: Brookings Institution.

Schaeffer, P. V., \& S. Loveridge. 2002. Toward an understanding of types of publicprivate cooperation. Public Performance and Management Review, 26: 169-189.

Schlee, R.P., Curren, M.T., \& Harich, K.R. 2009. Building a marketing curriculum to support courses in social entrepreneurship and social venture competitions. Journal of Marketing Education, 31: 5-15.

Schumpeter, J. 1934. Capitalism, socialism, and democracy. New York: Harper \& Row.

Scott, R. 1987. Organizations: Rational, natural and open systems. Englewood Cliffs, NJ: Prentice Hall.

Seelos, C., \& Mair, J. 2005. Sustainable development, sustainable profit. European Business Forum, 20: 49-53. 
Seelos, C., \& Mair, J., 2007. Profitable business models and market creation in the context of deep poverty: A strategic view. Academy of Management Perspectives, 21: 49-63.

Seitanidi, M.M. 2008. Adaptive responsibilities: Nonlinear interactions in cross sector social partnerships. Emergence: Complexity \& Organization, 10: 51-64.

Shane, S., \& Venkataraman, S. 2000. The promise of entrepreneurship as a field of research. Academy of Management Review, 25: 217-226.

Sharfman, M.P., Gray, B., \& Yan, A. 1991. The context of interorganizational collaboration in the garment industry: An institutional perspective. Journal of Applied Behavioral Science, 27:181.208.

Sharir, M., \& Lerner, M., 2006. Gauging the success of social ventures initiated by individual social entrepreneurs. Journal of World Business, 41: 6-20.

Shaw, E., 2004. Marketing in the social enterprise context: Is it entrepreneurial? Qualitative Marketing Research: an International Journal, 7: 194-205.

Shaw, E., Shaw, J., \& Wilson, M. 2002. Unsung entrepreneurs: Entrepreneurship for social gain. Durham, UK: University of Durham Business School - The Barclays Centre for Entrepreneurship.

Shaw, E., \& Carter, S. 2007. Social entrepreneurship: Theoretical antecedents and empirical analysis of entrepreneurial processes and outcomes. Journal of Small Business and Enterprise Development, 14: 418-434.

Short, J. Moss, T.W., \& Lumpkin, G.T. 2009. Research in social entrepreneurship: Past contributions and future opportunities. Strategic Entrepreneurship Journal, 3: 161194.

Singh, K., \& Mitchell, W. 1996. Precarious collaboration: Business survival after partners shut down or form new partnerships. Strategic Management Journal, 17: 99-115.

Southern, A. 2001. What matters is what works? The management of regeneration. Local Economy, 16: 264-271.

Stevenson, H.H. 2008. How to change the world. Harvard Business Review, 86: 29-33.

Stinchcombe, A. L. 1965. Social structure and organizations. In J.G. March (Ed.), Handbook of organizations. Chicago: Rand McNally.

Stone, M.M., Bigelow, B., \& Crittenden, W. 1999. Research on strategic management in nonprofit organizations: Synthesis, analysis, and future directions Administration \& Society, 31: 378-423. 
Stopford, J.M., \& Baden-Fuller, C.W.F. 1994. Creating corporate entrepreneurship. Strategic Management Journal, 15: 521-536.

Su, Y., Tsang, E.W.K., \& Peng, M.W. 2009. How do internal capabilities and external partnerships affect innovativeness? Asian Pacific Journal of Management. 26: 309331.

Tan, W.L., Williams, J., \& Tan, T.-M., 2005. Defining the 'social' in 'social entrepreneurship': altruism and entrepreneurship. International Entrepreneurship and Management Journal, 1: 353-365.

Tapsell, C., \& Woods, C. 2008. A spiral of innovation framework for social entrepreneurship: Social innovation at the generational divide in an indigenous context. Emergence: Complexity and Organization, 10: 25-34.

Teece, D. J. 1986. Profiting from technological innovation: Implications for integration, collaboration, licensing and public policy. Research Policy, 15: 285-305.

Teece, D.J., Pisano, G., \& Shuen, A., 1997. Dynamic capabilities and strategic management. Strategic Management Journal, 18: 509-533.

Teegan, H., Doh, J.P., \& Vachani, S. 2004. The importance of nongovernmental organizations in global governance and value creation: An international business research agenda. Journal of International Business Studies, 35: 463-483.

Teng, B.S. 2007. Corporate entrepreneurship activities through strategic alliances: A resource-based approach toward competitive advantage. Journal of Management Studies, 44: 119-142.

Townsend, D.A., \& Hart, T. 2008. Perceived institutional ambiguity and the choice of organizational form in social entrepreneurial ventures. Entrepreneurship Theory \& Practice, 32: 685-700.

Turpin, T., Garrett-Jones, S., \& Diment, K. 2005. Scientists, career choices and organizational change: Managing human resources in cross-sector R\&D organizations. Journal of the Australian and New Zealand Academy of Management, 11: 13-26.

Van de Ven, A.H., Sapienza, H.J., \& Villanueva, J. 2007. Entrepreneurial pursuits of selfand collective interests. Strategic Entrepreneurship Journal, 1: 353-370.

Van Slyke, D.M., \& Newman, H.K. 2006. Venture philanthropy and social entrepreneurship in community redevelopment. Nonprofit Management and Leadership, 16: 345-368. 
Venkataraman, S. 1997. The distinctive domain of entrepreneurship research, Advances in entrepreneurship, firm emergence and growth. Greenwich, CT: JAI Press, Inc.

Waddell, S. 2005. Societal learning and change. Sheffield, United Kingdom: Greenleaf Publications.

Waddock, S. 1988. Building successful social partnerships. Sloan Management Review, 29: 17-23.

Waddock, S.A., \& Post, J.E. 1991. Social entrepreneurs and catalytic change. Public Administration Review, 51: 393-401.

Waddock, S.A., \& Post, J.E., 1995. Catalytic alliances for social problem solving. Human Relations, 48: 951-973.

Webb, J.W., Kistruck, G.M., Ireland, R.D., \& Ketchen, D.J. 2009. The entrepreneurship process in base of the pyramid markets: The case of multinational enterprise/nongovernment organization alliances. Entrepreneurship Theory \& Practice, 34: 555-581.

Weerawardena, J., \& Mort, G.S. 2001. Learning, innovation and competitive advantage in not-for-profit aged care marketing: A conceptual model and research propositions. Journal of Nonprofit \& Public Sector Marketing, 9: 53-73.

Weerawardena, J., \& Mort, G.S. 2006. Investigating social entrepreneurship: A multidimensional model. Journal of World Business, 41: 21-35.

Wen, C.T., \& Chen, Y.W. 2007. The innovation process of entrepreneurial teams in dynamic business plan competition: from sense-making perspective. International Journal of Technology Management, 39: 346-363.

Wernerfelt, B. 1984. A resource-based view of the firm. Strategic Management Journal, 5: $171-180$.

Whitman, 2009. Measuring social values in philanthropic foundations. Nonprofit Management and Leadership, 19: 305-325.

Williamson, O.E.1985. The economic institutions of capitalism. New York: Free Press.

Williamson, O.E. 1991. Comparative economic organization: The analysis of discrete structural alternatives. Administrative Science Quarterly, 36: 269- 296.

Wilson, F. 2009. Socially conscious capitalism: A study of hybrid enterprises. Doctoral dissertation, Boston University.

Wondolleck, J.M., \& Yaffee, S.L. 2000. Making collaboration work. Lessons from natural resource management. Washington, DC: Island. 
Zadek, S. 1998. Balancing performance, ethics, and accountability. Journal of Business Ethics, 17: 1421-1441.

Zahra, S., Gedajlovic, E., Neubaum, D., \& Shulman, J. 2009. A typology of social entrepreneurs: Motives, search processes and ethical challenges. Journal of Business Venturing, 24: 519-532.

Zhao, L., \& Aram, J.D. 1995. Networking and growth of young technology-intensive ventures in China. Journal of Business Venturing, 10: 349-370. 


\section{Appendix 1: Institutional Review Board Approval}

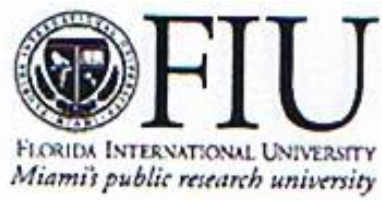

Office of Research Integrity

Research Compliance, MARC 430

\section{MEMORANDUM}

To:

CC:

From:

Date:

Proposal Title:
Moriah Meyskens

Dr. Alan Carsrud

File

Chris Grayson, CIM, Asst. Director of Research Compliance October 22, 2008

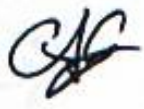

Social Venture Business Plan Competition Research.

Approval \# 101708-00

Your study was deemed Exempt by the Institutional Review Board at Florida International University on October 17, 2008.

As a requirement of IRB approval you are required to:

1) Submit a completion report (Form B-2) upon completion of your project in order for the file to be closed.

2) Submit a proposal and receive approval for any additions or changes in the procedures involving human subjects.

3) Provide immediate written notification to the IRB of every serious or unusual or unanticipated adverse event as well as problems with the rights or welfare of the human subjects. You must confirm the receipt of serious AE reports with the IRB office.

Special Conditions: The final version of the interview questions must be submitted to an IRB Representative via Form B-1 amendment prior to implementation.

Please note your approval number is indicated above. For further information, you may contact the IRB Coordinator by email at irbiacuc@fiu.edu or visit the ORI - Human Subjects website at
http://ori.fiu.edu/IRB.html. 


\section{MEMORANDUM}

$\begin{array}{ll}\text { To: } & \text { Moriah Meyskens } \\ \text { CC: } & \text { Dr. Karen Paul }\end{array}$

File

From: $\quad$ Chris Grayson, CIM, Asst. Director of Research Compliance O\&

Date: $\quad 10 / 01 / 09$

Proposal Title: "Social Venture Business Plan Competition Research"

Approval \# 101708-00

The Institutional Review Board has approved the following modification(s):

$>$ Removal of Dr. Alan Carsrud as the Faculty Supervisior and Investigator

$>$ Addition of Dr. Karen Paul as the Faculty Supervisior and Investigator

$>$ Addition of the Pilot Study Survey Instrument to the study

$>$ Revisions to the Verbal Informed Consent Script to reflect the change in contact information

$>$ Revisions to the IRB proposal to reflect the new school year

There are no additional requirements in regards to your study. However, if there are changes in the protocol after you commence your study that may increase the risks that the human subjects are exposed to, then you are required to resubmit your proposal to a Representative of the IRB for review. For further information, you may visit the ORI - Human Subjects website at http://ori.fiu.edu/IRB.html. 


\section{MEMORANDUM}

To: $\quad$ Moriah Meyskens

CC: Dr. Karen Paul

From: $\quad$ File $\quad$ Chris Grayson, CIM, Associate Director of Research Compliance 48

Date: $\quad 03 / 29 / 10$

Proposal Title: "Social Venture Business Plan Competition Research"

Approval \# 101708-00

The Institutional Review Board has approved the following modification(s):

$>$ Revisions to the Social Venture Survey to gather additional variables needed for analysis of data

$>$ Addition of FIU Dissertation Fellowship and FIU Kauffman Doctoral Student Assistantship as funding sources for this study

There are no additional requirements in regards to your study. However, if there are changes in the protocol after you commence your study that may increase the risks that the human subjects are exposed to, then you are required to resubmit your proposal to a Representative of the IRB for review. For further information, you may visit the ORI - Human Subjects website at http://ori.fiu.edu/IRB.html. 


\section{Appendix 4: Initial Sponsor Contact Email}

\section{Dear Sponsor,}

I am a PhD student in Management \& International Business at Florida International University and am at the beginning stages of my dissertation.

I plan to analyze social venture business plans to assess partnership trends and follow-up with interviews and a survey. I am interested in looking at social venture business plans that participated in business plan competitions and how they fared over time. Ideally I will develop a database that can be used to assess multiple research questions regarding social venture formation and survival as Ill as the impact of social venture business plan competitions. I would like to assess business plans from multiple business schools, foundations and corporations.

Since your organization has a business plan competition, I would be very interested in conducting a content analysis of existing plans since inception.

I would welcome the opportunity to speak with you about the possibility of accessing these plans and/or sending an email on my behalf to past participants to see if they are interested.

I look forward to hearing from you.

Kind regards,

Moriah Meyskens

PhD Student \& Instructor

Florida International University

International Business \& Management

mmeyskens@gmail.com

mmeys001@,fiu.edu

(305) 302-4201 


\section{Appendix 5: Email to Past Participants Sent through Sponsoring Institutions}

Dear Past Social Venture Business Plan Participant,

Do you want to further strengthen the social entrepreneurship field and make an even greater difference than you already are? Do you want to assist in better understanding social venture best practices and the role of partnerships in social ventures? Now you have the opportunity!!

I am a $\mathrm{PhD}$ student in Management \& International Business at Florida International University and am at the beginning stages of my dissertation. I would like to work with you to gain greater insight into these questions by analyzing the business plan you submitted to the $\mathbf{x x}$ social venture business plan competition. I will not share the individual components of your business plan with others, but will analyze general trends across numerous plans submitted to different competitions.

Through my research I am interested in better understanding social venture formation, success, and the impact of business plan competitions. In my dissertation I plan to focus on analyzing social venture business plans to assess partnership trends and follow-up with interviews and a survey. My hope is that through my research we can gain greater insight into social venture best practices and one form of financial and development support (business plan competitions) to provide insights to social venture management to make a greater difference in the world.

I plan to start this dissertation work by assessing business plans from multiple business schools, foundations and corporations. Please contact me at moriah.meyskens@, fiu.edu if you are willing to participate in this exciting study and let me read your business plan. I also have a confidentiality agreement that we can both sign to ensure confidentiality. Participation is completely voluntary and private. Your individual information, business plan, and strategies will not be exposed to other parties.

I would welcome the opportunity to speak with you about the possibility of accessing your plan if you have any additional question. You can also find out more information about me and my work at http://ib.fiu.edu/phd/phd_profile.cfm?PantherID=2282145. .

I look forward to hearing from you.

Kind regards,

Moriah Meyskens

$\mathrm{PhD}$ Student \& Instructor

Florida International University, International Business \& Management

mmeyskens@gmail.com

mmeys001@fiu.edu

(305) 302-4201 


\section{Appendix 6: Direct Email to Past Participants}

\section{Dear xxx,}

xxx from the $\mathrm{xx}$ Business Plan Competition recommended that I contact you. I am a PhD student conducting dissertation research on social ventures and wanted to see if it was possible for you to email the business plan you submitted to the xxx competition.

I will not share the individual components of your business plan with others, but will analyze general trends across numerous plans submitted to different competitions. I also have a confidentiality agreement that we can both sign to ensure confidentiality. Your individual information, business plan, and strategies will not be exposed to other parties.

Through my research I am interested in better understanding social venture formation, success, and the role of partnerships in social ventures. In my dissertation I plan to focus on analyzing social venture business plans to assess partnership trends and follow-up with interviews and a survey. My hope is that through my research we can gain greater insight into social venture best practices and one form of financial and development support (business plan competitions) to provide insights to social venture management to make a greater difference in the world.

I would welcome the opportunity to speak with you about the possibility of accessing your plan if you have any additional question. You can also find out more information about me and my work at http://ib.fiu.edu/phd/phd profile.cfm?PantherID=2282145. .

I look forward to hearing from you.

\section{Moriah Meyskens}

$\mathrm{PhD}$ Student \& Instructor

Florida International University

Department of Management \& International Business

mmeyskens@gmail.com

(305) 302-4201 


\section{Appendix 7: Confidentiality Agreement}

It is understood and agreed to that the below identified discloser of confidential information may provide certain information that is and must be kept confidential. To ensure the protection of such information, and to preserve any confidentiality necessary under patent and/or trade secret laws, it is agreed that

1. The Confidential Information to be disclosed can be described as and includes:

Invention description(s), technical and business information relating to proprietary ideas and inventions, ideas, patentable ideas, trade secrets, drawings and/or illustrations, patent searches, existing and/or contemplated products and services, research and development, production, costs, profit and margin information, finances and financial projections, customers, clients, marketing, and current or future business plans and models, regardless of whether such information is designated as "Confidential Information" at the time of its disclosure.

2. The Recipient agrees not to disclose the confidential information obtained from the discloser to anyone unless required to do so by law.

3. This Agreement states the entire agreement between the parties concerning the disclosure of Confidential Information. Any addition or modification to this Agreement must be made in writing and signed by the parties.

4. If any of the provisions of this Agreement are found to be unenforceable, the remainder shall be enforced as fully as possible and the unenforceable provision(s) shall be deemed modified to the limited extent required to permit enforcement of the Agreement as a whole.

WHEREFORE, the parties acknowledge that they have read and understand this Agreement and voluntarily accept the duties and obligations set forth herein.

\section{Recipient of Confidential Information:}

Name: $\underline{\text { Moriah Meyskens }}$

Signature:

Date:

\section{Discloser of Confidential Information:}

Name:

Signature:
Venture:

Date: 


\section{Appendix 8: Sponsoring Institution Phone Meeting - Questions Asked}

1. Who participates in the competition?

2. Who participated in the 2009 competition?

3. How many people have participated in the plans?

4. What is the business plan competition process?

5. Do you provide training for business plan competition participants?

6. How long have you had the competition?

7. What kind of follow-up do you do with participants?

8. Do you measure the impact of the business plan competition on participants? How?

9. Do you offer follow-up funding?

10 . Who does the prize money go to?

11. How many businesses actually proceeded with the idea?

12. What are some possible next steps to work together? 


\section{Appendix 9: Codebook}

\section{CODING PROCEDURE}

\section{Project Description}

The goal of this project is to code business plans according to certain categories. Each business plan is read and the text representing different categories are coded (highlighted) as nodes in NVivo if they are represented in the plan. If a variable is not represented in the business plan then it is left blank. When a node is coded (or highlighted) with NVivo this represents a binary ( 1 or 0$)$ variable that can be later analyzed to represent the presence of different characteristics in a social venture.

\section{Instructions}

NVivo. Code the following categories in NVivo while reading the business plan: Demographic, Partnerships, and Value. Within each of these categories individual variables are coded. An area of the business plan is coded by highlighting it with the mouse, right clicking and coding to an existing tree node as indicated below. A highlighted area should be coded under multiple nodes or categories as appropriate. However, once the first instance of a variable is coded as being present, it is not necessary to code additional instances of that variable.]

Excel. An "X" should be placed in the box of the excel spreadsheet if a tree node has been coded (highlighted). Otherwise leave the box blank. This is important to ensure all categories are assessed and to later evaluate inter-rater reliability. Inter-rater reliability assesses the percentage agreement between coders. A few items should be coded manually into Excel and in the NVivo casebook. These include (but are not limited to) the amount of financing received, financing from the team, financing sought, employees, and revenue for first four years of operations. The NVivo casebook can be accessed by going to Tools/Casebook/Open Casebook.

\section{Exploratory Analysis}

In order to fine tune the coding procedure and ensure its reliability, an exploratory analysis is conducted. Different types of social ventures are coded to develop and refine these categories. Each week the results between the two coders will be compared and discussed to ensure the coders are strictly following the codebook.

Only text that represents actual variables should be coded. If a variable is not mentioned in the business plan then do not code it and leave the corresponding excel spreadsheet cells blank. Only code with NVivo those variables that are discussed in the business plan as follows:

\section{I. [DEMOGRAPHIC]}

\section{A. General}

1. [IMPACT] In what area does the venture have the most impact? How is the venture helping society? If it is not clear which area the venture is most impacting, then focus on 
the impact talked most about in the social impact or SROI section. If there is no social impact or SROI sections, then use the executive summary to determine the primary area of impact. Only include one area of impact that is the most prominent.

- [Impact_Dvpt] - In urban and economic development. Helping development in construction or helping to improve the economic development of a region.

- [Impact_Educ] - In education

- [Impact_Envt] - In the environment or energy

- [Impact_Health] - In health. This can include mental health.

- [Impact_Nonprofit] - Assist in growth of nonprofit sector through support of sector as a whole.

- [Impact_Poverty] - In poverty alleviation

\section{2. [LOCATION]}

- [CIntLoc]. In what continent does the venture have the most impact on its clients or beneficiaries? This is where the clients or beneficiary will be located (proposed location) even if the venture has not started. If have different clients and beneficiary locations, then focus on the beneficiary location. A social venture might sell a product to a client and the beneficiary might be the individual or group that benefits from the social ventures mission. Sometimes the client and beneficiary are the same, but sometimes they are different.

$\circ$ [ClntLoc_Africa] Primary client location is in Africa.

- [ClntLoc_Asia] Primary client location is in Asia.

$\circ$ [ClntLoc_Glob] Primary client location is global in nature (no specific countries).

- [ClntLoc_India] Primary client location is in India. If client location is India also mark Asia as the client location.

○ [ClntLoc_Latam] Primary client location is in Latin America.

$\circ$ [ClntLoc_US] Primary client location is in the United States. If the client location is not listed, then assume it is the United States since the business plan competition took place in the United States.

- $\quad$ [HQLoc] In what continent are the headquarters or primary offices of the venture located? If the venture has not started yet, enter the proposed location. This is where the headquarters will be located (proposed location) even if the venture has not started.

○ [HQLoc_Africa] The headquarters are located in Africa.

- [HQLoc_Asia] The headquarters are located in Asia.

- [HQLoc_Glob] The headquarters are in many countries.

O [HQLoc_India] The headquarters are located in India. If the headquarters are in India also mark Asia as the headquarters.

- [HQLoc_Latam] The headquarters are located in Latin America.

- [HQLoc_US] The headquarters are located in the United States. If the headquarter location is not listed, then assume it is the United States since the business plan competition took place in the United States. 
3. [Mgmt]. The management is discussed in detail generally in a section in the business plan. Each of the following areas should be highlighted where they are discussed in the business plan and coded accordingly. In addition, the corresponding numbers should be indicated in excel and the casebook if they are available in the business plan.

- [Mgmt_Profexp]-This section refers to the management team members that will directly be involved with the business. Review the resumes for the total number of years worked, but if not available look at the management bio. Input into EXCEL and casebook your choice on the scale below.

○ $\quad \mathbf{0}$ - No professional experience at all, only part time jobs, been a student

- 1 - Volunteered or worked part time or for a summer or for less than a year or has some experience (length can't be determined) in the area of the social venture or business experience

○ 2 - Management team combined has worked 1-4 years full time in area relevant to the social venture or business experience (Peace Corp volunteer is a full time occupation)

○ 3-Management team combined has worked 5-9 years full time in area relevant to social venture or business experience (Peace Corp volunteer is a full time occupation)

○ 4 -Management team combined has worked 10 years or more full time in area relevant to social venture or business experience (Peace Corp volunteer is a full time occupation)

○ 5 -Management has already had a successful venture in the area of the social venture

- [Mgmt_Startup] - Someone on the team has previously started a venture, or been closely involved (like the first employee) with the startup of the venture or developed their own private practice. This does not include just owning a business!! The management has to have been involved with the actual start up of a venture.

- [Mgmt_Startuptot] - Number of ventures started total by management. Input into EXCEL and casebook. If no one of the management began a start up then code it as ' 0 '.

- [Mgmt_FT] - Number of management team members dedicated full-time to the proposed venture (part time is equal to one-half) at the time the business plan was written. If the team members are in school full time then do not include them. Only include students as working full time for the venture, if the business plan explicitly says so. In EXCEL and casebook. If there is no management that works full time for the venture, then code it as " 0 ".

4. [PLAN_Compl]. In order to assess the completeness of the plan each of these areas should be coded in the plan.

- [PlanCompl_Balance Sheet]. The business plan includes a table of the balance sheet or statement of financial position that includes the assets and liabilities.

- [PlanCompl_Income] The business plan includes the income statement or 
profit/loss statement or Statement of Activities (table).

- [PlanCompl_CashFlow]. The business plan includes a cash flow statement.

- [PlanCompl_Finwritten]. The business plan includes a written section which explains the financials.

- [PlanCompl_MktStrat] - Does the business plan have a section that identifies the target market, marketing plan, strategy, or operations section? Has the venture identified or gathered information about the market opportunity (problem or need and its size? Market analysis?) Has the plan described the target market or how it will be reached? Has the plan described why or how the product or service is a solution to a problem in the target market? Who are the competitors (not mandatory)? The initial part of the section that discusses the market opportunity should be highlighted in the business plan. If the plan does not include this section, then it should not be coded. One section can detail both market and strategy components. Has the venture detailed a compelling market strategy? Does the plan illustrate how it will target this market? How will they implement their operations? The initial part of the section that discusses the strategy should be highlighted in the business plan. How exactly are they going to reach plan? If the plan does not include this section, then it should not be coded. One section can detail both market and strategy components.

- [PlanCompl_Socimp]- Does the business plan have a social impact or SROI section or section focused exclusively on social impact or benefits? This section should describe quantitatively or qualitatively who it will help and how? If the plan does not include this section, then it should not be coded.

- [PlanCompl_Mgmt]- Does the plan have a management section which details the bios of team members or founders of the venture? This should be more then just the resume. The management section must detail the bios of team members or founders to be coded. If the plan does not include this section or does not include the bios of management, then it should not be coded.

B. [ORG STRUCTURE]. What is the status and activities of the social venture?

1. [ACTIVITIES]. Does the business plan mention that any of these activities have been completed? If an activity has been completed then the area in the business plan where it is discussed should be highlighted and coded accordingly as indicated below. Be sure to pay attention to these activities!

- [Act_Acctg] - The venture has hired an accountant.

- [Act_BankAcct] - The venture has opened a bank account

- [Act_BusReg] - The venture has filed state unemployment insurance, federal FICA payment, or income tax. 
- [Act_CashFlow] - The venture already has had at least a month of positive cash flow.

- [Act_ClientPay] - The venture already has a paying client or a letter of intent for a service or product from a client.

- [Act_ClientPot] - The venture has identified a client or end consumer and actually spoken to them about the product or conducted a survey of potential clients or previous clients. Ideally in a market or potential revenue section and refers to their interest in buying the product.

- [Act_Employ] - The proposed venture has pinpointed and actually hired first volunteer or staff person (besides management). These are current or present employees not expected future employees. In EXCEL and the casebook, the number of volunteers or staff should be detailed. Full time employees should be counted as ' 1 ' and part-time employees as ' $1 / 2$ '.

- [Act_FileEIN] - The venture has filed for an employee identification number (EIN).

- [Act_FTDevote] - At least one team member - management or staff is devoted full time to the venture

- [Act_Incorp] - The venture has legally incorporated or formed a legal entity or submitted paperwork to be incorporated.

- [Act_IncorpYr] - The year the venture was incorporated or submitted it's paperwork to be incorporated. Year incorporated should be included in Excel and the Casebook.

- [Act_Law] - The venture has hired a lawyer.

- [Act_Mat] - The venture has purchased materials, office equipment, supply or inventory

- [Act_PatentFile] - A patent has been filed.

- [Act_PatentGrant] - A patent for the venture has been granted.

- [Act_Pilot] - A pilot project has been implemented or is in progress.

- [Act_Proto] - A prototype or model initiated or has already been developed.

- [Act_Rep]- A system or manual or process in place to replicate programs in multiple locations.

- [Act_Rev] - The plan details expected revenue or income for the next four years. This is the total number for the year - you shouldn't have to calculate it. If you have to calculate it, then do not include it. The amount of revenue for year 0 , year 1 , year 2, and year 3 should be indicated in EXCEL and the casebook. If various revenue streams in the financials or venture, then add them together. Base year off of what is in the business plan. Use the same year that is indicated in the business plan. If inconsistencies in the business plan, go with the amount that is in the table or that is most often quoted. This is in thousands to the one decimal place. Always use gross revenue.

- [Act_ScaleAch] - Actually implemented business and already operating in more then one geographic areas or serving multiple populations.

- [Act_Space] - The venture has rented or secured physical space. This does not include a home office.

- [Act_StartOps] - The venture is already providing services 
- [Act_Web] - The venture has an internet website since the website is listed in the plan.

2. [CompAdv] - This section should be coded only if the business plan includes a competitive advantage or competitive analysis section or if the executive summary talks about the competitive advantage. The corresponding section must say something like the "competitive advantage is..." or "the strength that is different from competitors is..." in the sentence where the competitive advantage is identified. If there is no competitive advantage or analysis section or a competitive advantage is not mentioned in the executive summary, then the variables below should not be coded. If the business plan has both a competitive advantage/analysis section and an executive summary then the variables below should be coded below based on both these sections. If it just states the faults or weaknesses of competitors and not the strengths of the venture, then do not code competitive advantage. The types of competitive advantage that can be coded include:

- [CompAdv_Loc] - location and customer convenience focus. The place where it is located is a competitive advantage. A location competitive advantage refers to the benefits of being close or proximal to something or in a good location.

- [CompAdv_Mgmt] - technical expertise or experience of the team or management

- [CompAdv_Niche] - serve niche markets or special market is a benefit or advantage. This relates to a special market or group of consumers.

- [CompAdv_Price] - price emphasis or low cost is a benefit or advantage

- [CompAdv_Quality] - quality goods and services is a benefit or advantage. This relates to the quality of the service or good providing.

- [CompAdv_Tech] - technologically advanced product or process is a benefit or advantage

3. [FIN] - Where is the venture seeking or received financing from? These areas should be highlighted in the business plan and coded accordingly. Generally this data will be in the financial section. If the type of start up financing is not specifically noted then you do not need to code it. If the type of funding is not mentioned or is not clear or does not fall into one of the categories below, then do not code it.

- [Fin_CarbCred] - The venture earns revenue by selling carbon credits.

- [Fin_CompAward] - The venture indicates that they won a monetary prize in the finals of another business plan or other type of competition. Just participating in the business plan competition does not indicate you one the competition, unless the plan explicitly says so.

- Fin_Don] - The venture earns revenue through donations. Donations could include other in-kind resources like computers.

- [Fin_EI] - The venture earns revenue by selling services or products. The venture is set up so they need to earn income by selling services or products to maintain operations and for their venture to work.

- [Fin_Equity] - The financing will be in equity or stocks.

- [Fin_Govt] - The venture benefits from government financial incentives. 
- [Fin_Grants] - The venture earns revenue through grants.

- [Fin_Invest] - The venture earns revenue through an investment (could be equity or loans).

- [Fin_Loans] - The venture is seeking loans or debt or credit card from any source.

- [Fin_Rec]- The venture already received financing. The amount of the financing already received (but not from the team) should be detailed in EXCEL and casebook. Number should be in thousands (number divided by one thousand)

- [Fin_Sought] - The venture is seeking or needs start-up funding in first stage for the short term (less than 6 months or a year - the key is first stage or start up financing/funding). Use what say in the plan as the financing sought. This is not the revenue goal for the first year, just the money or financing that is needed to start up the venture as indicated in the plan. And it could come from the team. If the venture is a spin off or program of another venture, then the amount the program/spin-off needs in the first stage should be coded. The amount of the financing sought should be detailed in EXCEL and casebook. Number should be reported in the thousands (number divided by one thousand)

- [Fin_Team] - The venture already received financing from founder or team (not future commitments). If the venture is a program or spin-off from a larger company, the financing is coded as team only if the individual founders or teams gave the financing. This only includes actual monetary contributions not time given. The amount of the financing already received from the team should be detailed in EXCEL and casebook. The number should be reported in the thousands (number divided by one thousand). If the amount is in kind (like time of management or volunteers), then code it as 97 .

4. [LEGAL STATUS]. If the business plan indicates the current or proposed legal status of the venture it should be highlighted and coded in NVivo as indicated below. More than one of these types of legal status can be coded. If one venture is starting another venture, then the legal structures of both businesses should be coded.

- [Leg_501c] - The venture is structured or will be structured as a 501c organization

- [Leg_CCorp] - The venture is structured or will be structured as a C-Corporation

- [Leg_Hybrid] - The venture mentions a hybrid legal or organizational structure. This might include a business that discusses both for-profit and nonprofit components.

- [Leg_LLC] - The venture is structured or will be structured as a LLC.

- [Leg_Nonprof] - The venture is structured or will be structured as a nonprofit. If code $501 \mathrm{c}$, then also code nonprofit here.

- [Leg_SCorp] - The venture is structured or will be structured as an SCorporation.

- [Leg_Socbus] - The primary purpose of the venture is social. Often the legal structure might not be indicated in a plan, but by participating in a competition, the plan should have a social purpose. If the venture structure is not indicated, then code it as a social business.

- [Leg_Soleprop] - The venture is set up as a sole proprietorship. 
- [Leg_Spinoff] - The proposed venture is a spin-off or program of another company.

5. [STRATEGY]. Two components of strategy are assessed in the business plan earned income and strategy.

- [Strat_EI] - The number of earned income streams. This is the number of primary products or services being offered that the venture earns revenue for including members dues, licensing fees, services or products. They should be indicated in EXCEL and the casebook and highlighted in NVivo. Not the number of sources of revenue and not bonds or loans.

- [Strat_EIimpt] - The level of importance of the earned income strategy to the social venture in the short term (up to one year). This is measured on the scale below and reported in Excel and the casebook. How important is earned income to the venture's business model and operations.

- $\mathbf{0}$ - Not relevant as no earned income strategy or plans to have one.

- 1 - Not at all important. Business plan says earned income will be pursued in a few years.

- $\mathbf{2}$-Somewhat important. Earned income is only one of multiple types of revenue streams (like grants/donations/loans).

- 3 -Important. Earned income is one of the top revenue streams as per the income statement or written financial section.

- 4 -Very important. Venture has no other sources of revenue besides earned income.

- [Start_EIST] - Is the venture going to earn income in the short term (in the next 6 months to a year)? Can determine this by looking at the financial written section and the income statement to see if earned income is one of the revenue streams in the first year.

- [Strat_Innov] - Is the strategy of the social venture innovative? More than one of the innovation variables can be coded. This variable should be coded by looking at the executive summary.

- [Strat_InMkt] - Market Based innovation as new service or product in the market. Is the venture offering a new service or product in the market that has not been offered by competitors in nearby geographic areas? The focus is on a new service or product that competitors haven't focused on in that specific or nearby geographic area.

- [Strat_InStr] - Strategy based innovation as unique or new type of business model. Does the social venture have an innovative strategy or operations plan to reach an intended population? Has this type of strategy been used before in other ventures?

- [Strat_InTech] - Technology based innovation as innovatively using technology to reach the targeted population. Is technology being used in a new way to reach the target population? Developing a new type of product that uses technology in a new way or develops a new technology. 
- [Strat_InnovSc] - The innovativeness of the strategy of the social venture is based off the previous question. (Strat_Innov) Enter one of the following numerical values into the Excel spreadsheet and the casebook.

- 1 - Not innovative. The venture uses none of the three types of innovation above.

- 2-Somewhat innovative. Only one type of innovation, but not that novel or new.

- $\mathbf{3}$ - Normal. Only 1 type of innovation used, but it is novel or new.

- 4 - Innovative. At least two types of innovation used.

○ 5 -Very innovative. All three types of innovation used (market, strategy and technology).

\section{II. [PARTNER].}

A partnership is defined as an entity with which a social venture collaborates with to pursue their goals or strategies or mission. In a partnership resources are being exchanged. In this analysis, we only code partners if they are called partners in the plan or are indicated as alliances, or collaborators or relationships or close allies.

\section{A. [PART_GENERAL]}

1. [Part_ExSum] - Are partnerships detailed in the Executive Summary as key to strategy or fulfilling their mission? Look for general partners, collaborators, alliances, relationships, or building a network. If more related to organizational structure, then do not include it. The executive summary must explicitly state that the venture will partner with or have an alliance with a certain entity. If there is no Executive Summary - code 99 in EXCEL and casebook. When see the word relationships, make sure they are referring to more formal partnerships.

2. [Part_TOC] - Are partnerships mentioned in the Table of Contents as important to strategy or fulfilling their mission? Look for general partners, collaborators, alliances, relationships, or building a network. It should say we will partner with, "our partners are" or we "collaborate with" or have an "alliance" with or "build a network with". If this not found, then search the business plan for the words partner or collaborate or relationship or alliance when you are done coding to double check. Also look at list of appendices and exhibits if part of the table of contents.

\section{If there is no Table of Contents - code 99 in EXCEL and casebook.}

B. [PART_RESOURCE] - What type of resources are gained through the partnerships that are identified in Part_ExSum, Part_TOC, or Part_Type? We are interested in resources flowing to the social venture. We are interested in resources that flow to the social venture (in the business plan) from their partners. These resources should be highlighted and coded according to the categories below. Multiple resources may present within a single business plan. These are resources that are specifically mentioned that are exchanged between partners - not inferred. 
- [Res_Access] - Partner provides access to a particular market or community to offer services/products

- [Res_AdvSup] - Partner offers advice or support (particularly states this). This would not include the board of directors or advisors.

- [Res_DesDvpt] - Partner assists with design/development of a product/service.

- [Res_DisSale] - Partner helps distribute or sell a product/service.

- [Res_Donations] - Partner provides donations to the venture

- [Res_Endorse] - Partner endorses a product/service. The partner says it is a good service or product.

- [Res_Grant] - Partner provides grants to the venture.

- [Res_Human Capital] - Partner provides staff or people to help the venture. Volunteers are coded separately.

- [Res_Input] - Partner provides physical input of a product/service like milk for a venture that makes ice cream.

- [Res_Invest] - Partner invests financial resources into the venture. This is generally a stake or share in the business or piece of equity in the venture. Should just be for equity investments.

- [Res_Knlge] - Partner provides knowledge or insight to assist social venture. Generally the plan will specifically say that they are learning from the expertise or knowledge of partner.

- [Res_Loan] - The partner provides a loan to the venture.

- [Res_Maint] - Partner assists with maintenance of a service/product.

- [Res_Materials] - Partner provides access to materials.

- [Res_Mktg] - Partner assists with advertising of a service/product

- [Res_Monetary] - Partner provides monetary or financial assistance - loans, grants, donations, investments. Only if this entity is referred to as a partner in the business plan. In some cases, business plans do not indicate what type of monetary support they get from their partners. If this is the case, this should be coded. In addition if specific types of monetary support are coded (loans, grants, donations, investments), then this variable should also be coded.

- [Res_Patent] - Partner provides access to a patent or license

- [Res_Space] - Partner provides access to space

- [Res_TestProd] - Partners assist with testing of a product, prototype or with a pilot project

- [Res_Vol] - Partner provides access to volunteers. These volunteers are resources that are gained through partnerships. If code this variable do not need to code [Res_Human Capital]

C. [PART_TYPE] - What type of entity is the venture partnering with in order to meet their goals or strategy? These types of partners should be highlighted and coded according to the categories below. The plan should say we will partner with, "our partners are" or we "collaborate with" or we have an "alliance with" or "work closely with" or have "close relationship with" or close "allies" or "building or creating a network". Marketing relationships SHOULD NOT be coded. If a section is called partners and lists entities in that section then they are partners. If this not 
found after you are done coding the plan, then search the business plan for the words partner or collaborate or alliance to double check. If a business plan makes reference to receiving a particular resource from a partner, but not the type of partner, just code the resource.

- [Part_Client] - Partner with client

- [Part_Comty] - Partner with community as specifically stated in the business plan.

- [Part_Corp] - Partner with corporation

- [Part_CorpSup] - Partner with corporate supplier

- [Part_Fin] - Partner with financial institution or bank

- [Part_Govt] - Partner with government (not include public schools)

- [Part Indv] - Partner with individual. Does not include volunteers.

- [Part_Mfi] - Partner with microfinance institution

- [Part_NGO] - Partner with a non-governmental organization, or nonprofit partner, or social venture, community organizations, libraries. Do not code for churches or schools here.

- [Part_Relgn] - Partner with religious institution like a church, missionary

- [Part_School] - Partner primary or secondary school

- [Part_Uni] - Partner a university or higher academic institution

III. [VALUE] - What type of value does the social venture create or enable? This is coded only if it is in certain sections of the business plan. First focus on identifying the value created in the social (environmental) impact section and the executive

summary. If there is no social impact or executive summary section, then look at the competitive analysis section. If the social impact OR the executive summary section is present, then all the types of value created (economic, social and environmental) should be coded by looking at these sections and not the competitive analysis section.

1. [EcV] - Monetary benefit for clients or beneficiaries. You can code for multiple types of economic value.

- [EcV_ClientEarn] - Venture enables client or beneficiary to earn money or get/improve access to financial resources. Bringing customers is earning more money. This does not include ROI to shareholders/equity investors. ROI is coded as a separate variable [EcV_ROI]

- [EcV_ClientProd] - Venture improves the productivity of client or beneficiary. Productivity is making a business run more efficiently. It is not related to convenience.

- [EcV_CostSav] -Venture product or service results in cost savings for client. The plan must state that the venture will help reduce costs or save costs for the client.

- [EcV_Donate] - For-profit social venture donates a portion of their profits to a social cause or if the venture is a nonprofit and donates part of revenue for another venture that or provides a pro-bono service is not their primary cause then this can be checked. 
- [EcV_EmployEd] - Venture supports the further education of their employees by providing financial support - tuition assistance

- [EcV_EmployFin] - Venture provides financial assistance for employees like loans.

- $[\mathbf{E c V}$ _Train] - Venture provides training to their employees for career advancement.

- $\quad$ EcV_Jobs] - Venture details the jobs it creates - if they talk about it in the business plan or if creating jobs for the target population is directly indicated as part of the social mission or goals of the venture.

- [EcV_ROI] - Detail of the return on investment or equity provided by the venture

- [EcV_SupInt] - Integrate local community or beneficiary in venture supply chain

2. [EnvtV] - General environmental benefit produced by a venture. You can code for multiple types of environmental value. If the type of environmental value is not listed, then code it under [Envt V].

- [EnvtV_Commute] - Venture promote policies that support employee commuting

- [EnvtV_EcoFriendly] - Venture develops or sells a produce or service that is environmentally friendly.

- [EnvtV_Energy] - Venture reduces the consumption of energy

- [EnvtV_GreenGas] - Venture reduces greenhouse gas emissions and global warming

- [EnvtV_Recycle] - Venture promotes recycling or uses reusable materials or products

- [EnvtV_RecyProd] - Ventures develops or manufactures a product from recycled materials

3. [SocV] - Social value produced by a venture. You can code for multiple types of social value.

- [SocV_CmtyDvpt] - Social value in the area of community development as indicated in the business plan.

- [SocV_Ed] - Social value in the area of education improvement

- [SocV_Health] - Social value in the area of health improvement

- [SocV_Integrity] - Social value as venture practices integrity as stated in the business plan.

- [SocV_QuaLife] - Venture improves the quality of life or makes a difference in the life or betters the life as specifically stated in the business plan.

- $\quad$ [SocV_RespBus] - Venture seeks to use or facilitate the use of responsible business practices as specifically stated in the business plan.

- [SocV_SROI] - Social return on investment or double/triple bottom line as value produced. Only code for SROI if the business plan specifically mentions SROI.

- [Soc_UNGC] - Venture discusses how it meets UN Global Compact guidelines

- [Soc_Water] - Venture improves water quality. 
Appendix 10: Survey Instrument

Social Venture Survey

1. Instructions - Venture Status

The survey seeks to better understand the role of partnerships in social ventures. We hope the results from this survey will assist academics, practitioners and policy makers in better understanding social ventures.

This survey refers to the venture for which you submitted a business plan to a social venture business plan competition.

When filling out this survey, please read each statement carefully and answer all questions with the option that best describes your opinion. Please note that there is no right or wrong answer. Please complete as much of the survey as possible. The survey will take approximately 8-10 minutes to complete.

Your participation in this survey is voluntary. There are no foreseeable risks or benefits to you for participating in this study. If you have questions you may contact Moriah Meyskens at 305-302-4201/moriah.meyskens@fiu.edu or Karen Paul at 305-348-6881/karen.paul@business.fiu.edu at Florida International University (FIU) and we will answer your questions. If you have questions about your rights or treatment as a volunteer in this research survey, please call Dr. Patricia Price at 305-348-2618 or 305-348-2494 at Florida International University. Dr. Price is the Chair of the Institutional Review Board at FIU.

Thank you for taking the time to fill out this survey. The results are anonymous and strictly confidential.

\section{Name of the social venture as you submitted it to the business plan} competition.

2. Did you actually intend to launch the social venture (that you submitted to the business plan competition)?

I did not plan to ever launch the social venture. I did plan to launch the social venture.

Comments

\section{Did you launch the venture?}

Yes No

When?

4. If your venture never launched, why did it not launch or start?

Not able to secure funding

Started school

Never intended to be launched

Started another venture

Other (please specify)

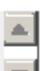




\section{Social Venture Survey}

5. If your venture never launched, are you still in the process of developing it?

$\square$ Yes

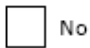

Comments

6. When did you stop developing your venture? (year)

7. If your venture is no longer operating, why is it no longer operating?

$\square$ Merged with another company

$\square$ Started school

Not able to secure funding

Voluntarily closed down

Started another venture

Other (please specify)

8. Is your venture currently operating or in the process of being developed?

$\square$ Yes

$\square$ No 


\section{Social Venture Survey}

\section{Partnerships, Achievements, Value Created, \& Strategy}

Below are a few questions regarding the social venture for which you submitted a business plan to a social venture business plan competition. Please keep this social venture in mind when you answer the questions below.

1. To what extent are partnerships with other organizations or entities important to the achievement of your social venture's goals? Partnerships are alliances or collaborations with other entities that faciliate the achievement of venture goals. In partnerships resources are generally exchanged.

In order to reach or achieve venture goals partnerships with....

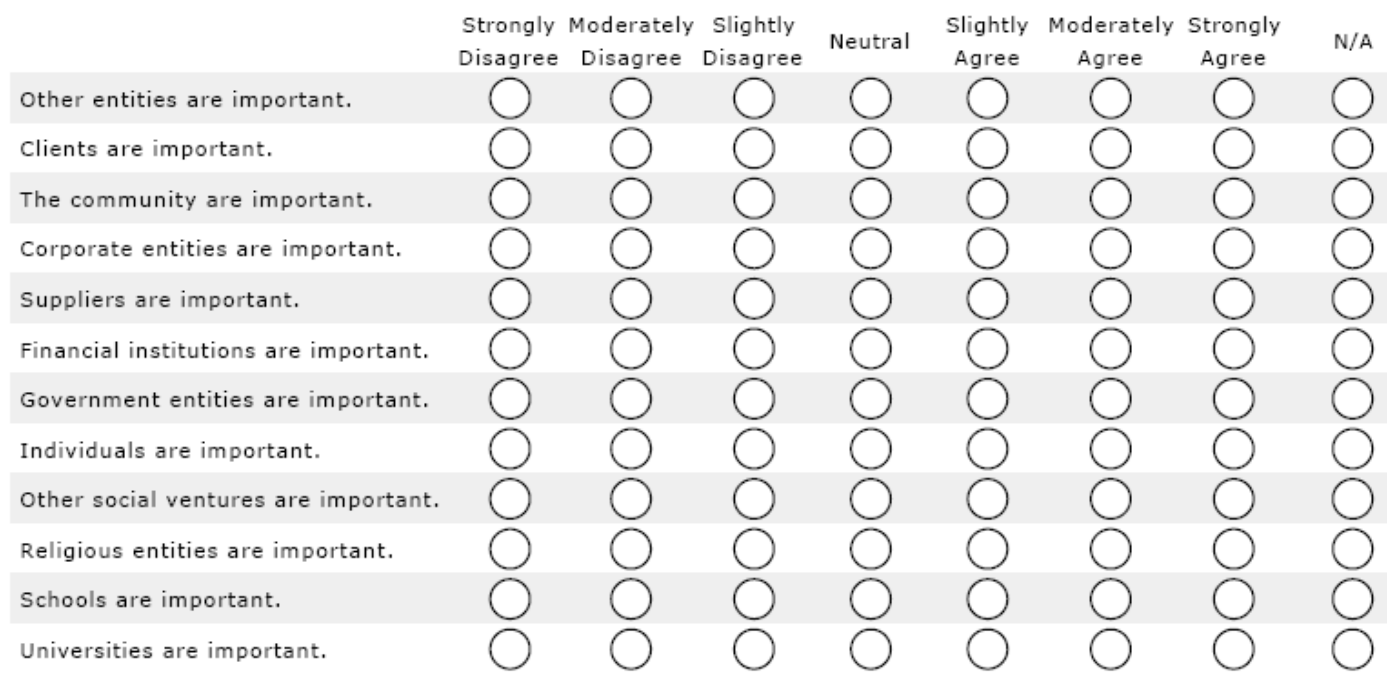

2. What are the most important resources (top three) your social venture gains through partnerships? Resources refer to physical, human, financial and social capital items that are gained through partnerships. These resources can be both tangible (ex. space, volunteers, money, referrals, assistance with distribution or testing a product) and intangible (ex. knowledge, access to a market, endorsement). 


\section{Social Venture Survey}

3. Please indicate if your social venture has achieved any of these activities:

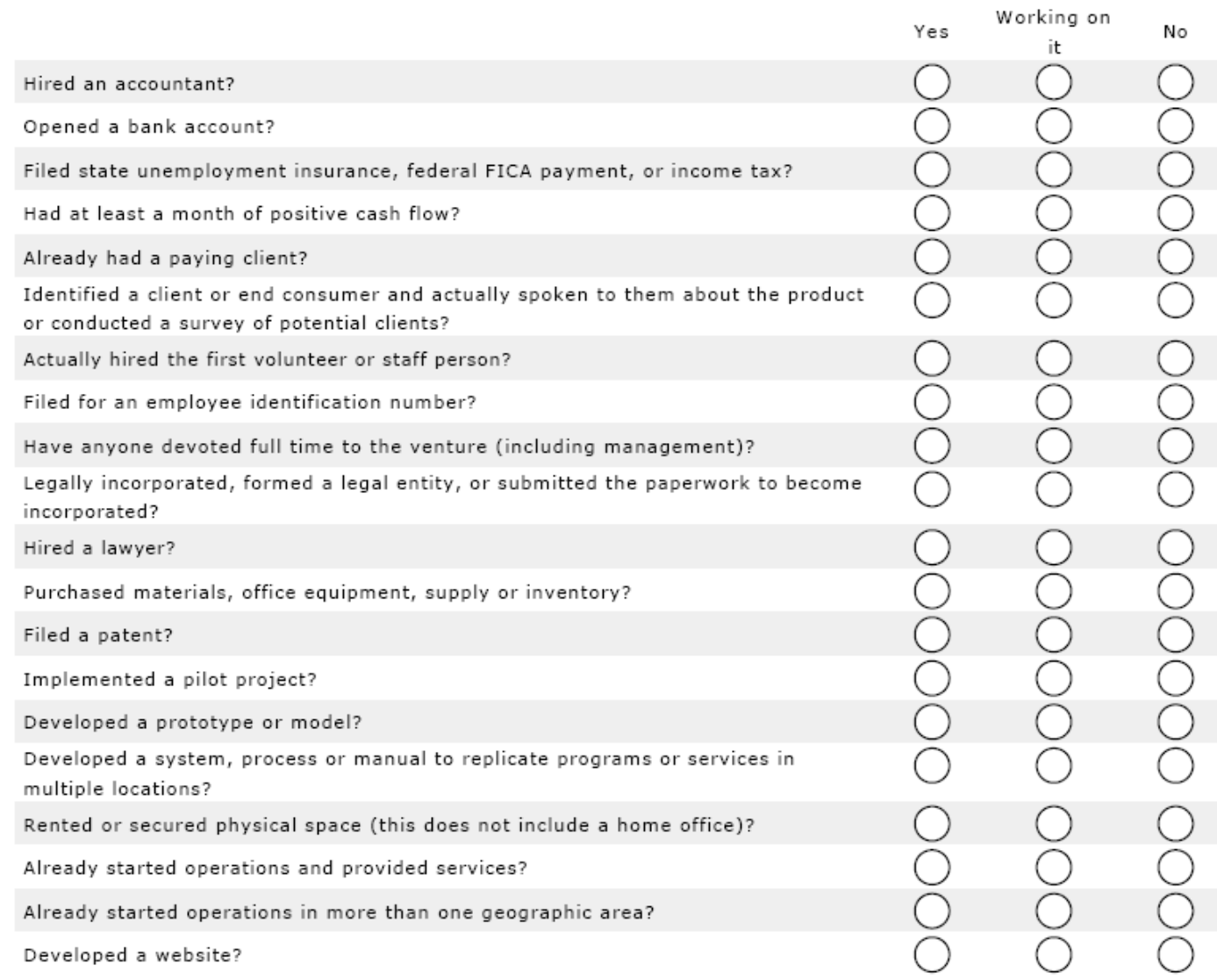




\section{Social Venture Survey}

\section{Value Creation}

\section{To what extent do you agree that the social venture is creating value now}

or plans to create value in the future by:

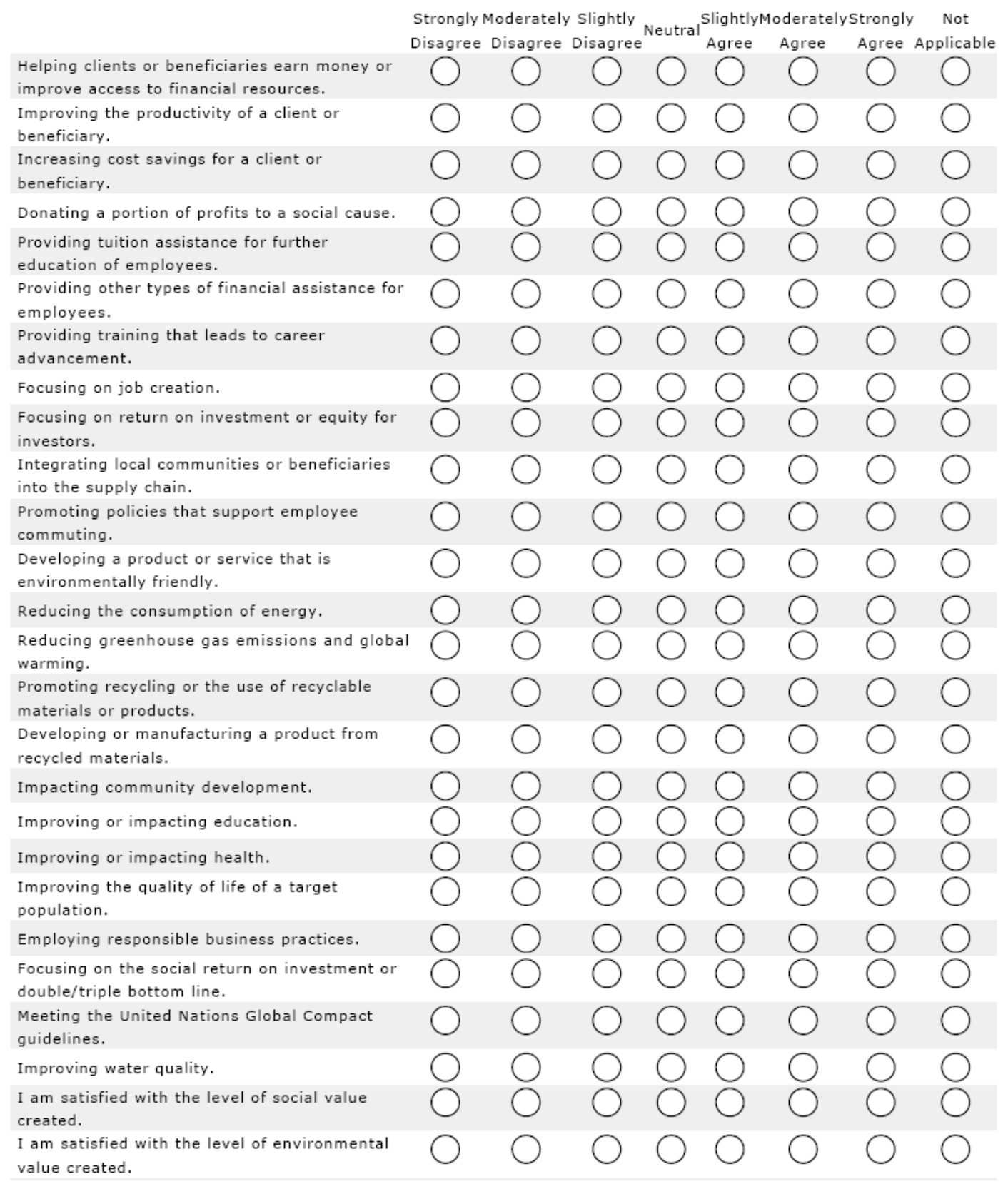




\section{Social Venture Survey}

I am satisfied with the level of economic value

created.

5. Which of the following best describes the goals of your venture? (choose one)

For profit - primarily achieving economic goals

For profit - primarily achieving social goals

For profit - equally emphasizing social and

economic goals

Other (please specify)
Not for profit serving a social mission

Non-profit / For-profit hybrid structure

畨

6. Businesses may measure their performance as the ability to generate economic, societal, and/or environmental value. In other words a business may measure its performance by profit, impact on people, and/or impact on the environment.

Please allocate 100 percentage points across these categories as it pertains to how you measure the performance of your business. For example, a business may measure performance as $80 \%$ profit, $10 \%$ societal, and $10 \%$ environment.

$\%$ profit

$\%$ societal

$\%$ environment

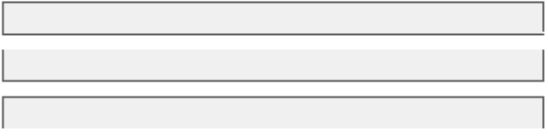




\section{Social Venture Survey}

7. How important is your earned income strategy to the social venture? Earned income refers to revenues earned through the sale of products or services. Please choose one of the items below

Not relevant as no earned income strategy or plans to have one.

Not at all important. Earned income will be pursued in a few years.

Somewhat important. Earned income is only one of multiple types of revenue streams (like grants/donations/loans).

Important. Earned income is one of the top revenue streams.

Very important. Earned income is the only source of revenue.

Comments

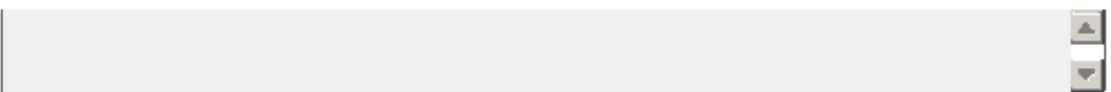

8. If earned income is your only or primary source of revenue, please describe the type of earned income in your strategy (i.e. please describe the products and/or services from which you derive revenue).

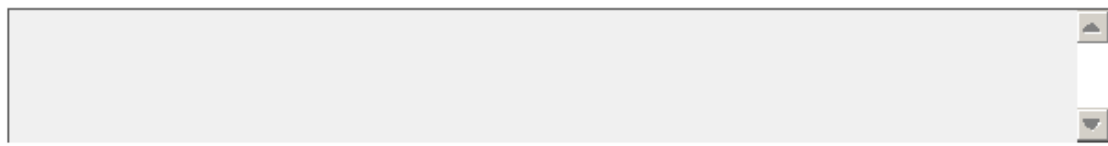

\section{Venture Strategy.}

The social venture offers a service or product that

has not been offered by competitors in nearby geographic areas.

I am satisfied with the level of earned income achieved.

The social venture uses a new technology or technology in a new way to reach the target population.

Strongly Moderately Slightly Disagree Disagree Disagree
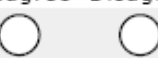

Comments (regarding strategy) $\triangle$

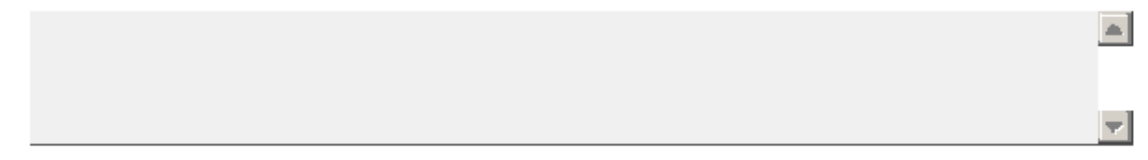




\section{Social Venture Survey}

10. Please indicate the total revenue from all sources (including earned income, philanthropic donations, grants, etc.) and just revenue from earned income (revenues earned through the sale of products or services) for THIS YEAR. Also indicate the number of employees, independent contractors and volunteers in your venture expected for THIS YEAR.
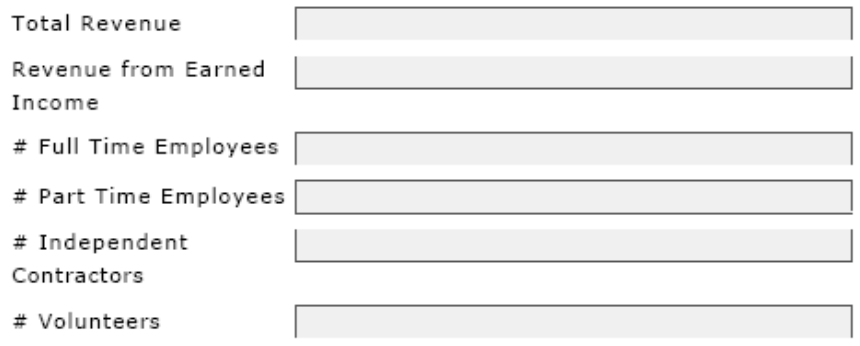

11. Please indicate the total revenue from all sources (including earned income, philanthropic donations, grants, etc.) and revenue from earned income (revenues earned through the sale of products or services) for NEXT YEAR. Also indicate the number of employees, independent contractors and volunteers in your venture expected for NEXT YEAR.

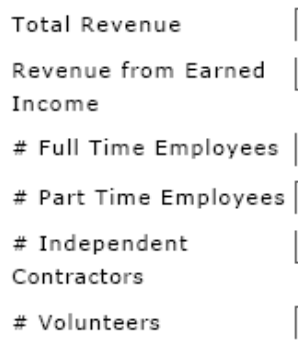




\section{Social Venture Survey}

\section{Business Competition \& Demographic Characteristics}

This section asks you some questions regarding your social venture as well as some general demographic characteristics.

When answering the following questions, please refer to the same social venture as in the previous two sections (for which you submitted a business plan to a social venture business plan competition).

\section{Participation Details}

How many competitions has your social venture participated in?

Did you win one of the competitions? If not, how far did you get?

How much money did you win or receive (if any -

Please detail)?

What other non-monetary

prizes (like free

accounting services, legal

advice, etc.) did you

receive from the business

plan competition?

2. In your opinion, what was the primary purpose of the business plan competition in which you participated?

Launch a business

Education

Marketing

Build

Alumni/Community Network

Other (please specify)

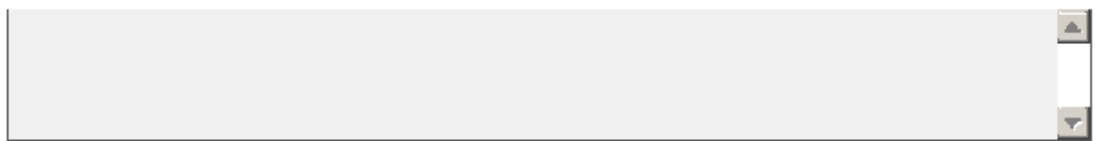

3. Did you originally write this business plan for one of your courses?

$\lceil$ Yes No

If Yes, which course? 


\section{Social Venture Survey}

4. Is anyone in your family an entrepreneur?

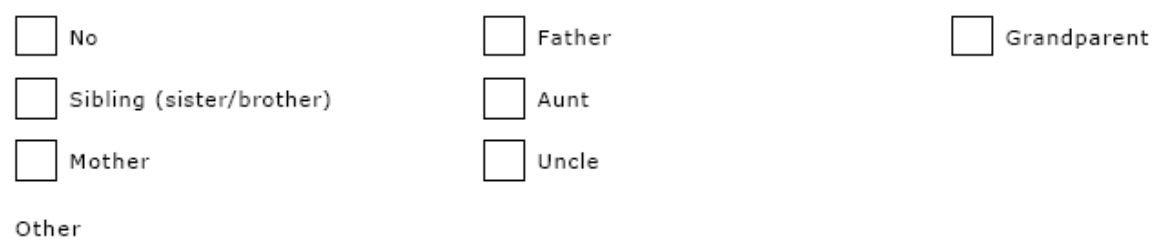

\section{Highest Completed Degree}

$\square$ High School

\section{Education}

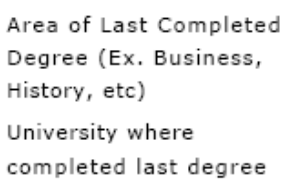

7. How many university level entrepreneurship courses did you take?

Non

8. How many social ventures have you founded?
$\square 0$
$\square 1$
$\square 2$
3 or more

9. How many total ventures (social and non-social) have you founded?
Do
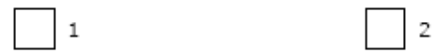
3 or more

10. Number of years of working experience
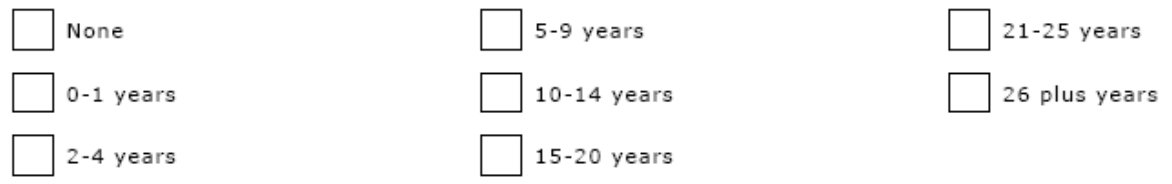
Social Venture Survey

11. Where are you working currently?

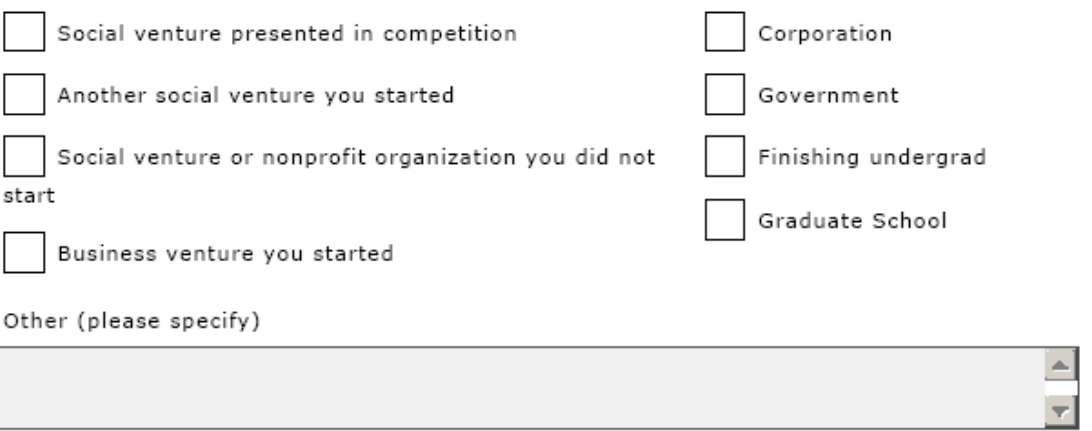

12. Please state your current job title

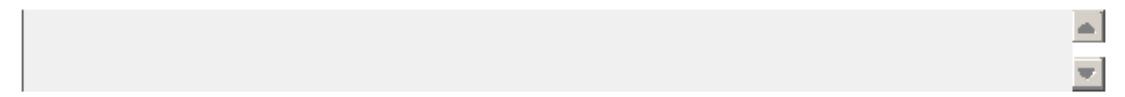

\section{In which age category are you?}

$\begin{array}{lll}\square \text { Under 18 } & \square_{35-44} \\ \square_{18-24} & \square^{45-54} & \square 75+74 \\ \square_{25-34} & \square{ }^{55-64} & \end{array}$

14. Sex

Male Female

15. What is your main racial or ethnic heritage?
Caucasian
African-American
Hispanic
Asian

Other (please specify)

\section{General Information (optional)}

Name

Email

Thank you for taking the time to complete this survey! The results from this survey will assist academics, practitioners and policy makers in better understanding social ventures.

The results are anonymous and strictly confidential.

If you have any questions, please contact Moriah Meyskens at moriah.meyskens@fiu.edu. 


\section{Appendix 11: Survey Request Email}

Subject: Social Venture Business Plan Competition Survey Follow-up

Dear NAME,

I wanted to follow-up with you regarding the social venture business plan that you submitted to the Social venture business plan competition at SPONSOR/UNIVERSITY.

My dissertation research is on social ventures. Particularly I am interested in the role of partnerships or strategic alliances in the achievement of social venture goals and development.

As part of my research, I am conducting a brief follow-up survey of individuals who participated in social venture business plan competitions across the United States. The survey should only take 8-10 minutes to complete. Your participation would be extremely appreciated and useful for my dissertation research and increase our understanding of the field.

The survey can be accessed at http://www.surveymonkey.com/s/MTLL2FW

Thank you so much for helping me by completing this survey!

Please contact me if you have any questions.

Kind regards,

Moriah

Moriah Meyskens

PhD Candidate

Florida International University

Department of International Business \& Management

Visiting Scholar Babson College

mmeyskens@gmail.com

(305) 302-4201 
VITA

\section{MORIAH AURORA MEYSKENS}

\section{EDUCATION}

Florida International University, Miami, FL

2010

Ph.D. Candidate in Business Administration

Visiting Scholar, Babson College, 2009-2010

New York University, New York, NY

Master of Business Administration, Management and Entrepreneurship

2005

University of California, Los Angeles, Los Angeles, CA

1998

Bachelor of Arts, Economics and Latin American Studies

\section{PUBLICATIONS AND PRESENTATIONS}

Meyskens, M., Carsrud, A., \& Cardozo, R. Forthcoming. The symbiosis of entities in the social engagement network: The role of social ventures. Entrepreneurship \& Regional Development.

Meyskens, M. \& Paul, K. Forthcoming. The evolution of corporate social reporting practices in Mexico. Journal of Business Ethics

Meyskens, M., Robb-Post, C., Stamp, J., Carsrud, A. \& Reynolds, P. 2010. Social ventures from a resource-based perspective: An exploratory study assessing global Ashoka Fellows. Entrepreneurship Theory \& Practice, 34(4): 661-680.

Meyskens, M., Von Glinow, MA, Werther, W.B., \& Clarke, L. 2009. The paradox of international talent: Alternative forms of international assignments. International Journal of Human Resource Management, 20(6): 1439-1450.

Meyskens, M. \& Carsrud, A. 2009. The role of partnerships in early stage ventures: An exploratory study. CCSBE, Toronto.

Meyskens, M. 2009. Do social venture business plan competitions make a difference? New York University Stern Social Entrepreneurship Conference, New York.

Meyskens, M. 2009. The role of partnerships in early stage green-tech ventures. New York University Stern Social Entrepreneurship Conference, New York.

Schneper, W., Meyskens, M.A., Solemani, A., Celos, S.,Hei, W. \& Leartsurawat, W. 2009. Organizational drivers of corporate social responsibility: Disentangling substance from rhetoric. Academy of Management, Chicago.

Meyskens, M.A. \& McKague, K. 2009. Poverty alleviation, ecosystems, and business: Challenges and opportunities for a research agenda. Co-lead PDW. Academy of Management, Chicago. 
Meyskens, M.A., Kiyatkin, L. \& Pfarrer, M. 2009. Content analysis in organizational research: Techniques and application. Co-lead PDW. Academy of Management, Chicago.

Von Glinow, MA., Clarke, L. \& Meyskens, M. 2008. Polycontextuality and research methodology: Issues and illustrations. Academy of International Business, Milan, Italy.

Meyskens, M.A. 2008. The role of NGO partnerships in creating a competitive advantage for firms. The Role of Nongovernmental Organizations (NGOs) in the Business Government - Society Interface, Paris, France.

Wankel, C. (Ed.) 2008. Encyclopedia of business in today's world. Vol 1. Argentina Entry (Meyskens, M). Sage Publications 69-70

\section{ACADEMIC ACTIVITIES}

- Reviewer: Small Business Economics (2010), Journal of Small Business Management (2009), Entrepreneurship Theory \& Practice (2009), Journal of Business Ethics (2009 \& 2010), Academy of International Business (2009 \& 2010), Academy of Management (2008, 2009, 2010), Strategic Management Society, USÄSBE (2008)

- Judge: William James Foundation Business Plan Competition (2008, 2009 \& 2010)

- Member: Academy of Management \& Academy of International Business (2006Present), American Sociological Association (2009)

- Advisor: FIU Microfinance Initiative (2007-2009)

\section{PROFESSIONAL EXPERIENCE}

Florida International University, Miami, Florida 2007-2009 Instructor, College of Business Administration

Florida International University, Miami, Florida 2007-2010 Research Assistant, Mary Ann Von Glinow, Kenneth Lipartito, Karen Paul,

SFLUM, Miami, Florida

2005-2007

Development Director, Microenterprise and youth development non-profit entity

ACCION New York, New York, NY

2003-2004

Lending Team Manager, Premier microfinance organization

TA McKay, New York, NY

2001-2003

Fund Administrator, Boutique hedge fund specializing in distressed securities

Proxy Monitor, New York, NY $2000-2001$ Global Associate Analyst \& Operations Manager, Corporate governance

Salomon Smith Barney, New York, NY 1998 - 1999 Research Assistant, Latin American Equity Research, Cement \& Construction Sector 